\title{
17. GEOCHEMISTRY AND PETROLOGY OF EVAPORITES CORED FKOM A DEEP-SEA DIAPIR AT SITE 546 OFFSHORE MOROCCO ${ }^{1}$
}

\author{
William T. Holser, Department of Geology, University of Oregon \\ Eric S. Saltzman, Rosenstiel School of Marine and Atmospheric Science, University of Miami \\ and \\ Douglas G. Brookins, Department of Geology, University of New Mexico ${ }^{2}$
}

\begin{abstract}
At Site 546, below the Mazagan Escarpment at a water depth of $4 \mathrm{~km}, 36 \mathrm{~m}$ of salt rock was cored from the top of one of a field of salt domes. The core was studied by thin section and a variety of geochemical procedures. The salt rock contains 0.1 to $3 \%$ carnallite and lesser amounts of sylvite and polyhalite, which with the corresponding high level of bromide place it within the potash evaporite facies. The bromide profile is of a dominantly marine evaporite deposited in moderately shallow brine which, however, was not repeatedly desiccated. A mineralogical argument suggests that the brine surface was not below sea level.

An average of about $5 \%$ clastics, with dispersed anhydrite, darken the salt rock to deep shades of red, brown, and gray green. Most of the included materials are in highly deformed boudins or dispersions in the salt rock that has also undergone cataclasis in a subsequent, probably tectonic, deformation. The salt rock is slightly deficient in anhydrite, and the usual separate beds and laminae of anhydrite are virtually absent.

Stable isotope ratios of sulfur and oxygen in the sulfate are clearly derived from sea water of Permian to Scythian age, in contrast to the late Triassic or Early Jurassic age of evaporites onshore in Morocco and Portugal and the corresponding evaporites offshore Maritime Canada. In contrast to those evaporites off the axis of Atlantic rifting, the salt at Site 546 may have been deposited in a very early central rift fed by marine waters from Tethys through the Gibraltar or South Atlas fracture zones.
\end{abstract}

\section{INTRODUCTION}

The top of an intrusive structure that reaches nearly to the sea floor at the base of the Mazagan Escarpment, $125 \mathrm{~km}$ northwest of Casablanca, Morocco was cored at Site 546. This is one of a belt of diapirs that extends along the eastern border from offshore Portugal intermittently to offshore Senegal. A corresponding belt is found along parts of the western margin of the Atlantic (Fig. 1). In the geophysical reconnaissance, the features of this diapir appeared to be those of a salt dome, and sedimentary basins on the nearby Moroccan coast include salt beds, anticlines, and domes. Together these evaporites were thought to represent the initial marine deposition in the opening of the Atlantic Rift. The diapir at Site 546 was of particular interest as the first such evaporite to be cored in the offshore Atlantic. Before drilling there was some doubt as to whether or not the diapir was a salt dome, for a similar structure $15 \mathrm{~km}$ to the east had yielded granitic fragments from piston coring and a leucocratic gneiss in the core at Site 544.

Hole 546 was sited near the top and near the western end of a seismic and topographic structural high at least $4 \mathrm{~km}$ wide (water depth $3958 \mathrm{~m}$ ). At $156.5 \mathrm{~m}$ beneath seafloor, underlying a clastic section with oldest sediments dated to Late Jurassic, the drill entered salt rock

\footnotetext{
${ }^{1}$ Hinz, K., Winterer, E. L., et al., Init. Repts. DSDP, 79: Washington (U.S. Govt. Printing Office).

2 Addresses: (Holser) Department of Geology, University of Oregon, Eugene, OR 97403 ; (Saltzman) MGG, Rosenstiel School of Marine and Atmospheric Science, University of Miami, 4600 Rickenbacker Causeway, Miami, FL 33149; (Brookins) Department of Geology, University of New Mexico, Albuquerque, NM 87131.
}

and cored evaporites to a total depth of $192 \mathrm{~m}$. Geochemical and petrological studies of this evaporite core are the basis for this report. During July-August, 1982, W. T. Holser and Gail Peretsman also sampled evaporites in outcrops and cores in several Mesozoic sedimentary basins onshore in Morocco and Portugal; correlative geochemical studies of these materials are now in progress and will be reported elsewhere.

The objectives of the geochemical and petrological studies were to provide information on (1) the age of evaporite deposition, which presumably followed shortly after initial rifting; (2) the relative importance of marine and nonmarine contributions to the chemistry of the evaporites in a paleogeographic situation where either could have been dominant; and (3) whether the evaporite was deposited in relatively deep water or in a shallow playa or sabkha milieu (either at sea level or subsea level).

\section{GEOLOGIC SETTING}

The diapir sampled at Site 546 is part of a thick and extensive field of evaporite rocks bordering the North Atlantic (Fig. 1). Although all are generally considered to be of Triassic-Jurassic age and consequent in one way or another upon rifting of the Atlantic, their relative ages and structural relations are not well known. According to Hinz, Winterer, et al. (1982; site chapter, this volume) the salt at this locality was expressed from a depth (at its base) of about $7.5 \mathrm{~km}$ below sea level ( $3.5 \mathrm{~km}$ below seafloor). It overlies thinned continental crust possibly contaminated by basaltic intrusions, intermediate between the clearly oceanic crust with magnetic anoma- 


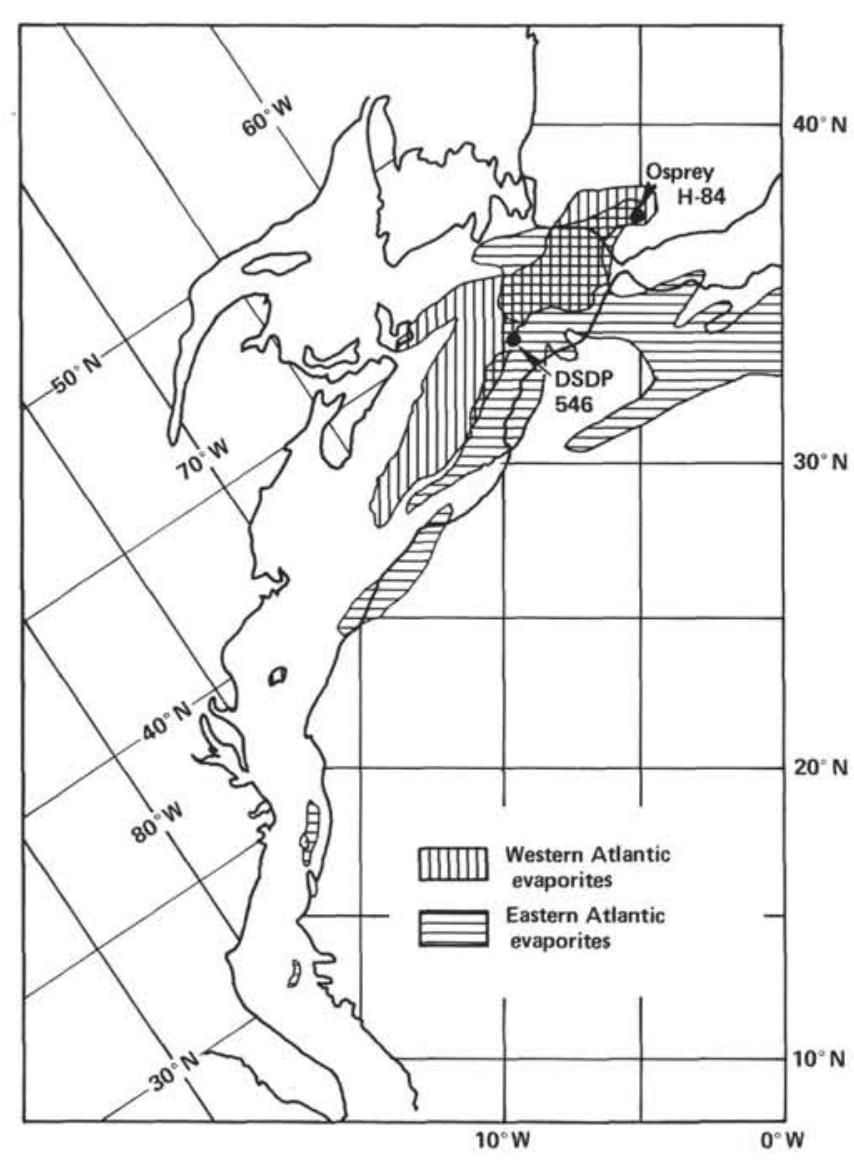

Figure 1. Salt basins of the North Atlantic projected on predrift geography (except for Spain, shown in its present position relative to Africa). Evaporite rock geochemistry has been studied in the two holes shown: in the western Atlantic, Osprey H-84 (Jansa et al., 1980); in the eastern Atlantic, DSDP Site 546 (this paper). Pangea fit after Wissman and Roeser (1982); salt basins after Salvan (1974), Jansa et al. (1980), and Wissman and Roeser (1982).

lies that lies $40 \mathrm{~km}$ to the west and the normal continental crust that underlies the Mazagan Plateau $25 \mathrm{~km}$ to the east (Hinz, Dostman, et al., 1982; Roeser, 1982; Channell, this volume). The belt of diapiric structures in which Site 546 lies is contiguous with near and onshore evaporite basins. From north to south, they are the Rharb (and Khemmiset) Basin, the Berrechid Basin, the Doukkala Basin, the Essaouira (or Agadir) Basin, and the northern end of the Tarfaya Basin (Salvan, 1974; Lancelot and Winterer, 1980). The diapiric zone appears to continue northward under the Rif-Betic olistostromes off Gibraltar (Malod, 1980), and it may have originally been continuous with the Flemish and Lusitania basins north of the Gibraltar fracture zone (Ribeiro et al., 1972; Haworth and Keen, 1979; Jansa et al., 1980). Evaporites of at least approximately the same age continue eastward across the African craton of Morocco (Salvan, 1974), Algeria, and Tunisia (Tortochaux, 1968; Kulke, 1978), but the relations of age and structural origin between these evaporites and those of the offshore basins need to be clarified. Not all the diapirs need be salt rock. In the western Atlantic, the evaporite belt lies entirely offshore (mainly Nova Scotia) where it has been directly described from cuttings in one well (Jansa et al., 1980). The relations of the morphology and sedimentation on the two sides of the Atlantic has been described repeatedly (e.g., Evans, 1978) and are reviewed in detail recently by Jansa and Wiedmann (1982) and Hay et al. (1982).

The total area underlain by the North Atlantic evaporites, including the coastal basins of Morocco and Portugal listed above but not those farther east, is about $450 \times 10^{3} \mathrm{~km}^{2}$. The thickness of the evaporites is more difficult to ascertain. On the landward edges, $800 \mathrm{~m}$ was found in the Scotian Basin (Jansa and Wiedmann, 1982) and, in the Essaouria Basin, wells that only partially penetrated the Triassic section intersected as much as $2000 \mathrm{~m}$ of salt, but averaged only $100-300 \mathrm{~m}$. Cross sections, based mainly on geophysics, indicate around $4 \mathrm{~km}$ of "salt" in the axes of many of the evaporite basins (Jansa and Wiedmann, 1982, figs. 7-11). Although these cross sections are diagrammatic, such thickness does not seem excessive in view of the extensive diapirism that has developed. A thickness of about $2 \mathrm{~km}$ means a total volume of about $10^{6} \mathrm{~km}^{3}$ of evaporite rocks in the North Atlantic.

Similarly, little information is available on the evaporite facies developed in the North Atlantic basins. Where observed onshore in the Essaouira and Lusitania basin margins, a rough progression toward the basin can be seen from cyclic alternations of gypsum and red siltstones to anticlines dominated by salt but displaying many red beds and some gypsum on outcrops to diapirs of salt rock colored by red beds. As discussed below, all salt rock samples contain a few percent anhydrite, but actual beds of anhydrite or gypsum seem to be completely absent except at the shoreline. Certainly the amount of $\mathrm{CaSO}_{4}$ in these evaporite basins does not nearly approach the mean of $25 \%$ found in all evaporite basins worldwide (Holser et al., 1980). Furthermore, carbonates commonly found near the base of most evaporite sections have never been observed in the North Atlantic evaporites. Potash facies minerals are extensively developed only in the Khemmiset (Rharb) Basin (Amadé, 1965) and less developed in the Berrechid Basin (W.T.H.) as well as at Site 546 (described below).

The red bed association in both the Scotian Basin and onshore Morocco suggests a continental playa, a bordering sabkha, or at least a shallow marine deposition milieu. Whether this also applies to the thicker evaporites of the basinal axes is questionable.

The age of North Atlantic evaporites is bracketed by metamorphosed sediments as young as Carboniferous that underlie some sections and marine limestones of Sinemurian-Pliensbachian age that overlie most red bed sections on both sides of the Atlantic (Jansa and Wiedmann, 1982). Palynology dates salt rock from the Scotian Basin as Rhaetian to early Sinemurian (Barss et al., 1979); onshore Morocco, radiometric dating of intercalated basalt flows ranges in age from 180 to $250 \mathrm{Ma}$ (mean $197 \mathrm{Ma}=$ Rhaetian) (Van Houten, 1977; Manspeizer et al.; 1978; Westphal et al., 1979). However, Jansa and Wiedmann (1982) have pointed out that for the Scotian Basin the salt in the diapiric belt farther off- 
shore could be older than the salt drilled on the shoreward upper flank and the same could be suggested for Morocco. The evaporite sections of both the Essaouira and Scotian basins have widths of about $200 \mathrm{~km}$ which at a spreading rate of $1 \mathrm{~cm} / \mathrm{yr}$. could have allowed a depositional time span of $20 \mathrm{Ma}$, i.e., about equivalent to the Rhaetian through Sinemurian interval (Armstrong, 1978).

\section{SAMPLING AND DESCRIPTION OF THE EVAPORITE ROCKS}

The core was prepared for examination by smoothing a 1 to $2 \mathrm{~cm}$ chord with steel files. This treatment prevented damage to any fluid inclusions resulting from the excessive heat and/or oil bath following diamond saw slicing. In the filing process, a first cut which was somewhat nonrepresentational due to the initially uneven surface, was saved; a second cut was taken as a channel sample in 20 to $50 \mathrm{~cm}$ lengths for chemical analysis. Core 546-21 was too strongly dissolved to allow filing, thus was only examined directly and spot sampled. The smoothed core chord was lightly brushed with mineral oil to improve surface optics, and the whole length studied by hand lens. After examination of the core, spot samples were taken for X-ray diffraction, thin section, radiometric age, stable isotope, and other geochemical analyses.

Detailed descriptions of each core section, with lithologic logs, are given in the Appendix and summarized in Figure 2. These descriptions are based on the visual examination and some details may not be accurate when compared to the analytical data. In particular, the estimates of potash and clay mineral contents are somewhat higher than those determined by analysis. In the text below, the visual descriptions are supplemented by study of ten thin sections of typical or critical rock types at locations shown in the Appendix. Potash mineralization is separately described below.

Salt rock is the dominant component of the core (Pl. 1, Fig. 1). The color varies from clear, colorless, gray, or green to pale pink, orange, and light to dark red brown. These color variations are described and diagrammed in the Appendix. Most of the coloration is due to bands, breccias, and dispersions of claystone or siltstone, much of it stained reddish brown by hematite. Typical salt rock shows 2 to $6 \mathrm{~cm}$ bands colored darker or lighter by varying concentrations of clay (Fig. 3; Pl. 2, Fig. 3). In many places the clay occurs as fragments or aggregates a few $\mathrm{mm}$ to a few $\mathrm{cm}$ in size, but in other places it is finely dispersed in the halite. The halite is typically schistose in 1 to $3 \mathrm{~mm}$ crystals, flattened parallel to the banding (Figs. 4, 5). An unusual feature of this core is the frequent occurrence of larger metacrysts or "augen" of halite, 1 to $2 \mathrm{~cm}$ in size, with crushed corners (Fig. 3). The cores of these metacrysts are usually clearer than the surrounding more finely schistose halite, as they are virtually free of clay. The metamorphic aspect of the rock fabric is also evident in a boudinage flow of halite around claystone and anhydrite fragments. Nearly all the banding observed in the core was subhori- zontal; the only steep dips (Section 546-21-2) are in the less competent potash-rich rock.

Anhydrite is much less conspicuous in visual examination of the salt rock than is usual for evaporite sections. Only rarely, as at $546-18-4,31 \mathrm{~cm}, 546-18-4,63 \mathrm{~cm}$, $546-18-5,110 \mathrm{~cm}$, and $546-20-4,55 \mathrm{~cm}$ are there $1 \mathrm{~cm}$ gray bands visibly rich in anhydrite (Appendix). At 546$18-3,65 \mathrm{~cm}, 546-18-5,85 \mathrm{~cm}$, and 546-21-4, $141 \mathrm{~cm}$, the anhydrite shows a definite wavy lamellar texture reminiscent of algal mats replaced by anhydrite. But in general compared with many other evaporite sections (even in some salt domes), this core is unusual in the virtual absence of thick massive anhydrite beds, thin single lamellae of anhydrite, nodular structures, or pseudomorphs after gypsum crystals. A lone example of micronodular texture is illustrated in Plate 2, Figure 1.

The approximate measurements of soluble fraction (see Table 1) indicate that the mean content of insoluble residue-clay and anhydrite combined-is about $5 \%$, but actually $75 \%$ of the section has less insoluble residue.

In thin section the relations of clay, anhydrite, and halite are more evident. Aggregates or larger single crystals of halite are bordered by wispy aggregates of both clay and anhydrite. The clay is opaque and mineralogically unresolvable in the rather thick sections available, with dark brown stain visible on fragment edges. Anhydrite is conspicuous in all salt rock sections as aggregates of rectangular crystals, but in some instances appears as fine $3 \mu \mathrm{m}$ aggregates. Although some anhydrite is dispersed in halite crystals, most of it lies in discontinuous, wispy, curving aggregates (PI. 2, Figs. 2, 3) with the longer $c$ axis of the anhydrite blocks subparallel to the long axis of the aggregate. More often than not, concentrations of anhydrite and clay are contiguous or mixed rather than separately distributed in the halite; apparently they formed anhydrite-clay beds in the original rock (Pl. 2). Dark staining in some anhydrite aggregates may be organic carbon rather than clay. Very fine inclusions are common in anhydrite crystals; whether these inclusions were fluid or solid could not easily be determined.

Fluid inclusions are common in the halite, in some cases as dispersions of negative cubes within the crystals (Pl. 1, Fig. 3), but usually collected along curved polygonal grain boundaries either as sheets of negative cubes or as larger elongate and labyrinthine inclusions (Pl. 1, Fig. 2). This segregation of fluid inclusions to polygonal grain boundaries during recrystallization is typical of salt dome rock (Holser, 1979a, p. 282). One good example of primary inclusions was found in 546-19-2, 33-35 $\mathrm{cm}$. As shown in Plate 1, Figure 4, fluid inclusions are banded along the cube direction with a spacing of about $100 \mu \mathrm{m}$ between bands in the typical chevron pattern (Holser, 1979a, p. 280). A search of the entire core by hand lens, and of all thin sections by microscopy, failed to turn up any other examples of chevron texture, but as only ten sections have so far been made, it is possible that much more of this feature may be present elsewhere in the core.

Only minor amounts of carbonate (probably dolomite) were seen in thin section, mostly as isolated $50 \mu \mathrm{m}$ 


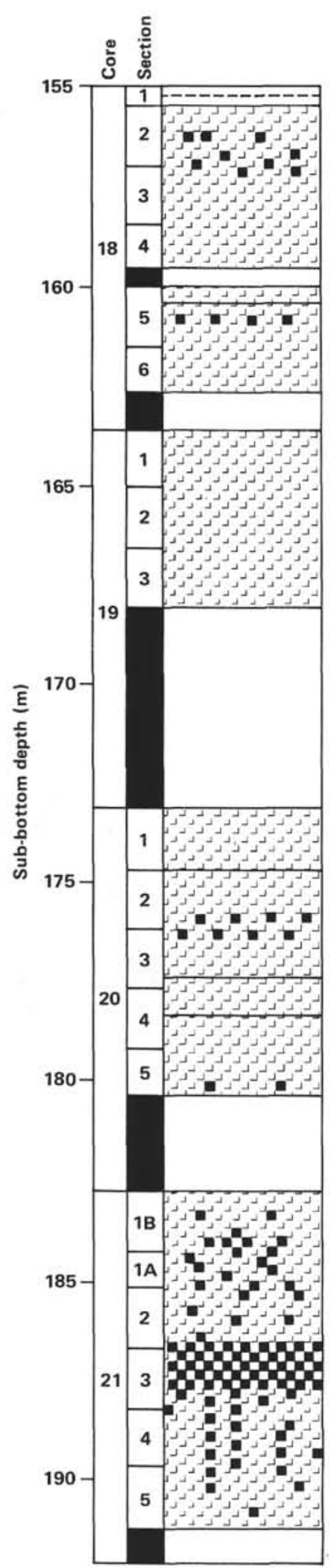

Section 1 is grayish red sandy claystone.

At top of Section 2, contact with salt rock, light gray to pink $3 \mathrm{~mm}$ halite of schistose texture, with 2 to $5 \mathrm{~mm}$ laminae of dark gray to moderate red anhydritic mudstone spaced 1 to $6 \mathrm{~cm}$, dip 0 to $10^{\circ}$. Occasional $1 \mathrm{~mm}$ laminae or disseminations of potash minerals (sylvite, carnallite); surface of core pitted and coated with coppery secondary sylvite, some with selvages of blue halite. Rare dark gray 2 to $5 \mathrm{~mm}$ wispy laminae of anhydrite.

Below $35 \mathrm{~cm}$ in Section 5 and continuing through all of Core 19, red and brown colors begin to dominate over gray and green; increasing 1 to $3 \mathrm{~cm}$ metacrysts of clear halite in schistose halite bands; potash absent. Red and brown colors are in part a mixture of layers or wispy fragments of mudstone, and in part a paler pink disseminated coloration in some halite layers.

Salt rock, olive to yellowish gray, with 1 to $2 \mathrm{~cm}$ alternating darker and lighter bands, more and less rich in clay.

In Sections 2 and 3, reddish and brown colors again begin to dominate.

At base Section 3 there begins $1 \mathrm{~m}$ of laminae and disseminations, and one $6 \mathrm{~cm}$ concentration of potash.

Salt rock, pale to dark reddish brown from admixtures of claystone; halite has $3 \mathrm{~mm}$ schistose texture, enclosing 5 to $1 \mathrm{~mm}$ metacrysts of clearer halite.

Beginning at base of Section 5 , and continuing to bottom of hole, with a maximum in Sections $1 \mathrm{~A}$, 2 , and 3 of Core 21, potash is very common in beds and disseminations; some parts of core are nearly destroyed by solution pitting. The dominant colors in this zone are pinks and browns, but dark green mudstone is common, particularly in association with potash beds. Local plastic deformation, resulting in dips to $60^{\circ}$ and cross-cutting relationships, as at 546-21-2, $105 \mathrm{~cm}$, is confined to potash beds. (Core 21-1B was cut above Core 21-A. See Appendix.)

Figure 2. Summary description of evaporite cores from Site 546. For explanation of symbols see Appendix. 


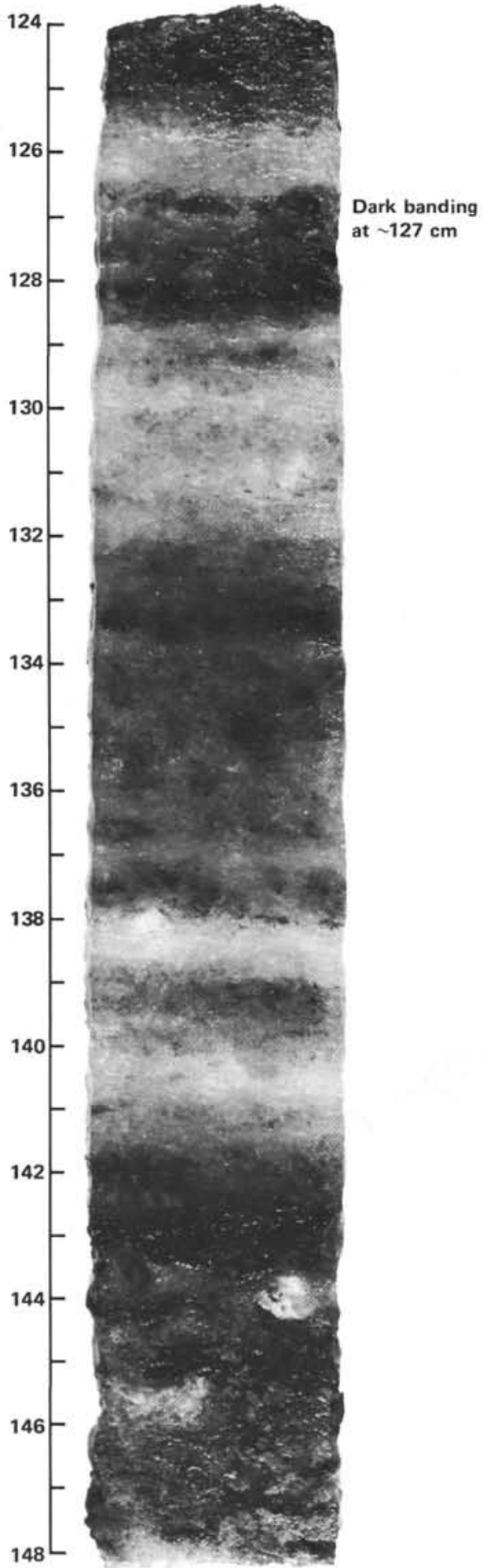

Figure 3. Typical banding in salt rock at $546-20-1,124-148 \mathrm{~cm}$. In this section the rock is typically yellowish gray, with 1 to $2 \mathrm{~cm}$ alternations of nearly clear halite and olive gray clay-rich bands. Some gray bands have a few flecks of brown clay. Halite crystal size increases toward the bottom of the photograph where a few $5 \mathrm{~mm}$ clear halite augen may be seen in a section rather rich in clay.

rhombohedra, but in one case interlayered with anhydrite and clay (Pl. 2, Fig. 3). The presence of magnesite is not excluded. Carbonate minerals appear to be unusually rare in this core.

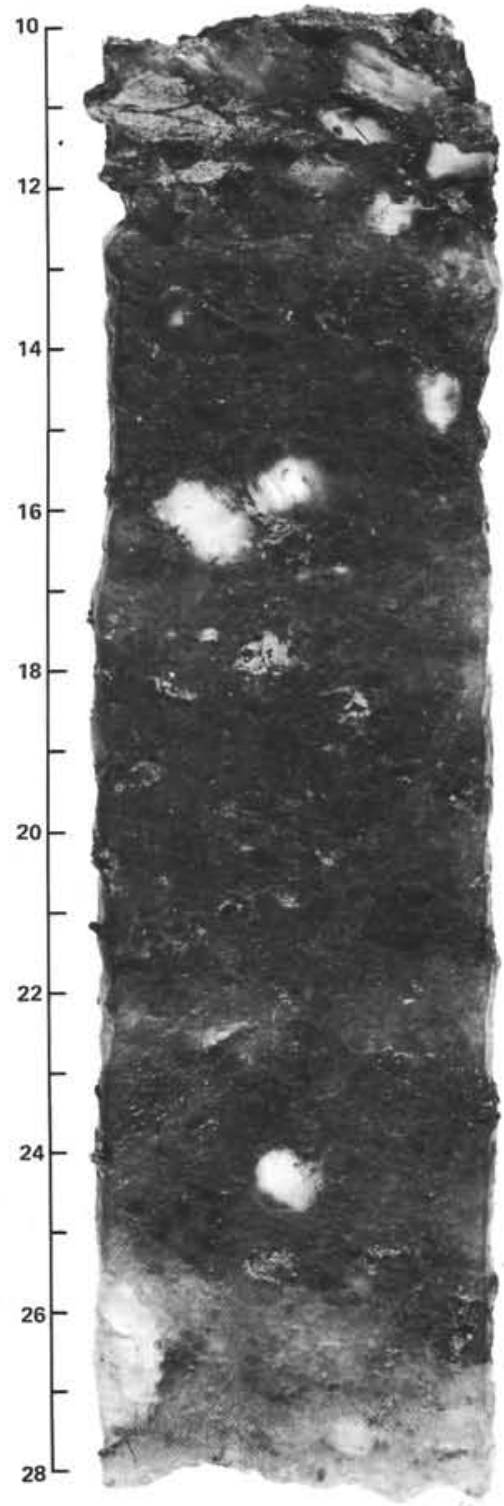

Figure 4. Cataclastic texture and "Augensalz" at 546-21-4, 0-36 cm. The salt rock is greenish gray in the first $20 \mathrm{~cm}(\mathrm{~A})$, and a darker grayish red in the next $8 \mathrm{~cm}$ (B). Prominent 0.3 to $1 \mathrm{~cm}$ augen are moulded by finer $(0.5$ to $1 \mathrm{~mm})$ cataclastic halite and their prominent corners are snubbed by cataclasis. Banding has been somewhat obscured by deformation but may still be clearly seen. Several thin seams of potash mineralization are present but not clear in the photograph.

\section{ELEMENTAL CHEMICAL ANALYSIS OF POTASH MINERALIZATION}

Potash facies minerals were studied by visual examination of the core, thin section microscopy, and elemental analysis. Ground channel and spot samples were leached in distilled water overnight, filtered, and an aliquot of filtrate analyzed for $\mathrm{Mg}$ and $\mathrm{K}$ by standard atomic absorption and emission analysis, respectively. The results are listed in Table 1.

Potash minerals were recognized in the core initially as solution pits on the core surface, evidence that carnallite and sylvite were dissolved faster than halite 


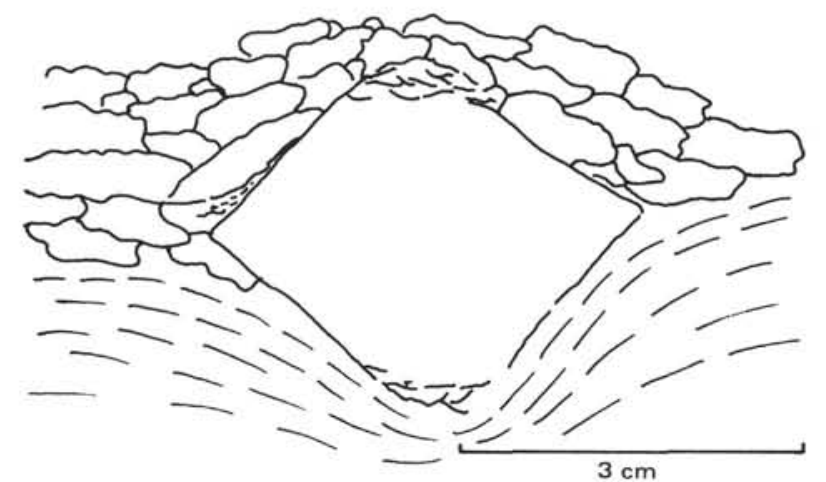

Figure 5. Typical cataclastic texture in salt rock. Clear halite augen are moulded by smaller lenticular crystals of impure halite; the exposed corners of the large augen $(\sim 1.5 \mathrm{~cm})$ are also rounded by fracturing.

(Fig. 6). Many of these solution pits were lined with shiny, copper red, mica-like crystals of sylvite, which occurs when ferroan carnallite on the core surface is attacked by the drilling fluid. Carnallite was recognized on fractured core surfaces as coarse yellowish grains, and in thin section as blocky crystals with a low refractive index and medium retardation (Pl. 3, Figs. 1, 3). Within the core, sylvite showed in thin section as irregularly shaped crystals in halite (Pl. 3, Fig. 2); some of this sylvite also included microscopic hexagonal plates of hematite and is certainly a replacement of primary carnallite. No other definitive relations of sylvite and carnallite were observed in the sections studied.

During visual examination of the core, blue halite (colored intensely by color centers) was observed sporadically in association with potash mineralization. When blue halite occurred it was always with recognizable sylvite or carnallite, but most halite associated with those minerals was colorless. Such an association is usual for blue halite (e.g., Kirchheimer, 1976).

A minor amount of polyhalite was evident in hand lens examination of the core as typical orange-colored wispy aggregates within clear crystals of halite or sylvite. In thin section, it appeared as radiating clusters of $5 \times 100 \mu$ m needles (Pl. 3, Fig. 4). This polyhalite is optically length-fast, with parallel extinction, as previously described from continental Miocene evaporites of Spain (Ortí Cabo and Pueyo Mur, 1980). These optics are compatible with the statement of Palache et al. (1951) that polyhalite is elongate parallel to [001] and the crystallographic description of Braitsch (1961) that measured $\alpha$ $\wedge \mathrm{c}=6^{\circ}$. The optics described by Winchell and Winchell $(1951$, p. 162) when combined with Braitsch's description would give both positive and negative elongation and a large extinction angle; the source of Winchell and Winchell's optics is not stated. The description by Holser (1966) of polyhalite from Baja California with positive elongation and parallel extinction needs rechecking. Whether the variable optics of polyhalite have any genetic significance is unknown at this time.

No other potash facies minerals were noted during visual, thin section, or X-ray diffraction examination of the core. If present, such minerals must be only minor
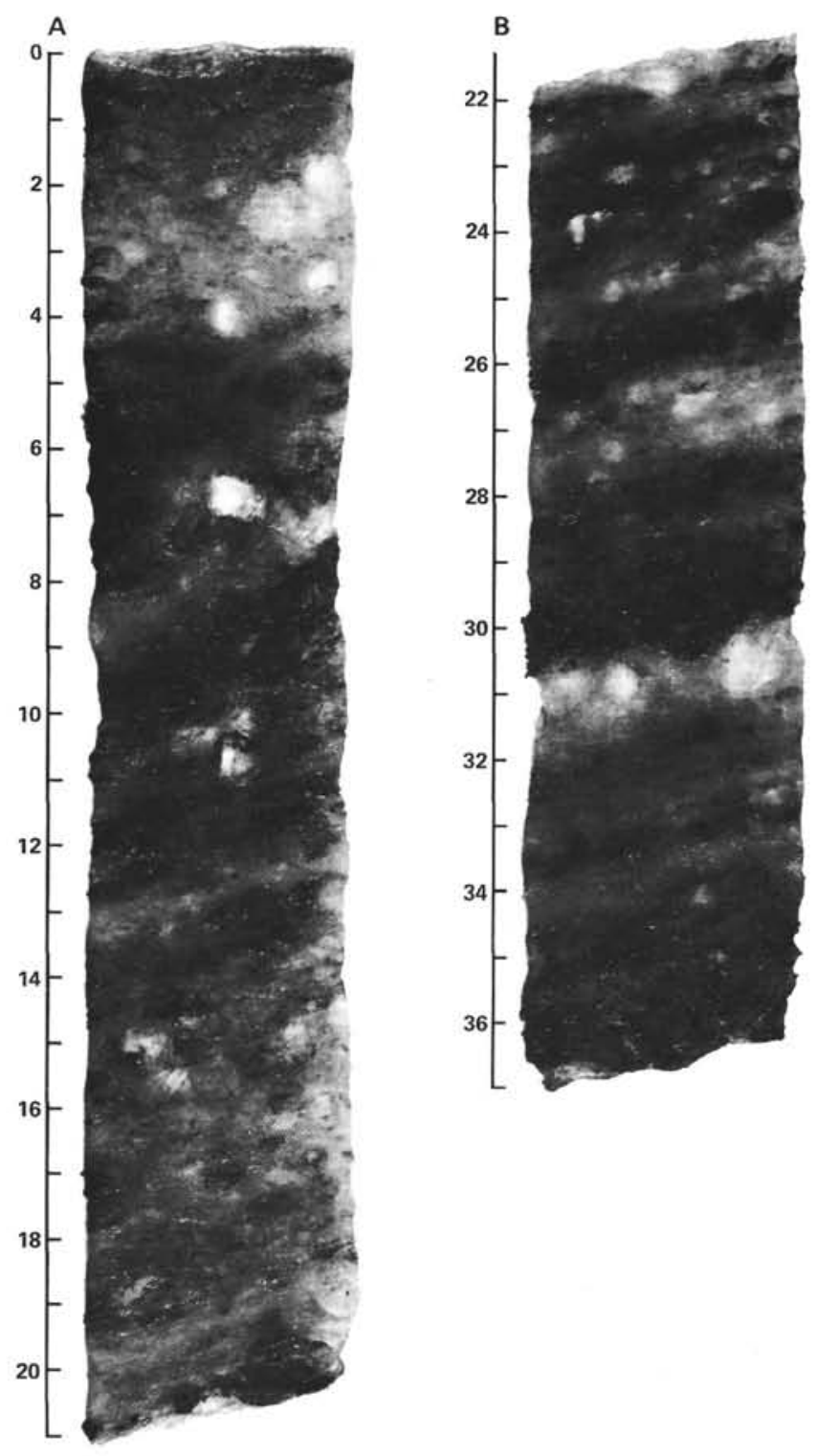

Figure 6. Potash mineralization at $546-20-4,10-28 \mathrm{~cm}$. Rock rich in pale yellow carnallite (with sylvite?) is dark gray in photograph. Much of the section is moderate red, with augen of halite (some stained blue by radiation damage) evident at the base of this section.

components. Consequently, it was possible to estimate the carnallite and sylvite contents of the core by a normative calculation (see Table 1, Fig. 7). The additional assumption made in this calculation was that neither potassium nor magnesium was present in solid solution in halite, although Holser (1979b) has suggested that some tens of ppm K may be in solid solution in halite, 
Table 1. Chemical analyses of salt rocks from Site 546.

\begin{tabular}{|c|c|c|c|c|c|c|c|}
\hline \multirow{2}{*}{$\begin{array}{l}\text { Core-Section } \\
\text { (interval in cm) }\end{array}$} & \multirow{2}{*}{$\begin{array}{l}\text { Solubles } \\
\text { (wt \%) }\end{array}$} & \multirow{2}{*}{$\underset{(\mathrm{ppm} / \mathrm{sol})}{\mathrm{Mg}}$} & \multirow{2}{*}{$\begin{array}{c}\mathrm{K} \\
(\mathrm{ppm} / \mathrm{sol})\end{array}$} & \multirow{2}{*}{$\begin{array}{c}\mathrm{Br} \\
(\mathrm{ppm} / \mathrm{sol})\end{array}$} & \multicolumn{2}{|c|}{$\begin{array}{l}\text { Normative minerals } \\
\text { (wt. \%/sol) }\end{array}$} & \multirow{2}{*}{$\begin{array}{c}\text { Corrected } \\
\mathrm{Br} / \mathrm{NaCl} \\
\text { (ppm) }\end{array}$} \\
\hline & & & & & Carnallite & Sylvite & \\
\hline $18-2,35-59$ & 98.5 & 138 & 3060 & 116 & 0.16 & 0.54 & 110 \\
\hline $18-2,60-94$ & 98.0 & 77 & 6490 & 144 & 0.09 & 1.21 & 129 \\
\hline $18-2,92-94$ & 98.6 & 60 & 1700 & 164 & 0.07 & 0.31 & 159 \\
\hline $18-2,95-119$ & 77.4 & 693 & 24,100 & 180 & 0.79 & 4.38 & 125 \\
\hline $18-2,120-146$ & 96.4 & 145 & 2120 & 142 & 0.17 & 0.36 & 138 \\
\hline $18-3,4-19$ & 94.7 & 394 & 722 & 158 & 0.45 & 0.02 & 154 \\
\hline $18-3,23-62$ & 96.7 & 264 & 1200 & 129 & 0.30 & 0.15 & 125 \\
\hline $18-3,63-99$ & 95.0 & 297 & 6530 & 142 & 0.34 & 1.15 & 126 \\
\hline $18-3,99-126$ & 97.7 & 102 & 4640 & 114 & 0.12 & 0.85 & 105 \\
\hline $18-3,126-150$ & 98.6 & 45 & 6100 & 124 & 0.05 & 1.15 & 112 \\
\hline $18-4,0-31$ & 81.7 & 100 & 521 & 110 & 0.11 & 0.07 & 109 \\
\hline $18-4,64-103$ & 97.5 & 88 & 2120 & 132 & 0.10 & 0.38 & 127 \\
\hline $18-5,4-23$ & 96.0 & 83 & 656 & 78 & 0.09 & 0.10 & 77 \\
\hline $18-5,23-67$ & 98.1 & 122 & 870 & 93 & 0.14 & 0.13 & 91 \\
\hline $18-5,67-109$ & 84.4 & 292 & 930 & 113 & 0.33 & 0.09 & 110 \\
\hline $18-5,109-144$ & 97.4 & 195 & 1150 & 123 & 0.22 & 0.16 & 120 \\
\hline $18-6,0-21$ & 92.5 & 688 & 1770 & 164 & 0.79 & 0.13 & 155 \\
\hline $18-6,21-46$ & 96.8 & 226 & 1300 & 121 & 0.26 & 0.18 & 117 \\
\hline $18-6,46-80$ & 96.1 & 324 & 1690 & 130 & 0.37 & 0.22 & 125 \\
\hline $19-1,0-24$ & 83.1 & 110 & 667 & 116 & 0.12 & 0.09 & 114 \\
\hline $19-1,29-54$ & 97.2 & 158 & 714 & 137 & 0.18 & 0.09 & 134 \\
\hline $19-1,54-98$ & 97.6 & 150 & 755 & 139 & 0.17 & 0.10 & 136 \\
\hline $19-1,19-146$ & 97.0 & 204 & 788 & 140 & 0.23 & 0.09 & 129 \\
\hline $19-2,1-25$ & 95.5 & 470 & 1245 & 142 & 0.54 & 0.09 & 136 \\
\hline $19-2,25-56$ & 96.0 & 569 & 1105 & 158 & 0.65 & 0.04 & 151 \\
\hline $19-2,86-125$ & 96.4 & 606 & 1200 & 151 & 0.69 & 0.04 & 144 \\
\hline $19-2,125-149$ & 94.8 & 706 & 1350 & 140 & 0.81 & 0.04 & 133 \\
\hline $19-3,0-44$ & 96.2 & 632 & 1220 & 141 & 0.72 & 0.04 & 135 \\
\hline $19-3,80-122$ & 97.7 & 352 & 1020 & 138 & 0.40 & 0.09 & 134 \\
\hline $19-3,122-150$ & 80.2 & 475 & 1040 & 138 & 0.54 & 0.05 & 133 \\
\hline $20-1,0-32$ & 92.2 & 785 & 1130 & 189 & 0.90 & $(-0.03)$ & 179 \\
\hline $20-1,62-92$ & 97.0 & 335 & 890 & 159 & 0.38 & 0.05 & 155 \\
\hline $20-1,92-122$ & 96.3 & 519 & 1035 & 187 & 0.59 & 0.04 & 180 \\
\hline $20-1,111-113^{\mathrm{a}}$ & 97.8 & 89 & 559 & 143 & 0.10 & 0.07 & 141 \\
\hline $20-1,113-117^{b}$ & 97.5 & 106 & 620 & 137 & 0.12 & 0.09 & 135 \\
\hline $20-1,117-120^{\mathrm{a}}$ & 98.2 & 96 & 553 & 122 & 0.11 & 0.08 & 121 \\
\hline $20-1,120-122^{b}$ & 94.5 & 450 & 2020 & 159 & 0.51 & 0.25 & 151 \\
\hline $20-1,122-146$ & 95.5 & 286 & 900 & 139 & 0.33 & 0.08 & 135 \\
\hline $20-2,0-41$ & 96.5 & 725 & 1310 & 173 & 0.80 & 0.03 & 165 \\
\hline $20-2,27-28^{\mathrm{a}}$ & 94.0 & 267 & 885 & 120 & 0.30 & 0.08 & 117 \\
\hline $20-2,90-118$ & 96.0 & 631 & 1340 & 177 & 0.72 & 0.06 & 169 \\
\hline $20-2,118-148$ & 95.8 & 505 & 1360 & 164 & 0.57 & 0.10 & 157 \\
\hline $20-3,52-98$ & 96.3 & 614 & 1520 & 186 & 0.70 & 0.10 & 177 \\
\hline $20-3,94-95^{\mathrm{a}}$ & 98.1 & 332 & 1300 & 137 & 0.38 & 0.15 & 133 \\
\hline $20-3,97-98^{b}$ & 86.2 & 1510 & 2980 & 201 & 1.72 & 0.11 & 181 \\
\hline $20-3,98-144$ & 95.2 & 801 & 2140 & 158 & 0.91 & 0.16 & 148 \\
\hline $20-3,105-106^{\mathrm{a}}$ & 97.9 & 332 & 1600 & 142 & 0.38 & 0.20 & 136 \\
\hline $20-3,113-114^{\mathrm{a}}$ & 98.8 & 118 & 1530 & 126 & 0.13 & 0.26 & 114 \\
\hline $20-4,0-29$ & 86.9 & 910 & 13,000 & 165 & 1.04 & 2.20 & 131 \\
\hline $20-4,29-54$ & 94.3 & 565 & 1930 & 142 & 0.64 & 0.19 & 135 \\
\hline $20-4,54-104$ & 95.0 & 510 & 1660 & 152 & 0.58 & 0.16 & 145 \\
\hline $20-4,104-149$ & 94.7 & 760 & 1690 & 153 & 0.87 & 0.47 & 140 \\
\hline $20-5,0-45$ & 95.3 & 778 & 1620 & 161 & 0.89 & 0.07 & 152 \\
\hline $20-5,45-70$ & 82.9 & 848 & 1750 & 155 & 0.97 & 0.07 & 146 \\
\hline $20-5,70-112$ & 95.5 & 1000 & 4400 & 160 & 1.14 & 0.53 & 143 \\
\hline $21-1 B, 0-2$ & 97.8 & 707 & 1520 & 149 & 0.81 & 0.07 & 141 \\
\hline $21-1 B, 28-30$ & 98.2 & 299 & 3700 & 150 & 0.34 & 0.61 & 139 \\
\hline $21-1 B, 55-56$ & 97.4 & 250 & 2120 & 147 & 0.29 & 0.33 & 140 \\
\hline 21-1B, 90-91 & 94.8 & 1257 & 2310 & 149 & 1.46 & 0.06 & 136 \\
\hline $21-1 B, 114-116$ & 98.0 & 219 & 1510 & 123 & 0.25 & 0.22 & 119 \\
\hline $21-1 \mathrm{~A}, 5-7$ & 98.2 & 130 & 1500 & 133 & 0.15 & 0.25 & 129 \\
\hline $21-1 \mathrm{~A}, 30-32$ & 98.3 & 260 & 2110 & 134 & 0.30 & 0.32 & 128 \\
\hline $21-1 A, 60-62$ & 97.6 & 143 & 1105 & 123 & 0.16 & 0.17 & 120 \\
\hline $21-2,0-2$ & 98.4 & 327 & 1710 & 133 & 0.37 & 0.23 & 127 \\
\hline $21-2,58-59$ & 98.5 & 472 & 3510 & 128 & 0.54 & 0.52 & 119 \\
\hline $21-2,84-85$ & 99.2 & 83 & 1910 & 149 & 0.09 & 0.34 & 144 \\
\hline $21-2,138-139$ & 89.1 & 2845 & 16,200 & 191 & 3.25 & 2.22 & 137 \\
\hline $21-3,0-1$ & 97.8 & 367 & 3990 & 140 & 0.42 & 0.65 & 129 \\
\hline $21-3,44-45$ & 97.8 & 343 & 2440 & 131 & 0.39 & 0.36 & 124 \\
\hline $21-3,84-85$ & 99.2 & 653 & 5110 & 138 & 0.75 & 0.77 & 124 \\
\hline $21-4,0-36$ & 97.2 & 173 & 13,050 & 144 & 0.20 & 2.44 & 117 \\
\hline $21-4,36-75$ & 96.1 & 355 & 2210 & 161 & 0.41 & 0.42 & 151 \\
\hline $21-4,75-98$ & 96.5 & 323 & 1870 & 152 & 0.37 & 0.26 & 145 \\
\hline $21-4,98-130$ & 77.8 & 360 & 1930 & 145 & 0.41 & 0.26 & 138 \\
\hline
\end{tabular}


Table 1. (Continued).

\begin{tabular}{lccccccc}
\hline $\begin{array}{c}\text { Core-Section } \\
\text { (interval in cm) }\end{array}$ & $\begin{array}{c}\text { Solubles } \\
(\mathrm{wt} \%)\end{array}$ & $\begin{array}{c}\mathrm{Mg} \\
(\mathrm{ppm} / \mathrm{sol})\end{array}$ & $\begin{array}{c}\mathrm{K} \\
(\mathrm{ppm} / \mathrm{sol})\end{array}$ & $\begin{array}{c}\mathrm{Br} \\
(\mathrm{ppm} / \mathrm{sol})\end{array}$ & $\begin{array}{c}\text { Normative minerals } \\
\text { (wt.\%/sol) }\end{array}$ & $\begin{array}{c}\text { Corrected } \\
\mathrm{Br} / \mathrm{NaCl}\end{array}$ \\
\hline $21-4,130-149$ & 89.1 & 1070 & 7480 & 164 & 1.22 & 1.10 & 140 \\
$21-5,0-34$ & 96.8 & 411 & 2840 & 147 & 0.47 & 0.42 & 139 \\
$21-5,34-64$ & 97.6 & 197 & 1400 & 148 & 0.22 & 0.21 & 143 \\
$21-5,64-83$ & 96.6 & 217 & 1650 & 126 & 0.25 & 0.25 & 121 \\
Mean & $94.9 \pm 0.7$ & & & & & & \\
\hline
\end{tabular}

${ }^{a}$ Relatively clear layer.

b Relatively dark, dirty layer.

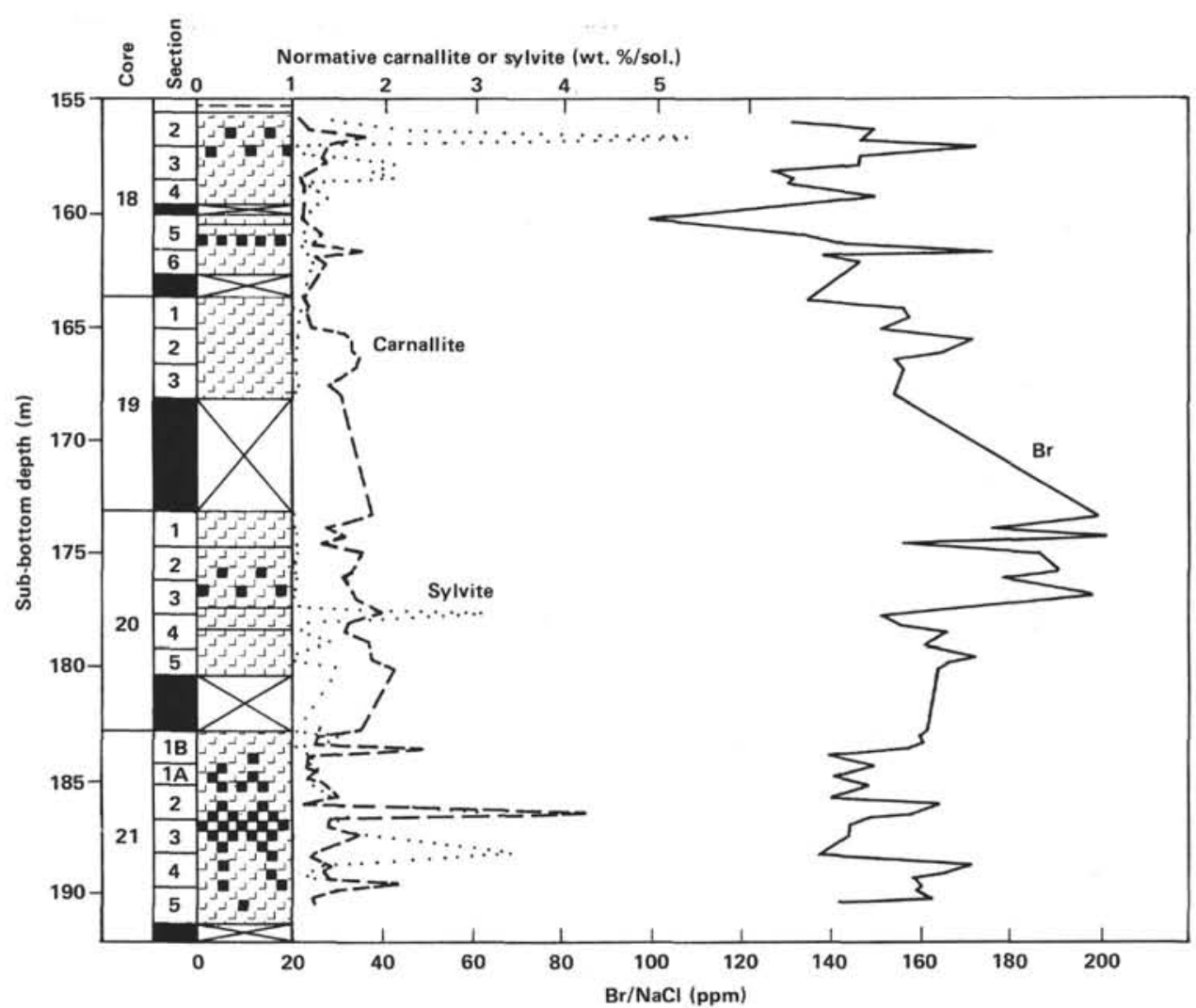

Figure 7. Chemical analyses of salt rock from Site 546. The results of whole rock analysis, mostly of 20 to $50 \mathrm{~cm}$ channel samples, are expressed here as \% total solubles, normative carnallite, normative sylvite, and calculated ppm Br/ $\mathrm{NaCl}$. (See Appendix, Parts 14 and 15, for explanation of section numbering in Core 21.)

amounting to a negligible correction to the hundreds and thousands of ppm $\mathrm{K}$ recorded in Table 1 . Some $\mathrm{K}$ and $\mathrm{Mg}$ may also be present in fluid inclusions. Calculation of analyzed $\mathrm{Mg}$ as bischofite, $\mathrm{MgCl}_{2} \cdot 6 \mathrm{H}_{2} \mathrm{O}$, as was done by Kuehn and Hsü (1978), is completely unjustified and erroneously implies the possible presence of that rare mineral. One verification of the normative calculation is that the $\mathrm{K}$ remaining for sylvite after combining with all $\mathrm{Mg}$ for carnallite is slightly negative in only a single case. The calculated normative contents of carnallite, most of which can be presumed to be primary, range from 0.1 to over $3 \mathrm{wt} . \%$ carnallite, but nearly all values are a few tenths of a percent. With very few exceptions, all of the core below the first two sections
(546-18-2, and 546-18-3) show carnallite greater than sylvite. This difference can possibly be explained by a greater dissolution of carnallite (and conversion to sylvite) by the drilling fluid after it first encountered the salt rock and had not yet become saturated with $\mathrm{NaCl}$ (or $\mathrm{MgCl}_{2}$ ). In any case, most of the potash mineralization appears to be carnallite. The main concentrations $(>0.5 \%)$ of potash mineralization are in Sections 546$18-2$ to $546-18-3,546-20-2$ through $546-21-1 \mathrm{~B}$, and from the base of 546-21-2 through 546-21-4.

\section{BROMIDE GEOCHEMISTRY}

Bromide analyses of salt rocks are a powerful tool for interpreting their history as well as providing informa- 
tion on the stage of evaporation, conditions of crystallization, and marine versus nonmarine origin of the brines from which the rocks formed. The geochemical principles and experience of bromide geochemistry have been reviewed in several publications (e.g., Holser, 1979b); however, in brief, during crystallization of chloride minerals from seawater, bromide fractionates into the mineral and provides a measure of bromide concentration in the brine which gradually builds up as the remaining rejected bromide accumulates in later brines. The repeated desiccations that are expected in sabkha or playa evaporites tend to give erratically high values, whereas freshening of an evaporite basin brine by increased input and reflux of seawater will cause the profile of bromide values to decline. Second, cycle brines formed by the re-solution (by new sea water or fresh water) of older marine salt rocks are much poorer in bromide than normal marine evaporites.

In order to get an overall picture of bromide in the core, most analyses were performed on channel samples representing 20 to $50 \mathrm{~cm}$ of core. Where this was not possible, the usual spot samples were used. An aliquot of the samples prepared for chemical analysis, as described above, was taken for bromide analysis. Inasmuch as these samples were dissolved, filtered, recrystallized, and thoroughly mixed before weighing, the results are stated as $\mathrm{ppm} \mathrm{Br} /$ total soluble salts by weight. A weighed sample of the recrystallized salt was dissolved in distilled water and analyzed colorimetrically by the standard chloramine-T method (Goldman and Byles, 1959). A precision of $\pm 1 \%$ of the analyzed value was established by repeated analysis of two laboratory standards (AR $\mathrm{NaCl}$ at $54 \mathrm{ppm}$ and $\mathrm{AR} \mathrm{KCl}$ at $114 \mathrm{ppm}$ ).

The results of bromide analysis are listed in Table 1. The values range from 80 to $200 \mathrm{ppm} \mathrm{Br} /$ solubles. It would be desirable to compare samples with each other in terms of the bromide content of halite alone. The analyses of bromide in total solubles are distorted by two other sites of bromide concentration, in fluid inclusions and in the potash minerals carnallite and sylvite. Thin section study, as described above, indicates that fluid inclusions are rather uncommon in these salts and are estimated to be less than $0.1 \%$. So despite an equilibrium concentration in fluid inclusion brines of about 10 times that of the associated halite, such brines will increase the total bromide by less than only $1 \%$. In the absence of quantitative analyses for brine or water content, this source of error is hereafter disregarded. On the other hand, increase of bromide above that for pure halite owing to the presence of carnallite and/or sylvite is significant where the levels of these minerals reach $1 \%$ or more in some parts of the core. In the absence of analyses of mineral separates that have not yet been made, it is still possible and indeed customary (e.g., Es-Said, 1974) to make an approximate correction to the bromide level by assuming that the carnallite and sylvite are both primary and are at equilibrium with the halite (i.e., all three minerals are crystallized each in equilibrium with the same brine). The appropriate distribution coefficients are such that sylvite has about 10 times as much bro- mide as coexisting halite and carnallite about 7 times as much (Kühn, 1968). One can therefore correct to

$$
\begin{aligned}
\text { ppm } \mathrm{Br} / \mathrm{NaCl} & =(\text { ppm } \mathrm{Br} / \text { sol }) /[1+(0.06 \times \% \text { carnallite }) \\
& +(0.09 \times \% \text { sylvite })]
\end{aligned}
$$

If the sylvite did replace the carnallite, as indeed may be the case, its factor would have been about 7 instead of 10 (Kühn, 1968); but sylvite is only important in a few samples at the top of the core. Another way of considering the effect of carnallite and sylvite on the bromide level is to compare those samples high in carnallite (or alternatively sylvite) with nearby samples that contain purer halite. Such comparisons in general show the expected rise of total bromide with carnallite content, but no very significant correlation of bromide with sylvite content.

Thus, fluid inclusions would have increased the correction, whereas secondary sylvite or solid-solution $\mathrm{Na}(\mathrm{K}) \mathrm{Cl}$ would have decreased the correction; therefore, the calculated value (Table 1, column 8) may be considered to be a best estimate. The high values of $\mathrm{Br}$ are generally reduced, to a maximum of $180 \mathrm{ppm} \mathrm{Br} / \mathrm{NaCl}$, whereas the low values are little affected. The moderate amount of variation in the original bromide profile is also smoothed in the corrected profile. Most of the profile, as displayed in Figure 7, is in the range 120-150 $\mathrm{ppm} \mathrm{Br} / \mathrm{NaCl}$. With only a handful of exceptions, those samples whose significant content of potash minerals (e.g., $>0.5 \%$ ) places them clearly in the potash facies have $\mathrm{Br} / \mathrm{NaCl}$ greater than $135 \mathrm{ppm}$. The profile is generally moderately high $(135-150 \mathrm{ppm})$ in its lower part, has a minimum of about $80 \mathrm{ppm}$ in Section 546-18-5, and rises again toward the top of the core. That general trend presumably embraces two cycles of high evapgration, both within the lower part of the potash facies, separated by a brief excursion back into the halite facies. There was some tendency for high values of $\mathrm{Br} /$ $\mathrm{NaCl}$ to be associated with the darker bands of salt rock rich in greenish colored clay; compare 546-20-3, 97-98 $\mathrm{cm}$ with the immediately overlying $546-20-3,94-95 \mathrm{~cm}$ and 546-20-1, 120-122 cm with the overlying 546-20-1, $117-120 \mathrm{~cm}$ (Table 1). But where the dark-light banding of the salt rock depended on only a minor dispersion of clay, this contrast was lost. An alternative interpretation is that the "cycles" are tectonically emplaced segments.

Within those general trends, the variations are similar to those found in the majority of evaporite sections, being neither as regular as those found in a few evaporites such as Zechstein 2, nor as wildly irregular as those found in other evaporites (marine and nonmarine) that have presumably been repeatedly desiccated (Holser, $1979 b)$. In a very general sense, the bromide profile indicates that the brine depositing these salts may have been rather shallow but not desiccated.

The maximum values of $180 \mathrm{ppm} \mathrm{Br} / \mathrm{NaCl}$ are about what one would expect from the evaporation of seawater (of present $\mathrm{Br}$ content) to the beginning of the potash facies (Holser, 1979b). The presence of significant potash minerals at a $\mathrm{Br} / \mathrm{NaCl}$ level of $135 \mathrm{ppm}$ could be explained by a small contribution from a second cycle 
of crystallization of originally marine halides. This could have been either an older marine evaporite terrane that contributed $\mathrm{Br}$-poor halides to the brines of the basin, or, more likely, a local recycling of salts from one part of the basin to another shortly after deposition ("descendent" salts, see Holser, 1979b, p. 319). But the bromide data indicate that any such contribution was minor and that the bulk of the salts were of first-cycle marine origin.

\section{STABLE ISOTOPE GEOCHEMISTRY}

Sulfur isotope ratios in the sulfate of marine evaporites sample the sulfate coming in from surface ocean waters without substantial fractionation. The marine value at any one time represents a dynamic balance of erosional inputs and depositional outputs of isotopically light sulfide and heavy sulfate, the difference generated by the worldwide activity of sulfur-reducing bacteria. Variations in this balance through geological time are recorded in the "sulfur isotope age curve" (Fig. 3) that has been constructed from several thousand analyses of marine evaporite sulfates with emphasis on interbasin correlations. These and other aspects of sulfur isotope geochemistry in the exogenic cycle have been reviewed by Nielsen (1977) and Claypool et al. (1980) among others. The cycle of oxygen in sulfate is similar but more variable in interbasin correlations, is less well documented, and is less well understood (Holser et al., 1979).

Sulfur (and probably oxygen) isotope ratios are constant among evaporite facies, solution and redeposition, and most other geological processes until biological reduction intervenes (Holser and Kaplan, 1966). Evidence from the interbasin correlations indicates that within most evaporite basins any sulfur reduction is overwhelmed by the inflow of new marine sulfate. Consequently, if an evaporite is known to be marine (e.g., from paleogeography, paleontology, or bromide data on the salt facies), comparison of its sulfur isotope ratio with the sulfur isotope age curve will indicate one or more ages with which the isotope data are compatible. Conversely, if the age of the evaporite is known from other geological correlations, comparison of its sulfur isotope ratio with the sulfur isotope age curve constructed from other marine evaporites will suggest the extent to which its sulfate comes from marine origins of that age or comes from other sulfur. "Other sulfur" could be marine sulfate from an earlier part of the curve or sulfate from the oxidation and erosion of sulfide minerals (of either igneous or sedimentary origin).

Spot samples were taken for stable isotope analysis at six points on the core chosen to contain appreciable concentrations of anhydrite (Appendix). As a first step for isotope analysis, whole rock samples were dissolved in cold $\mathrm{HCl}$, passed through a cation exchange column, adjusted to $\mathrm{pH}=2$, then precipitated as $\mathrm{BaSO}_{4}$ (Sakai, 1977). For sulfur isotope analysis, an aliquot of the $\mathrm{BaSO}_{4}$ was thermally decomposed to $\mathrm{SO}_{2}$ (Holt and Engelkemeir, 1970; Bailey and Smith, 1972) and then analyzed on a Micromass 602 mass spectrometer. The results are recorded as $\delta^{34} \mathrm{~S}$ relative to the CDT standard, with a reproducibility of $\pm 0.15 \%$. For oxygen isotope analysis an aliquot of $\mathrm{BaSO}_{4}$ was heated in an electrical resistance furnace with graphite at $1110^{\circ} \mathrm{C}$ to form $\mathrm{CO}_{2}$ (Sakai and Krouse, 1971). Any CO in the product was converted to $\mathrm{CO}_{2}$ in an electrical discharge cell. The $\mathrm{CO}_{2}$ was analyzed in a mass spectrometer. Results are recorded as $\delta^{18} \mathrm{O}$ relative to the SMOW standard, assuming a fractionation $\mathrm{H}_{2} \mathrm{O}-\mathrm{CO}_{2}$ of 1.0407 . Four analyses of the single sample gave a reproducibility of $\pm 0.2 \%$.

Results of the stable isotope analyses are given in Table 2. The sulfur isotope analyses of the salt rock form a compact group at $\delta^{34} \mathrm{~S}=+10.1 \pm 0.9$. As shown in Figure 8, this value is characteristic of marine evaporites of Permian or very earliest Triassic age. In particu-

Table 2. Isotope ratios in evaporite sulfate from Site 546.

\begin{tabular}{lrr}
\hline $\begin{array}{c}\text { Core-Section } \\
\text { (interval in cm) }\end{array}$ & $\delta^{34} \mathrm{~S}\left(\%_{0} \mathrm{CDT}\right)$ & $\delta^{18} \mathrm{O}\left(\%_{0}\right.$ SMOW) \\
\hline $18-1,86-88^{\mathrm{a}}$ & +11.8 & \\
$18-2,34-39$ & 9.6 & \\
$18-2,62-64$ & 9.7 & \\
$18-2,92-94$ & 9.2 & $+11.3 \pm 0.2$ \\
$19-2,61-65$ & 10.2 & \\
$21-1 \mathrm{~B}, 0-2$ & 10.1 & \\
\hline
\end{tabular}

a Gypsiferous claystone "cap rock"; all others are salt rock.

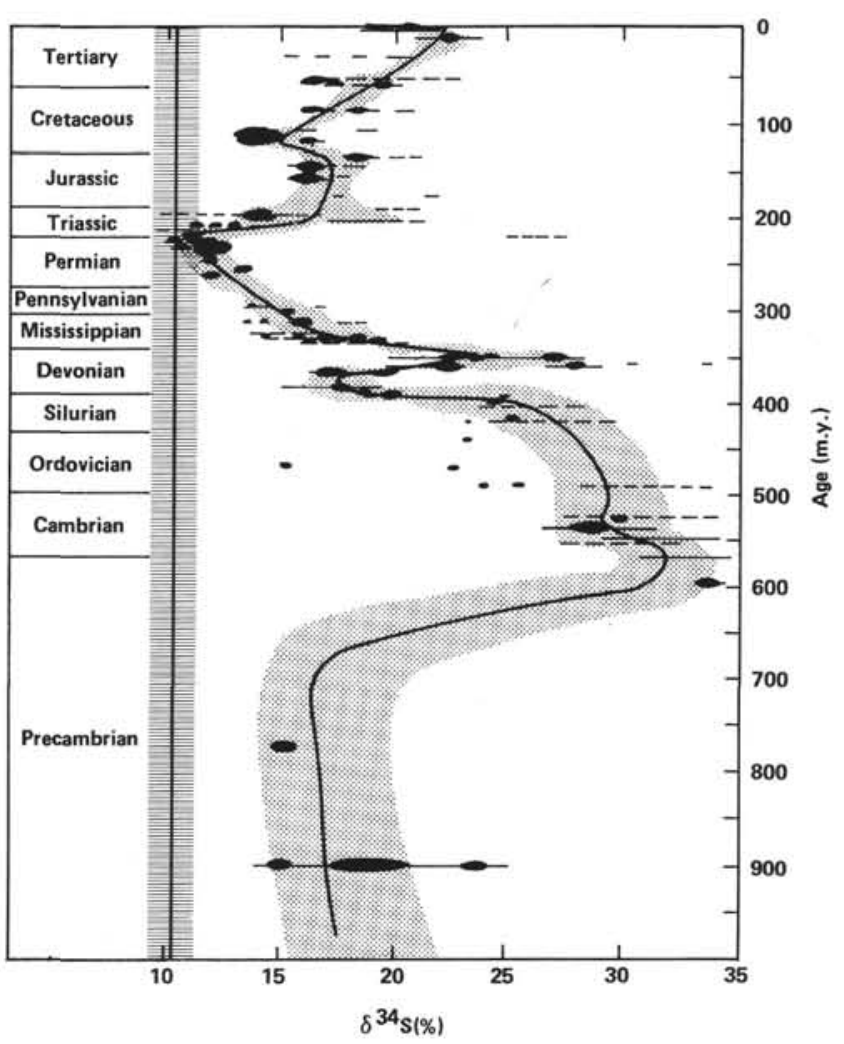

Figure 8. Sulfur isotope age curve for marine sulfate (Claypool et al., 1980). The heavy line is the best estimate for $\delta^{34} \mathrm{~S}$ in sulfate mineral equilibrium with the world ocean surface sulfate of that time; the shaded area is an estimate of the uncertainty of that line. The band on the left is the mean and standard deviation of $\delta^{34} \mathrm{~S}$ in sulfate from Site 546 . 
lar, nearly 400 analyses of marine evaporites from worldwide localities of late Permian age have a mean of $\delta^{34} \mathrm{~S}$ $=+10.2 \%$, whereas those from the early Permian and early in the Scythian stage of the Triassic are only slightly higher. At no other time in the entire Phanerozoic has $\delta^{34} \mathrm{~S}$ previously been found to be so low. From the Carnian stage of the Triassic through the Barremian stage of the Cretaceous, mean values of published $\delta^{34} \mathrm{~S}$ varied between +15 and $+17 \%$, and were mostly in the higher part of that range (Fig. 8; Saltzman et al., 1982).

A question arises as to whether isotopic fractionation during crystallization of the last part of the sulfate in the potash facies may have depressed $\delta^{34} \mathrm{~S}$ below the value of $+16 \%$ expected from late Triassic seawater. Such an origin of the low values is very unlikely on two counts. First, although maximum fractionations of nearly $-4 \% 0$ can be calculated theoretically (Holser and Kaplan, 1966) and smaller differences in this direction have been detected (Nielsen and Ricke, 1964; Holser and Kaplan, 1966), a re-evaluation of the large number of analyses now available of both anhydrite facies (100 samples) and potash facies ( 25 samples) from the Zechstein and Delaware basins shows that the means (anhydrite minus potash) differ by only about $1 \%$. Considering the variance in each facies, this difference is not significant even at a level of $30 \%$ probability (see Claypool et al., 1980, p. 206). Second, the small variations of $\delta^{34} \mathrm{~S}$ displayed in this core are not correlated with $\mathrm{Br} / \mathrm{NaCl}$, and the latter is an independent measure of the fraction of chloride precipitated, and with appropriate scaling, also a measure of the fraction of sulfate precipitated.

The determination of $\delta^{18} \mathrm{O}_{\mathrm{SO}_{4}}=+11.3 \pm 0.2$ (Table 2) is in agreement with the sulfur data, although, as mentioned above, the background of oxygen data is not as definitive. Claypool et al. (1980) summarized all the data available at that time for $\delta^{18} \mathrm{O}$ of marine sulfate evaporite aggregated by geological period. Their mean of $\delta^{18} \mathrm{O}=+11.0 \pm 0.3$ for Permian evaporites was significantly different at the $95 \%$ confidence level from both the Triassic $\left(\delta^{18} \mathrm{O}=+12.2 \pm 0.7\right)$ and the Jurassic $\left(\delta^{18} \mathrm{O}\right.$ $=+13.4 \pm 0.3$ ); Triassic and Jurassic did not differ significantly from each other (Claypool et al., 1980, table 1).

\section{RADIOMETRIC DATING}

Radiometric dating has the potential of providing important information on times of deposition, postdepositional diagenesis, burial metamorphism, or diapiric deformation. Potassium minerals are the vehicle either as nonmineralic or as whole rock samples through the $\mathrm{K} / \mathrm{Ar}$ method for structural $\mathrm{K}$ or the $\mathrm{Rb} / \mathrm{Sr}$ method for $\mathrm{Rb}$ in solid-solution substitution for K. A concordance of dates by $\mathrm{K} / \mathrm{Ar}$ and $\mathrm{Rb} / \mathrm{Sr}$ on the same sample is preferred to confirm dates obtained. Radiometric dating of evaporite rocks was reviewed by Lippolt (1977). The $\mathrm{Rb} / \mathrm{Sr}$ method has been the most successful in dating postdepositional diagenesis of undisturbed evaporites (Register and Brookins, 1980), doming (Lippolt and Raczek, 1979), or other deformation (Oesterle and Lippolt, 1975). The K/Ar method has also been successful when applied to the potassium sulfate minerals langbeinite and polyhalite for dates of deposition (Pilot and Blank, 1967; Schilling, 1973), diagenesis (Brookins, 1980; Brookins et al., 1980), and deformation (Oesterle and Lippolt, 1975). Numerous attempts to date the chloride minerals sylvite and carnallite by the K/Ar method have been unsuccessful owing to continuous diffusive loss of radiogenic Ar.

We report here initial trials of radiometric dating of evaporites from Site 546. Nine whole rock samples chosen for evident concentrations of carnallite and/or sylvite were analyzed by the $\mathrm{Rb} / \mathrm{Sr}$ method. Analysis was by isotope dilution using ${ }^{84} \mathrm{Sr}$ - and ${ }^{87} \mathrm{Sr}$-enriched spikes on the same sample. $\mathrm{Rb}$ and $\mathrm{Sr}$ were separated by ion exchange chromatography and analyzed on a Nier-design Nuclide 1290 mass spectrometer.

Unfortunately this trial was not successful. A wide scatter in both ${ }^{87} \mathrm{Sr} /{ }^{86} \mathrm{Sr}$ and ${ }^{87} \mathrm{Rb} /{ }^{86} \mathrm{Sr}$, much beyond analytical uncertainty, suggests either open system resetting in the evaporite or some type of contamination. Further analyses are now in progress on mineral separates, including polyhalite.

\section{DISCUSSION}

\section{Perspective on the Core Material}

At the outset we would like to emphasize that the interest in and importance of this unique core is somewhat offset by its very limited coverage. It is only one $35 \mathrm{~m}$ sample of a single salt dome that is at least $4 \mathrm{~km}$ wide and probably equally deep. The rock squeezed into this dome probably represented several kilometers of original stratigraphic section of evaporite rocks. Even with the horizontal aspect of the beds in core, we are sampling only a fraction of a percent of the section. Although we may speculate that the cored rocks are somewhere high in the stratigraphic section, experience in salt domes that have been extensively explored by mining and drilling (e.g., Zechstein domes north of Hannover, Germany, see Richter-Bernberg, 1972) demonstrates an exceedingly complex folded and faulted structure.

The dome is one of many in a belt of diapiric structures that extends for $1000 \mathrm{~km}$ along the Moroccan coast; no others in this belt have so far been even drilled, much less sampled. The even more extensive continuations of this evaporite province along both sides of the present Atlantic and even those accessible on land across North Africa are still virtually unstudied in terms of their geochemistry and petrography.

Site 546 is strategically located very close to the eastern edge of the offshore diapiric zone which may also be inferred as close to the eastern edge of the thickest section of original salt because thickness is one requirement for diapirism. Presumably, therefore, the basal salt in the stratigraphic section of this dome came from the oldest rift valley fillings. Basal salts to the westward, as well as overlying salts at Site 546 , would have been deposited during later widening of the rift valley. The evaporites from onshore Morocco, with the probable exception of those in the Essaouira Basin, were most likely deposited on a cratonic shelf, but at an undetermined relation in time and structure to the rift band. 


\section{Evaporite Mineralogy and Facies}

The presence of carnallite, sylvite, and polyhalite signal the high evaporation of the potash facies. The higher ranges of $\mathrm{Br} / \mathrm{NaCl}$ conform to previous experience with salt rocks in the potash facies and the lower values around Section 546-18-5 indicate a freshening back into the upper part of the halite facies. The anhydrite found in thin section is normal for the halite facies, but nowhere in this particular core did thick anhydrite beds free of halite indicate that the facies had regressed as far as the $\mathrm{CaSO}_{4}$ facies nor did the $\mathrm{Br} / \mathrm{NaCl}$ levels suggest that this facies was approached.

The potash facies is rather rare in evaporite sections: in Paleozoic evaporite basins Zharkov's census (1981, p. 157) indicates only $1 \%$ of their volume is in the potash facies. In the North Atlantic basins, the most important potash occurrence previously known is at Khemisset in the onshore Rharb Basin of Morocco where moderate concentrations of carnallite are found in the "Sel Inferieur" formation underlying a section of mafic igneous rocks that divides the evaporite section (Amadé, 1965). Lesser amounts were subsequently found in an analogous geological situation in the onshore Berrechid Basin near Mohammedia (unpublished reports in the files of the Bureau de Recherche et Participation Miniere, Rabat). In the salt intrusion at Tissa in the pre-Rif of Morocco, bromide analyses indicate the beginning of the potash facies (Kulke, 1978, p. 130). Prospecting for potash in the dome at Caldas da Rainha, Portugal, uncovered traces of $\mathrm{K}_{2} \mathrm{O}$ (Zbyszewski, 1959). In the western Atlantic potash has not been detected in well logs or well cuttings, and the one published bromide profile of salt rock in the Osprey Evaporite (Jansa et al., 1980) does not suggest its presence there. In general, therefore, indications of potash facies rocks are no more prevalent in the North Atlantic evaporites than in other basins.

\section{Sedimentary Facies and Diagenesis}

The nonevaporitic contribution to the sediments in the core has not yet been studied in detail. The total insoluble residues average about $5 \%$ in the core (Table 1 ). Most of this is now fragmented into boudins, but looks as if it had originally deposited as 1 to $3 \mathrm{~cm}$ layers interbedded with the halite; single beds of clastics up to $20 \mathrm{~cm}$ thick are visible (Appendix). Most of this is siltstone or mudstone. Quartz is seen in thin section and presumably is dominant in these sediments; no authigenic quartz of the fibrous length-fast or bipyramidal types has so far been recognized. The clay-mineral components, which include well-ordered, mixed layer illitesmectite, illite, and kaolinite, are described in further detail by Chamley (this volume). For comparison, clastics associated with evaporites onshore Morocco are quartz-muscovite-chlorite claystones or quartz-rich sandstones (Kulke, 1978, p. 104) and, in particular, the salt intrusion at Tissa contains quartz, kaolinite, and illite (Kulke, 1978, p. 74). Descriptions of other correlative continental red beds for onshore Morocco are found in Tixeront (1973) and Lorenz (1976) and for offshore
Canada by Jansa et al. (1980). Red, brown, and yellow colorations are common in the core, both as fragments of claystone and dispersions of clay in the halite (Appendix) - in the redder material, some hematite crystals are seen in thin section. Various hues of greenish black to gray appear in about an equal amount of the core (Appendix). Presumably such differences represent oxidizing and reducing conditions, respectively, but the geological conditions of their origin are controversial. Although it seems to be established that red coloration in alluvial sediments is diagenetic (Walker, 1967; Glennie, 1970), it is not clear whether this applies to marine sediments and, in particular, to marine evaporites. A variety of sources of red coloration in the Zechstein evaporites, both primary and diagenetic, have been documented petrographically (Richter, 1962; 1964) and the geochemistry involved has been summarized by Kühn (1968, p. 471). Gerhard Richter-Bernburg (pers. comm.) asserts that only the shallow nearshore facies of the Zechstein Basin evaporites (in cycles Z1 and Z2) have red and brown colors whereas all the deeper facies are gray to greenish gray, but this statement does not seem to have been expressly documented. If this generalization is true, does it mean that at least some of the red coloration in the nearshore evaporites derives from diagenetic alteration of fluviatile sediments before they were eroded into the evaporite basin?

Hematite-colored sylvite derivative from ferroan carnallite implies a more complex history. Iron in seawater is four orders of magnitude too small to account for the $0.5 \%$ commonly found in carnallite (Kühn, 1968). Consequently it must have been introduced into the basin either as the oxidized mineral (goethite or hematite) mentioned above or as detrital ferrous silicates. It, then, must have been mobilized as $\mathrm{Fe}^{2+}$ in solution for incorporation into carnallite solid solutions, implying general reducing conditions in the brine from which the carnallite crystallized. Whereas that condition is not unreasonable in view of the density stratification in evaporite brines, a further oxidation is required by the later waters that altered the carnallite to sylvite. This means that the carnallite was first deposited in reducing, perhaps shallow, brine then exposed to oxidizing, perhaps nonmarine, waters that altered it to red sylvite.

Much more might be learned by closer study of the clastic sediments at Site 546, particularly to determine any aeolian and fluviatile contributions to the sediment.

\section{Marine, Modified Marine, and Nonmarine Inputs to} the Evaporites

The high values of $\mathrm{Br} / \mathrm{NaCl}$ (Table 1) indicate that the halides were substantially a first-cycle crystallization from seawater (e.g., Holser, 1979b). Minor recycling is indicated by values slightly lower than are customary for the potash facies. Similarly, a marine source is indicated for the salt at Tissa in the Pre-Rif of onshore Morocco for which two analyses of $\mathrm{Br} / \mathrm{NaCl}$ have been published (Kulke, 1978, p. 74). In contrast, the bromide data published for the Osprey evaporite from offshore Canada show a third of the values less than $20 \mathrm{ppm} \mathrm{Br} / \mathrm{NaCl}$, with most below $70 \mathrm{ppm}$. Jansa et al. (1980) correctly 
argue that this indicates partial dissolution. However, dissolution need not be by fresh water as they suggest, but could be by a new cycle of undersaturated seawater, although this seems unlikely in a basin so relatively distal to the probable inflow from the Tethys proposed by Jansa et al. (1980).

The stable isotope ratios of sulfate in the Site 546 core (Table 2) are consistent with a marine origin of the sulfate component of the brine only if the deposition took place in Permian or Scythian time. This date seems to be contradicted by a wide range of evidence, as discussed below and elsewhere in this volume, that points to Early Jurassic or, at most, a late Triassic age for the North Atlantic evaporites, their associated red bed sediments, and the rifting tectonics that gave rise to both. Could this mean that the evaporite is nonmarine in origin after all? Could contemporary riverine inputs of sulfur have decreased $\delta^{34} \mathrm{~S}$ in the rift valley?

In order to bring the $\delta^{34} \mathrm{~S}$ of the evaporite basin down from a Triassic-Jurassic value of $+17 \%$ to the depositional value of $+10 \%$, erosion of older marine evaporites into the basin would not be much help: the nearest older evaporites at that time were the Mississippian Windsor Group of Nova Scotia whose $\delta^{34} \mathrm{~S}$ was also high (Fig. 8) and even Permian evaporites would have had to contribute all of the Site 546 sulfate from sources at least as far distant as the southern Alps. Sulfate contributed by the erosion and oxidation of sulfide from shales or igneous rocks that lay within the drainage area of the rift during Triassic time might have contributed sulfate with $\delta^{34} \mathrm{~S}$, for example, near zero. Even that source would have had to nearly double the sulfate content of the basinal brine, but the Site 546 evaporates have no excess of sulfate beyond the few percent that must have inevitably flowed into the basin along with incoming waters (its dominantly marine origin is attested to by bromide geochemistry). Furthermore, the very large inflow of river water required to carry all that nonmarine sulfate would seem to be precluded by the high concentration of basin brines into the potash facies.

We also need to consider the possibility that the sulfur in this basin (as distinct from the water of the world oceans whose $\delta^{34} \mathrm{~S}$ is recorded in evaporites elsewhere) has been modified by the interaction of its brine with basalts of the rift valley through a hydrothermal circulation system such as that observed at present mid-ocean ridges (MOR) (e.g., Edmund et al., 1979). The literature concerning such systems is extensive but it will suffice to refer to the analysis by Shanks et al. (1981) that uses observations, laboratory experiments, and model calculations to monitor changes in the sulfur system during seawater-MOR interaction. The most obvious and immediate consequence for such interaction is isotopic fractionation of seawater sulfate during reduction to sulfide and its precipitation as pyrite at hydrothermal vents. The isotopic fractionation during reduction to sulfide leaves residual sulfate heavier by 10 to $20 \%$, as attested to by theoretical calculation, experiments on equilibrium fractionation (Shanks et al., 1981), kinetic fractionation (Kiyosu, 1980), and observation of ophiolite ore deposits. Edmund et al. (1979) called on this mecha- nism to raise $\delta^{34} \mathrm{~S}$ in present seawater to $+20 \%$, compared to $\delta^{34} \mathrm{~S} \simeq+10 \%$ of river water presently flowing into the oceans. The seawater that circulates in a seafloor hydrothermal system also has the capacity to dissolve pyrite from the basalts at $\delta^{34} \mathrm{~S} \simeq 0 \%$. Even if it were possible to keep this sulfide from reprecipitating at the vents and to reoxidize it in the seawater (by dissolved oxygen?), the amount of sulfide available in the basalts is insufficient (by one or more orders of magnitude) to bring down $\delta^{34} \mathrm{~S}$ in the evaporite basin sulfate. One can easily calculate that it would take all the sulfide in a section of basalt 5 or $10 \mathrm{~km}$ thick, working at optimum efficiency, to depress $\delta^{34} \mathrm{~S}$ in the brine that deposited, for example, $3 \% \mathrm{CaSO}_{4}$ in a $2 \mathrm{~km}$ section of evaporite rock. Finally, the evaporites of the Miocene Red Sea rift zone have $\delta^{34} \mathrm{~S}=+24 \%$ (Shanks et al., 1974), which is, if anything, slightly heavier than that in other (nonrift) evaporite occurrences of that age (Claypool et al., 1980). And modern coastal thermal waters generally have $\delta^{34} \mathrm{~S}$ equal to or slightly higher than that of modern seawater (Sakai and Matsubaya, 1974; Torssander, 1978).

Consequently, it is difficult to ascribe a major contribution of modified marine or nonmarine sulfur to the sulfate component of the evaporite, even in the face of the apparent anomaly of its $\delta^{34} \mathrm{~S}$ values.

Jansa et al. (1980) noted the curious absence of bedded anhydrite rocks in the Scotian Basin; we have found the same thing both offshore and onshore Morocco. Kulke $(1978$, p. 74$)$ also found only $3 \%$ or less of insoluble residue in two samples analyzed from Tissa, Morocco, and found few anhydrite beds elsewhere. Jansa et al. (1980) postulated that the incoming seawater must have been deficient in $\mathrm{CaSO}_{4}$ by pre-precipitation in basins bordering Tethys, after the Richter-Bernburg model (1955). The point is well taken, although anhydrite facies rocks are not really required in the great thicknesses that usually occur as a result of remaining for a long time in the $\mathrm{CaSO}_{4}$ facies. For example, if a section of salt rocks $1 \mathrm{~km}$ thick accumulated in a basin initially of that depth, the basin would reach the halite facies with the evaporation of at least (no reflux) $11.5 \mathrm{~km}$ of seawater that should have deposited a basal anhydrite $7 \mathrm{~m}$ thick (Holser, 1979a, pp. 254, 266). This is not evident in the log available for the Scotian evaporite (Jansa et al., 1980), however, we have no information on the presence or absence of such a basal anhydrite in the offshore Morocco basin.

A more directly observable consequence of a $\mathrm{CaSO}_{4}$ deficiency in the incoming (sea) water is in the content of anhydrite in the salt rock itself. If the basinal brine is already concentrated into the halite facies, and continually refilled with seawater as it evaporates further, then it should continue to precipitate $\mathrm{CaSO}_{4}$ along with the halite. This will be evident as dispersions of anhydrite in the salt rock, perhaps concentrated seasonally. At today's composition of seawater, this would amount to about 4 wt \% anhydrite in the salt rock (Holser, 1979a, p. 213). Polyhalite in corresponding amounts could account for the $\mathrm{CaSO}_{4}$ in potash facies rocks. Pending detailed analysis, we can estimate on the bases of insoluble residues and thin section examination that the salt rock 
at Site 546 may be somewhat deficient in $\mathrm{CaSO}_{4}$. Corresponding information for the evaporite of the Scotian Basin is not available.

$\mathrm{A} \mathrm{CaSO}_{4}$ deficiency in a salt rock section does not necessarily require a subsidiary preconcentrating basin as postulated by Jansa et al. (1980). An excess fraction of the $\mathrm{CaSO}_{4}$ flowing into the basin in seawater may be precipitated near the inlet or in shallow regions of the basin (e.g., Richter-Bernburg, 1955), leaving thick basinal salt somewhat deficient in anhydrite. Furthermore, the calcium sulfate content of seawater may have varied by a factor of at least two, plus or minus, during the Phanerozoic (Holland, 1973; Claypool et al., 1980; Garrels and Lerman, 1981).

\section{Brine Depth and Its Relations to Sea Level}

Marine evaporite basins generally occur in three rather different milieus (e.g., Kendall, 1979): (1) shallowwater shallow basin, in which supertidal and intertidal evaporites (the $\mathrm{CaSO}_{4}$ facies predominates) accumulate near sea level as the basin slowly subsides; type example, the recent sabkhas of the Persian Gulf area; (2) deepwater deep basin, in which a pre-existing (marine or nonmarine) basin evaporates to high concentration but maintains its surface essentially at sea level and is quickly filled with marine evaporites (halite facies predominates); type example, the upper Permian Castile Formation of the Delaware Basin; and (3) shallow-water deep basin, in which a pre-existing basin evaporates without sufficient input to maintain its brine surface at sea level and is intermittently desiccated; type example, Miocene evaporates of the Mediterranean Basin. This classification poses two interrelated questions, i.e., in what depth of brine was the evaporite sediment deposited, essentially a question of sedimentary facies, and what was the elevation of the brine surface, essentially a question of structural geology.

Variance of the bromide profile in the core is not so great as to suggest repeated desiccation of the basin during the deposition of these particular salts. This feature of bromide profiles has never been quantified, but the core does not display the high and random variations displayed by desiccated sabkhas (Holser et al,. 1981) or playas (Holser, 1970), although it does not rise nearly as smoothly as the deep-water Zechstein 2 (e.g., Holser, 1979a).

The single example of chevron texture in halite found at 546-19-2, 33-35 cm suggests by its probable diurnal banding (Holser, 1979a, p. 280) that the brine was shallow enough at that time to "feel" a daily cycle of high and low evaporation, temperature, or gas evolution.

No subaerial sedimentation features were recognized in the claystone inclusions or in the salt rock itself, but in view of their highly deformed character probably few such features would be preserved.

It was suggested in the discussion of sedimentary facies that the red and brown colorations are more common in shallow shelf evaporites, whereas gray green to black sediments are generally found in deep basinal evaporites. The mixture of both in Site 546 salt rock suggests that it was deposited near the transition between these color facies, whose depth or distance from shore, however, have never been established.

The very presence of the potash facies at Site 546 itself suggests that the basin is not exceedingly deep. The extreme stage of evaporation, 65X seawater (Holser, 1979a, p. 255) required for the potash facies to develop, inhibits its attainment in a deep body of brine. The potash facies in the evaporite basins whose geology has been most thoroughly studied (Permian Salado of New Mexico, Permian Verkhnekamsk of the U.S.S.R., Permian Zechstein of Germany, Oligocene of the Rhine Valley, Miocene of Sicily) generally occur near the top of a halite facies section. Although the base of that section may have begun deposition in deep brine, it was filled nearly to sea level by the time potash minerals appeared. Nevertheless, most such potash deposits display a very regular mineral banding that would seem to preclude extensive subaerial exposure. None of the above evidence is definitive for brine depth of deposition of salt rock at Site 546. But the overall impression of depths of tens rather than hundreds or thousands of meters, although of clear importance for the conditions of evaporite deposition, is not very significant in comparison with the possible thousands (or at least hundreds) of meters by which this base of the rift graben may have differed from sea level. Whether or not the body of brine that may have been some tens of meters deep had its surface at sea level is difficult to determine. Evidence on this point is more apt to come from studies or modeling of geological structure than it is from petrology or geochemistry. We can only make the following deduction: if the evaporite was deposited in relatively shallow water in a deep basin (brine surface far below sea level) then, the lack of reflux should eventually bring the brine into the highest evaporation facies with deposition of minerals such as bischofite or tachyhydrite. These have not been observed, at least, not in this core.

\section{Deformation}

Geophysically determined deformation and sedimentation provide evidence for the timing and structural mode of the rise of the bedded evaporite rock into the salt dome (site chapter, this volume). Given the internal evidence of the salt core itself, two points may be added.

Much of the salt rock, when examined in thin section, shows grain boundaries (many outlined by clouds of fluid inclusions) that have a curved polygonal shape which is a product of recrystallization. This texture is typical of dome rock salt (Holser, 1979a, p. 282) which has been annealed at temperatures above $300^{\circ} \mathrm{C}$ (due to burial) that are necessary for its plastic flow (Handin and Hager, 1958). In contrast, the unusual feature of the salt rock at Site 546 is a superimposed cataclastic texture that is easily seen in visual examination of the core, but is somewhat obscured when magnified in thin section. Broken and flattened crystals of halite give a preferred orientation parallel to the color banding or bedding of the rock. This feature indicates deformation at low temperatures after annealing. Such texture is commonly developed in salt rock masses that have taken part in near surface tectonic movements, usually associated with thrust 
faults, such as in the Pre-Rift salt masses of northern onshore Morocco (Tortochaux, 1968; Kulke, 1978), the Permo-Triassic Haselgebirge of the Austrian Alps (Schauberger, 1953); the Triassic diapirs of the Spanish Pyrenees (Brinkmann and Lötgers, 1968); and the Miocene of the Precarpathians of southern Poland (Garlicki, 1974). Another peculiarity is the nearly horizontal aspect of the banding of the salt in this core. Dome salt rock is typically so strongly deformed that it lies in nearly vertical isoclinal folds (e.g., Kupfer, 1968).

The "augen" texture that is evident in much of the core (Figs. 3-5) also originated in place immediately via the plastic or cataclastic flow of the finer grained surroundings of the augen. The ultimate origin of some other occurrences of Augensalz has been somewhat controversial. Based mainly on a consistently higher $\mathrm{Br}$ content in augen than in groundmass halite (in the Austrian Salzgebirge), Schauberger and Kühn (1959) were convinced that the augen had to be "descendent", that is, a detrital conglomerate transported from another deposit of higher facies evaporite sediment. Both Schwerdtner (1962) and Löffler (1962) failed to find such a consistent Br difference in the Zechstein of northern Germany, although neither proposed a full satisfactory origin of the texture. All these investigators seemed to agree that their augen grew as primary crystals during original sedimentation and were not porphyroblasts grown by metamorphic recrystallization under the influence of permeating brines. Although the implications of Schauberger and Kühn's hypothesis would be important for paleogeography, we did not consider it feasible to resolve this debate with the limited exposure available in this core.

Thus, although the cross section of the dome at Site 546 (Hinz, Winterer, et al., 1982, fig. 9; site chapter, this volume) suggests a simple nontectonic vertical diapir, the possibility should be entertained that it may be a tectonically related intrusion similar to the pre-Rif nappes known to occur about $100 \mathrm{~km}$ to the northwest of Site 546 (Malod, 1980). In the Punte Alegre diapir in northern Cuba, a similar situation of horizontal banding in salt cores also led to a suggestion of tectonic emplacement (Meyerhoff and Hatten, 1968, p. 346). The fact that the Site 546 mass is elongate in a northwest direction by a factor of at least three (Hinz, Winterer, et al., 1982, fig. 2; site chapter, this volume) is also suggestive of a Rif nappe. Such an origin would also explain why at least one of the nearby structures (Site 544) contains granitic rocks (Hinz, Winterer, et al., 1982; Site 544 site chapter, this volume).

Strong deformation in the formation of the Site 546 structure may also have complicated its internal constitution by entraining overlying sediments in the plastic salt rock during the rise of the diapir. Such entrainment of surrounding rocks, ranging in size from mineral grains to plucked blocks hundreds of meters in size have been abundantly observed in many diapir fields. In addition to the tectonically emplaced diapirs cited above, such xenoliths are also common in the Proterozoic Hormuz of Iran (Stöcklin, 1968, p. 164), the Carboniferous of the Canadian Arctic Islands (Gould and De Mille, 1968, p. 190), and the Jurassic of Tehuantepec, Mexico (Con- treras and Castillon, 1968, p. 249). At Site 546 the salt core itself does not furnish any direct evidence of xenoliths, but the early Cretaceous fossils mixed in the Miocene nannofossil ooze in Cores 546-16 and 546-17 (Hinz, Winterer, et al., 1982, p. 27; site chapter, this volume) may have been carried up in the salt rock and left as a solution residue on top of the dome (see discussion of cap rock below).

\section{Depositional Age}

The time of deposition of the original evaporite sedimentary beds is of critical importance in relation to the timing of rifting, subsidence, and continental separation. Direct radiometric dating of potash evaporite deposition would have been most informative, but our initial trial by this method was not successful.

Stable isotope composition of anhydrite and polyhalite in the evaporite rock is potentially useful in establishing dates of deposition of marine sulfate, with possible ambiguities depending on where the data fit to the isotope age curve (Fig. 3). In the present instance, the sulfur isotope ratios give a unique result of Permian to Scythian for the time that the sulfate left the world ocean. As discussed above in marine vs. nonmarine inputs, other explanations for the observed sulfur isotope ratios were considered in some detail. The conclusion was that other sources of sulfur are completely inadequate to account for the sulfur isotope data and that a PermianScythian marine input of seawater is required.

This conclusion contradicts widely held and strongly supported assertions that date the early action in the Atlantic Rift zone as generally late Triassic or Early Jurassic. Van Houten (1977), Manspeizer et al. (1978), and Jansa and Wiedmann (1982) have reviewed radiometric, palynological, and paleontological (invertebrate and vertebrate) data from onshore Morocco and generally agree on the following: (1) The oldest post-Carboniferous rocks, in the Oran Meseta and the High Atlas of eastern and central Morocco, are Ladinian carbonates and andesite flows and include some evaporites. However, according to R. DuDresnay (pers. comm. July, 1982), the andesites are more likely Permian. (2) At the western end of the High Atlas the Argana Valley section (Brown, 1980) continues upward into the Hettangian. The evaporites in the late Triassic part are suggested by Jansa and Wiedmann (1982, p. 236) to be continuous with the diapiric salts of the Essaouira Basin to the west (onshore and offshore). (3) In the coastal basins around the Moroccan Meseta (closest to Site 546), the earliest postCarboniferous sediments are Hettangian-Sinemurian clastics, evaporites, and basalts. North of the Gibraltar Fracture Zone, in the Lusitania Basin of Portugal, similar evaporites are also dated by fossiliferous interbedded carbonates as Hettangian-Sinemurian (Palain, 1976). In the present western Atlantic, salt rock drilled in the Scotian Basin is dated palynologically to range from Rhaetian to ?Sinemurian (Barss et al., 1979); farther offshore it may be older (Jansa and Wiedmann, 1982). On the Grand Banks/Flemish Basin (north of the fracture zone) the dates range from Carnian-Norian for the basal salt rock and underlying red beds to Hettangian- 
Sinemurian for the uppermost salt rock and overlying carbonates (Jansa et al., 1980).

Although this body of evidence is very compelling for a late Triassic to Early Jurassic sedimentation date for all evaporite rocks in the region, we note that the rocks on which it is based are those accessible on the flanks of the central Atlantic rift zone and in en echelon peripheral graben (Burke, 1976). Yet along the northward extension of the main rift direction, in and near the British Isles where the geology is better exposed, rift structures and their sedimentary fillings are found to be nearly continuous through the Permian and Triassic (e.g., Russell, 1976; Francis, 1978; Pegrum and Mounteney, 1978; Russell and Smythe, 1978; Ziegler, 1980). A Permian radiometric age in a rift on the eastern edge of the West African craton "may relate to a widescale episode of rifting in Pangea whose manifestations elsewhere include... Corsica, the North Sea and southern Norway." (Liegeois et al., 1983). Along the related rift of the Gulf of Mexico, a minority (Cebull and Sherbet, 1980) claim evidence that the Gulf remained partly open through the Permian-Triassic assembly of Pangea. These speculations are only to suggest that early in a rifting episode, as nearly all of the zone was undergoing typical uplift, erosion, and continental sedimentation (Bott, 1981; Scrutton, 1982), an initial narrow central graben may have dropped deep into these highlands. Given favorable conditions of structure and sedimentation, it might have been floored below sea level as Lake Tanganyika and Lake Baikal (Logatchev et al., 1978) are today. If an early rift valley of this sort had been formed in the Permian off northwest Africa, it may have had access to marine waters from the Tethys through the Gibraltar or South Atlas fracture zones (Burke, 1975; Van Houten, 1977; Bernoulli and Lemoine, 1980; Lancelot, 1980; Stets and Wurster, 1982). Perhaps this access was an incident in the Permian-Triassic shear of Pangea B into Pangea A proposed by Irving from paleomagnetic data (Morel and Irving, 1981). These are only provisional speculations that new information may confirm or deny.

It may be worth pointing out that the depositional age of the salt rock in the core at Site 546 is not necessarily the age of all evaporites in this structure: more than one age of salt is known to have taken part in single dome intrusions in Germany (Herrman et al., 1967) and in Iran (Stöcklin, 1968).

Definitive palynological results from Site 546, either from the salt core itself or from overlying residual material, would be an important consideration concerning the age of the evaporite and the above speculations on tectonics. A few small samples of shaley material collected from the salt core by W.T.H. were examined for palynomorphs by J. P. Bujak; only a few spores were recovered and these were "the same as in Canada" (L. F. Jansa, pers. comm., November, 1982). According to Martin Bradshaw (letter to E. L. Winterer, September, 1981), "Jim Fenton of Robertson Research here in the UK looked at one of my clay samples for palynology-the occurrence of Perinopollenites elatoides means the salt is no older than Rhaetian, and an abundance of Corollina meyeriana, by comparison with offshore eastern Cana- da, suggests Rhaetian-Hettangian." Although this may seem conclusive, the possible tectonic inclusion of younger rocks (as discussed in the previous section) should not be overlooked. Palynomorphs of Albian-Cenomanian age are found in salt of Jurassic (at least pre-Barremian) age in Tehuantepec, Mexico (Contreras and Castillon, 1968, p. 249), and palynomorphs of Oligocene age (Wilson, 1975; 1977) are found in the Jurassic salt of the Gulf Coast.

Clearly, further work needs to be done before a final decision is made on the age of the Site 546 evaporites and the tectonics that are related to their deposition. Further palynological studies would be desirable. These should include material from the core immediately above the salt contact where shaley components of the salt may have been concentrated and the yield of palynomorphs enhanced. They should also be made on splits of salt samples in which the same sample is analyzed for $\delta^{34} \mathrm{~S}$ and in which thin section studies establish an intimate relation (within claystone fragments) of anhydrite and the clay that presumably carries the palynomorphs. New trials of $\mathrm{Rb} / \mathrm{Sr}$ dating on potash rocks from both Site 546 and onshore Morocco, if successful, will certainly be helpful. Analyses will also be made of ${ }^{87} \mathrm{Sr} /$ ${ }^{86} \mathrm{Sr}$ in anhydrite and polyhalite, which are distinctive for seawater of the two ages in question (Burke et al., 1982). Sulfur isotope analyses of salt rock samples from onshore Morocco, from Portugal, and from offshore Canada, all now under way, will contribute cogent data.

\section{Erosion and Cap Rock}

Interpretation of seismic stratigraphy indicates salt movement started at Site 546 in the Early Cretaceous and it was still rising more or less uniformly from the early Miocene to the present time (site chapter, this volume). Recent movement is demonstrated by the fact that the top of salt is about $150 \mathrm{~m}$ above the off-structure sea floor (site chapter, this volume). These amounts of salt rock intrusion suggest an indeterminantly large amount of solution of salt from the top of the dome as it neared the seafloor. Presently active solution is shown by steady salinity and chlorinity gradients from the seawater-sediment interface down to the top of salt (Gieskes et al., this volume).

Salt domes that have been this active so recently are mostly topped by a cap rock some tens of meters thick, composed of residual anhydrite and clay, and secondary gypsum, calcite, and sulfur (e.g., Martinez, 1980). What we see at Site 546 in place of the usual cap rock is a section of about $7 \mathrm{~m}(546-17-3,75 \mathrm{~cm}$ to top of salt) of grayish red to brown silty claystone, composed mainly of clay-sized material 'with about $20 \%$ quartz silt. The barrel description (this volume) mentions a $4 \mathrm{~cm}$ bed of coarsely crystalline anhydrite in 546-18-1, but W.T.H. could not locate such a bed when sampling the cores. Minor gypsum was observed and one sample of this gypsum (Table 2, 546-18-1, 86-88 cm) has $\delta^{34}$ S only slightly higher than anhydrite in the underlying salt rock.

We can conclude with certainty that this gypsum was derived from the salt rock, probably by the hydration of anhydrite residual to salt solution, but possibly through 
solution and redeposition of calcium sulfate that was similarly derived from anhydrite in the salt rock. The fact that $\delta^{34} \mathrm{~S}$ has been little raised indicates not much if any activity of the sulfur reducing bacteria that commonly attack cap rock sulfate and generate calcite and sulfur (Feely and Kulp, 1957).

In contrast to the overlying nannofossil ooze, this $7 \mathrm{~m}$ section immediately overlying the salt rock is nonfossiliferous and of a darker color. It is probably proxy for cap rock, being mainly composed of the red clay and silt that are a prominent component of the salt rock. Although only a small amount of calcium sulfate was observed visually in this section, further analysis (by XRD, thin section, or chemistry) may show that some of the clay-size material in it is calcium sulfate, corresponding to the appreciable amount of fine-grained anhydrite seen in thin section in the salt rock.

The overlying nannofossil ooze in Cores 546-16 and 546-17 also includes clasts with Early Cretaceous microfossils; these also are possibly residual from salt rock xenoliths.

\section{CONCLUSIONS}

This initial study of the evaporites at Site 546 has established that those in the core are in the potash facies, as are some evaporites onshore in Morocco. Bromide geochemistry has demonstrated that the salts are predominantly marine in origin. They were deposited from brine that may not have been very deep, but was not intermittently desiccated. Sea level continuity into the ba$\sin$ is suggested by the observed mineralogy. The reddish claystone immediately overlying the top of salt is probably equivalent to a residual cap rock, reflecting the large amount of clay that dominates the insoluble fraction of the salt rock.

A major conclusion of the geochemical study is that the sulfur isotope ratio in the anhydrite of the salt rock (and the overlying cap rock) is derivative from seawater of Permian to Scythian age. This seems to contradict a wide range of evidence for a late Triassic to Early Jurassic age for evaporites all around the North Atlantic. But early formation of a narrow graben in the main rift zone may have allowed access of Tethyan seawater through the Gibraltar or South Atlas fracture zones. Studies under way on palynology, radiometric dating, and sulfur and strontium isotope ratios of other North Atlantic evaporites may either resolve these questions or leave us with even more questions.

A late cold cataclasis in the salt rock as well as the shape of the intrusion suggests a Pre-Rif tectonic intrusion rather than a simple, vertically buoyant, salt dome.

\section{ACKNOWLEDGMENTS}

Principal support for this research came from U.S. National Science Foundation Grant OCE 8200221 and from the Caswell Silver Foundation at the University of New Mexico. Field work by W.T.H. in evaporites onshore in Morocco and Portugal, which contributed to the interpretations of the evaporites at Site 546, was also supported by National Geographic Society Grant $2427-82$. That work benefited greatly from field assistance of Gail Peretsman and the friendly cooperation of the Service Geologique du Maroc, ONAREP, BRPM, Servicos Geológicos de Portugal, and many of their personnel.
Chemical analyses were precisely and efficiently done by Amy Shen and Christine McBirney. Some X-ray diffraction analyses were performed by Lance Peterson. The several difficulties in preparing thin sections of potash facies rocks were ably handled by Ken Gartner of the U.S. Geological Survey's laboratories at the Federal Center, Denver. Illustrations were carefully made by Judy Salas.

\section{REFERENCES}

Amadé, E., 1965. Le gisement de potasse de Khémisset. Mines Geol. (Rabat), 23:35-48.

Armstrong, R. L., 1978. Pre-Cenozoic Phanerozoic time scale-computer file of critical dates and consequences of new and in-progress decay-constant revisions. Am. Assoc. Pet. Geol. Stud. Geol, 6: 73-91.

Bailey, S. A., and Smith, J. W., 1972. Improved method for the preparation of $\mathrm{SO}_{2}$ form $\mathrm{BaSO}_{4}$ for isotope ratio studies. Anal. Chem., 44:1542-1543.

Barss, M. S., Bujak, J. P., and Williams, G. L., 1979. Palynological Zonation and Correlation of Sixty-seven Wells, Eastern Canada. Geol. Surv. Can. Pap., 78-24.

Bernoulli, D., and Lemoine, M., 1980. Birth and early evolution of the Tethys: the overall situation. Mem. Bur. Rech. Geol. Min., 115: 168-179.

Bott, M. H. P., 1981. Crustal doming and the mechanism of continental rifting. In Illies, J. H. (Ed.), Mechanism of Graben Formation: Amsterdam (Elsevier), 1-8.

Braitsch, O., 1961. Zur Kristallographie von Polyhalit. Beitr. Mineral. Petrog., 8:84-91.

Brinkmann, R., and Lötgers, H., 1968. Diapirs in western Pyrenees and foreland, Spain. In Braunstein, J., and O'Brien, G. D. (Eds.), Diapirism and Diapirs. Am. Assoc. Pet. Geol. Mem., 8:275-292.

Brookins, D. G., 1980. Polyhalite K-Ar radiometric ages from southeastern New Mexico. Isochron/West, 29:29-30.

Brookins, D. G., Register, J. K., Jr., and Krueger, H. W., 1890. Potassium-argon dating of polyhalite in southeastern New Mexico. Geochem. Cosmochim. Acta, 44:635-637.

Brown, R. H., 1980. Triassic rocks of Argana Valley, Southern Morocco, and their regional structural implications. Am. Assoc. Pet. Geol. Bull., 64:988-1003.

Burke, K., 1975. Atlantic evaporites formed by evaporation of water spilled from Pacific, Tethyan, and Southern oceans. Geology, 3: 613-616.

1976. Development of graben associated with the initial ruptures of the Atlantic Ocean. Tectonophysics, 36:93-112.

Burke, W. H., Denison, R. E., Hetherington, E. A., Koepnick, R. B., Nelson, H. F., and Otto, J. B., 1982. Variation of seawater ${ }^{87} \mathrm{Sr} /$ ${ }^{86} \mathrm{Sr}$ throughout Phanerozoic time. Geology, 10:516-519.

Cebull, S. E., and Shurbet, D. H, 1980. The Ouachita belt in the evolution of the Gulf of Mexico. In Pilger, R. H., Jr. (Ed.), The Origin of the Gulf of Mexico and the Early Opening of the Central North Atlantic Ocean: Baton Rouge (Louisiana State University), 17-26.

Claypool, G. E., Holser, W. T., Kaplan, I. R., Sakai, H., and Zak, I., 1980. The age curves of sulfur and oxygen isotopes in marine sulfate and their mutual interpretation. Chem. Geol., 28:199-260.

Contreras V., H., and Castillon B., M., 1968. Morphology and origin of salt domes of Isthmus of Tehuantepec. In Braunstein, J., and O'Brien, G. D., (Eds.), Diapirism and Diapirs. Am. Assoc. Pet. Geol. Mem., 8:244-260.

Edmond, J. M., Measures, C., McDuff, R. E., Chan, L. H., Collier, R., Grant, B., Gordon, L. I., and Corliss, J. B., 1979. Ridge crest hydrothermal activity and the balances of major and minor elements in the ocean: The Galapagos data. Earth Planet. Sci. Lett., 46:1-18.

Es-Said, S. I., 1974. Brom-Untersuchungen zur Genese des Schwadensalzes (Zechstein 3) im Bereich Hannover. Geol. Jahrb., D6.

Evans, R., 1978. Origin and significance of evaporites in basins around Atlantic margin. Am. Assoc. Pet. Geol. Bull., 62:223-234.

Feely, H. W., and Kulp, J. L., 1957. Origin of Gulf Coast salt-dome sulphur deposits. Am. Assoc. Pet. Geol. Bull., 41:1802-1853.

Francis, E. H., 1978. The Midland Valley as a rift, seen in connection with the late Palaeozoic European rift system. In Ramberg, I. B., and Neumann, E.-R. (Eds.), Tectonics and Geophysics of Continental Rifts: Dordrecht (Reidel), 133-147. 
Garlicki, A., 1974. Miocene salt deposits in Poland. In Coogan, A. (Ed.), Fourth Symposium on Salt (Vol. 1): Cleveland (Northern Ohio Geological Society), 129-134.

Garrels, R. M., and Lerman, A., 1981. Phanerozoic cycles of sedimentary carbon and sulfur. Proc. Natl. Acad. Sci., 78:4652-4656.

Glennie, K. W., 1970. Desert Sedimentary Environments: Amsterdam (Elsevier).

Goldman, E., and Byles, D., 1959. Suggested revision of phenol red method for bromide. Am. Water Works Assoc. J., 51:1051-1053.

Gould, D. B., and De Mille, G., 1968. Piercement structure in Canadian Arctic islands. In Braunstein, J., and O'Brien, G. D. (Eds.), Diapirism and Diapirs. Am. Assoc. Pet. Geol. Mem., 8:183-214.

Handin, J., and Hager, R. V., Jr., 1958. Experimental deformation of sedimentary rocks under confining pressure; pt. 2, Tests at high temperature. Am. Assoc. Pet. Geol. Bull., 42:2892-2934.

Haworth, R. T., and Keen, C. E., 1979. The Canadian Atlantic margin: A passive continental margin encompassing an active past. Tectonophysics, 59:83-126.

Hay, W. W., Behensky, J. R., Jr., Barron, E. J., and Sloan, J. L., II, 1982. Late Triassic-Liassic paleoclimatology of the north-central North Atlantic rift system. Palaeogeogr., Palaeoclimatol. Palaeoecol., 40:13-30.

Herrmann, A., Hinze, C., Stein, V., and Nielsen, H., 1967. Die halotektonische Deutung der Elfas-überschiebung im südniedersächsischen Bergland. Geol. Jahrb., 84:407-472.

Hinz, K., Dostmann, H., and Fritsch, J., 1982. The continental margin of Morocco: Seismic sequences, structural elements, and geological development. In von Rad, U., Hinz, K., Sarnthein, M., and Seibold, E. (Eds.), Geology of the Northwest African Continental Margin: Berlin (Springer-Verlag), 34-60.

Hinz, K., Winterer, E. L., Baumgartner, P. O., Bradshaw, M. J., Channel, J. E. T., Jaffrezo, M., Jansa, L. F., Leckie, R. M., Morre, J., Rullkötter, J., Schaftenaar, C., Steiger, T. H., Vuchev, V., and Wiegand, G. E., 1982. Preliminary results from DSDP Leg 79 seaward of the Mazagan Plateau off Central Morocco. In von Rad, U., Hinz, K., Sarnthein, M., and Seibold, E. (Eds.), Geology of the Northwest African Continental Margin: Berlin (Springer-Verlag), 23-33.

Holland, H. D., 1974. Marine evaporites and the composition of seawater during the Phanerozoic. In Hay, W. W. (Ed.), Studies in Paleo-Oceanography. Soc. Econ. Paleontol. Mineral. Spec. Publ., 20:187-192.

Holser, W. T., 1966. Diagenetic polyhalite in Recent salt from Baja California. Am. Mineral., 51:99-109. 1970. Bromide geochemistry of some nonmarine salt deposits in the southern Great Basin. Mineral. Soc. Am. Spec. Pap., 3:307-319.

1979a. Mineralogy of evaporites. Mineral. Soc. Am. Rev. Mineral., 6:211-294.

1979b. Trace elements and isotopes in evaporites. Mineral. Soc. Amer. Rev. Mineral., 6:295-346.

Holser, W. T., Hay, W. W., Jory, D. E., and O'Connell, W. J., 1980. A census of evaporites and its implications for oceanic geochemistry. Geol. Soc. Am. Abstr. Prog., 12:449.

Holser, W. T., Javor, B. J., Pierre, C., and Ortlieb, L., 1981. Geochemistry and ecology of salt pans at Guerrero Negro, B.C.S. In Ortlieb, L., and Roldan, Q. J. (Eds.), Geology of Northwestern Mexico and Southern Arizona: Mexico (Instituto de Geologia, U.N.A.M.), 1-56.

Holser, W. T., and Kaplan, I. R., 1966. Isotope geochemistry of sedimentary sulfates. Chem. Geol., 1:93-135.

Holser, W. T., Kaplan, I. R., Sakai, H., and Zak, I., 1979. Isotope geochemistry of oxygen in the sedimentary sulfate cycle. Chem. Geol., 25:1-17.

Holt, B. D., and Engelkemeir, A. G., 1970. Thermal decomposition of $\mathrm{BaSO}_{4}$ to $\mathrm{SO}_{2}$ for mass spectrometric analysis. Anal. Chem., 42:451-453.

Jansa, L. G., Bujak, J. P., and Williams, G. L., 1980. Upper Triassic salt deposits of the western North Atlantic. Can. J. Earth Sci., 17: 547-559.

Jansa, L. F., and Wiedmann, J., 1982. Mesozoic-Cenozoic development of the eastern North American and northwest African conti- nental margins: A comparison. In von Rad, U., Hinz, K., Sarnthein, M., and Seibold, E. (Eds.) Geology of the Northwest African Continental Margin: Berlin (Springer-Verlag), 215-269.

Kendall, A. C., 1979. Facies models 14. Subaqueous evaporites. In Walker, R. G. (Ed.), Facies Models: Waterloo, Ontario (Geological Assoc. Canada), 159-174.

Kirchheimer, F., 1976. Blaues Steinsalz und sein Vorkommen im Neckar- und Oberrheingebeit. Geol. Jahrb., D18.

Kiyosu, Y., 1980. Chemical reduction and sulfur-isotope effects of sulfate reduction by organic matter under hydrothermal conditions. Chem. Geol., 30:47-56.

Kühn, R., 1968. Geochemistry of the German potash deposits. Geol. Soc. Am. Spec. Pap., 88:427-504.

Kuehn, R., and Hsü, K. J., 1978. Chemistry of halite and potash salt cores, DSDP Sites 374 and 376, Leg 42A, Mediterranean Sea. In Hsü, K., Montadert, L., et al., Init. Repts. DSDP, 42, Pt. 1: Washington (U.S. Govt. Printing Office), 613-619.

Kulke, H., 1978. Tektonik und Petrographie einer Salinar-formation am Beispiel der Trias des Atlassystems (NW-Afrika). Geotekt. Forsch., 55.

Kupfer, D. H., 1968. Relationship of internal and external structure of salt domes. In Braunstein, J., and O’Brien, G. D. (Eds.), Diapirism and Diapirs. Am. Ass. Pet. Geol. Mem., 8:79-89.

Lancelot, Y., 1980. Birth and evolution of the "Atlantic Tethys" (Central North America). Mem. Bur. Rech. Geol. Min., 115:215-223.

Lancelot, Y., and Winterer, E. L., 1980. Evolution of the Moroccan oceanic basin and adjacent continental margin-a synthesis. In Lancelot, Y., Winterer, E. L., et al., Init. Repts. DSDP, 50: Washington (U.S. Govt. Printing Office), 801-821.

Liegeois, J. P., Bertrand, H., Black, R., Caby, R., and Fabre, J., 1983. Permian alkaline undersaturated and carbonatite province, and rifting along the West African craton. Nature, 305:42-43.

Lippolt, H. J., 1977. Isotopische Salz-Datierung: Deutung und Bedeutung. Aufschluss, 28:369-389.

Lippolt, H. J., and Raczek, I., 1979. Cretaceous Rb-Sr total rock ages of Permian salt rocks. Naturwissenschaften, 66:422-423.

Löffler, J., 1962. Zur Genese der Augensalze im Zechstein der Deutschen Demokratischen Republik. Zeit. Angew. Geol., 11:583-589.

Logatchev, N. A., Rogozhina, V. A., and Solonenko, V. P., 1978. Deep structure and evolution of the Baikal rift zone. In Ramberg, I. B., and Neumann, E.-R., (Eds.), Tectonics and Geophysics of Continental Rifts: Dordrecht (Reidel), 49-61.

Lorenz, J., 1976. Triassic sediments and basin structure of the Kerrouchen Basin, central Morocco. J. Sed. Petrol., 46:897-905.

Malod, J.-A., 1980. La marge atlantique marocaine au Nord de Casablanca. Rev. Geol. Dynam. Geog. Phys., 22:201-212.

Manspeizer, W., Puffer, J. H., and Cousminer, H. L., 1978. Separation of Morocco and eastern North America: A Triassic-Liassic stratigraphic record. Geol. Soc. Am. Bull., 89:901-920.

Martinez, J. D., 1980. Salt dome cap rock-a record of geologic processes. In Coogan, A. H., and Hauber, L. (Eds.) Fifth Symposium on Salt (Vol. 1): Cleveland (Northern Ohio Geological Society), 143-152.

Meyerhoff, A. A., and Hatten, C. W., 1968. Diapiric structures in central Cuba. Am. Assoc. Pet. Geol. Mem., 8:315-357.

Morel, P., and Irving, E., 1981. Paleomagnetism and the evolution of Pangea. J. Geophys. Res., 86:1858-1872.

Nielsen, H., 1977. Sulfur isotopes. In Wedepohl, K. H. (Ed.) Handbook of Geochemistry: Berlin (Springer-Verlag).

Nielsen, H., and Ricke, W., 1964. Schwefel-Isotopen-Verhältrisse von Evaporiten ans Deutschland; ein Beitrag zur Kenntris von $\mathrm{S}^{34}$ in Meerwasser-Sulfate. Geochim. Cosmochim. Acta, 28:577-581.

Oesterle, F.-P., and Lippolt, H. J., 1975. Isotopische Datierung der Langbeinitbildung in der Kalisalz-lagerstätten des Fuldabeckens. Kali Steinsalz, 6:391-398.

Ortí Cabo, F., and Pueyo Mur, J. J., 1980. Polihalita diagenetica en una secuencia evaporitica continental (Miocena, Cuence del Tajo, Espana). Rev. Inst. Invest. Geol. [Barcelona], 34:209-222.

Palache, C., Berman, H., and Frondel, C., 1951. Dana's System of Mineralogy (Vol. 2, 7th ed.): New York (Wiley), 459.

Palain, C., 1976. Une série détritique terrigène les "Grès de Silves": Trias et Lias inférieur du Portugal. Mem. Serv. Geol. Portugal, 25. 
Pegrum, R. M., and Monteney, N., 1978. Rift basins flanking North Atlantic Ocean and their relation to North Sea area. Am. Assoc. Pet. Geol. Bull., 62:419-441.

Pilot, J., and Blank, P., 1967. K-Ar-Bestimmungen von Salz-gesteinen des Zechsteins. Zeit. Angew. Geol., 13:661-662.

Register, J. K., and Brookins, D. G., 1980. Rb-Sr isochron age of evaporite minerals from the Salado formation (Late Permian), southeastern New Mexico. Isochron/West, 29:39-42.

Ribeiro, A., Conde, L., and Monteiro, E. J. (coordinators), 1972. Carta Tectonica de Portugal, 1:1,000,000: Lisbon (Servicos Geologicos).

Richter, A., 1962. Die Rotfärbung in Salzen der deutschen Zechsteinlagerstatten. Chemie Erde, 22:508-546.

1964. Die Rotfärbung in Salzen der deutschen Zechsteinlagerstatten. II. Chemie Erde, 23:39-42.

Richter-Bernburg, G., 1955. Über salinär Sedimentation. Zeitschr. Deutsch. Geol. Gesell., 105:593-645. 1972. Saline deposits in Germany, a review and general introduction to the excursions; geology of saline deposits. UNESCO Earth Sci. Ser., 7:275-287.

Roeser, H. A., 1982. Magnetic anomalies in the magnetic quiet zone off Morocco. In von Rad, U., Hinz, K., Sarnthein, M., and Seibold, E. (Eds.), Geology of the Northwest African Continental Margin: Berlin (Springer-Verlag), 61-68.

Russell, M. J., 1976. A possible Lower Permian age for the onset of ocean floor spreading in the northern North Atlantic. Scott. J. Geol., 12:315-323.

Russell, M. J., and Smythe, D. K., 1978. Evidence for an early Permian oceanic rift in the northern North Atlantic. In Neumann, E. R., and Ramberg, I. B. (Eds.), Petrology and Geochemistry of Continental Rifts: Dordrecht (Reidel), 173-179.

Sakai, H., 1977. Sulfate-water isotope thermometry applied to geothermal systems. Geothermics, 5:67-74.

Sakai, H., and Krouse, H. R., 1971. Elimination of memory effect in ${ }^{18} \mathrm{O} /{ }^{16} \mathrm{O}$ determination in sulfates. Earth Planet. Sci. Lett., 11: 369.

Sakai, H., and Matsubaya, O., 1974. Isotopic geochemistry of the thermal waters of Japan and its bearing on the Kuroko ore solutions. Econ. Geol., 69:974-991.

Saltzman, E. S., Lindh, T. B., and Holser, W. T., 1982. Secular changes in $\delta^{13} \mathrm{C}$ and $\delta^{34} \mathrm{~S}$, global sedimentation, $\mathrm{pO}_{2}$, and $\mathrm{pCO}_{2}$ during the Phanerozoic. Geol. Soc. Am. Abstr. Prog., 14:607.

Salvan, H. M., 1974. Le séries salifères du Trias marocain; caractères généraux et possibilités d'interprétation. Bull. Soc. Geol. Fr., 16: 724-731.

Schauberger, O., 1953. Zur Genese des alpinen Haselgebirges. Zeit. Deutsch. Geol. Gesell., 105:736-751.

Schauberger, O., and Kühn, R. 1959. Über die Entstehung des alpinen Augensalzes. Neues Jahrb. Geol. Palaontol. Monatsh., 247-259.

Schilling, J. A., 1973. K-Ar dates on Permian potash minerals from southeastern New Mexico. Isochron/West, 6:37-38.

Schwerdtner, W., 1962. Untersuchungen an bunten Augensalzen in Ronnenberg Gruppe (Zechstein 3) von Hannover. Kali Steinsalz, 8: 265-275.

Scrutton, R. A., 1982. Passive continental margins: A review of observations and mechanisms. In Scrutton, R. A. (Ed.), Dynamics of Passive Margins: Washington (Am. Geophys. Un), 5-11.
Shanks, W. C., Bischoff, J. L., and Kaplan, I. R., 1974. Sulfur isotope studies of evaporites and shales from Sites 225, 227, and 228 in the Red Sea. In Whitmarsh, R. B., Weser, D. E., Ross, D. A., et al., Init. Repts. DSDP, 23: Washington (U.S. Govt. Printing Office), 947-950.

Shanks, W. C., III, Bischoff, J. L., and Rosenbauer, R. J., 1981. Seawater sulfate reduction and sulfur isotope fractionation in basaltic systems: Interaction of seawater with fayalite and magnetite at 200-350 ${ }^{\circ} \mathrm{C}$. Geochem. Cosmochim. Acta., 45:1977-1995.

Stets, J., and Wurster, P., 1982. Atlas and Atlantic-structural relations. In von Rad, U., Hinz, K., Sarnthein, M., and Seibold, E. (Eds.), Geology of the Northwest African Continental Margin: Berlin (Springer-Verlag), 69-85.

Stöcklin, J., 1968. Salt deposits of the Middle East. Geol. Soc. Am. Spec. Pap., 88:157-181.

Tixeront, M., 1971. Lithostratigraphie et minéralisations cuprifères et uranifères stratiformes syngénétiques et familières des formations détritiques permo-triassique du couloir d'Argana, Haut Atlas occidental (Maroc) et possibilites de recherches. Notes Serv. Geol. Maroc, 33:147-177. 921.

Torssander, P., 1978. Sulfur isotopes in Icelandic geothermal waters: An interim report. Ann. Rept. Ore Res. Group Stockholm Univ., pp. 85-96.

Tortochaux, F., 1968. Occurrence and structure of evaporites in North Africa. Geol. Soc. Am. Spec. Pap., 88:107-138.

Van Houten, F. B., 1977. Triassic-Liassic deposits of Morocco and eastern North America. Am. Assoc. Pet. Geol. Bull., 61:79-99.

Walker, T. R., 1967. Formation of red beds in ancient and modern deserts. Geol. Soc. Am. Bull., 85:633-638.

Westphal, M., Montigny, R., Thuizat, R., Bardon, C., Bossert, A., Hamseh, R., and Rolley, J. P., 1979. Paléomagnétisme et datation du volcanisme permien, triasique et crétacé du Maroc. Can. J. Earth Sci., 16:2150-2164.

Wilson, H. H., 1975. Sub salt origin of exotic blocks in piercement domes reveals the probability of Oligo-Miocene salt in the Gulf of Mexico region. Gulf Coast Ass. Geol. Soc. Trans., 25:1-19. 1977. Shear zones inside Gulf Coast salt stocks help to delineate spines of movement: Discussion. Am. Ass. Pet. Geol. Bull., 61:1090-1091.

Winchell, A. N., and Winchell, H., 1951. Elements of Optical Mineralogy (part II, 4th ed.): New York (Wiley).

Wissmann, G., and Roeser, H. A., 1982. A magnetic and halokinetic structural Pangaea fit of northwest Africa and North America. Geol. Jahrb., E23:43-61.

Zbyszewski, G., 1959. Etude strucutrale de l'aire typhonique de Caldas da Rainha. Mem. Serv. Geol. Portugal, n.s., 3.

Zharkov, M. A., 1981. History of Paleozoic Salt Accumulation: Berlin (Springer-Verlag).

Ziegler, P. A., 1980. Northwestern Europe: Subsidence patterns of post-Variscan basins. Mem. Bur. Rech. Geol. Min., 108:249-280.

Date of Initial Receipt: January 14, 1983

Date of Acceptance: December 9, 1983 


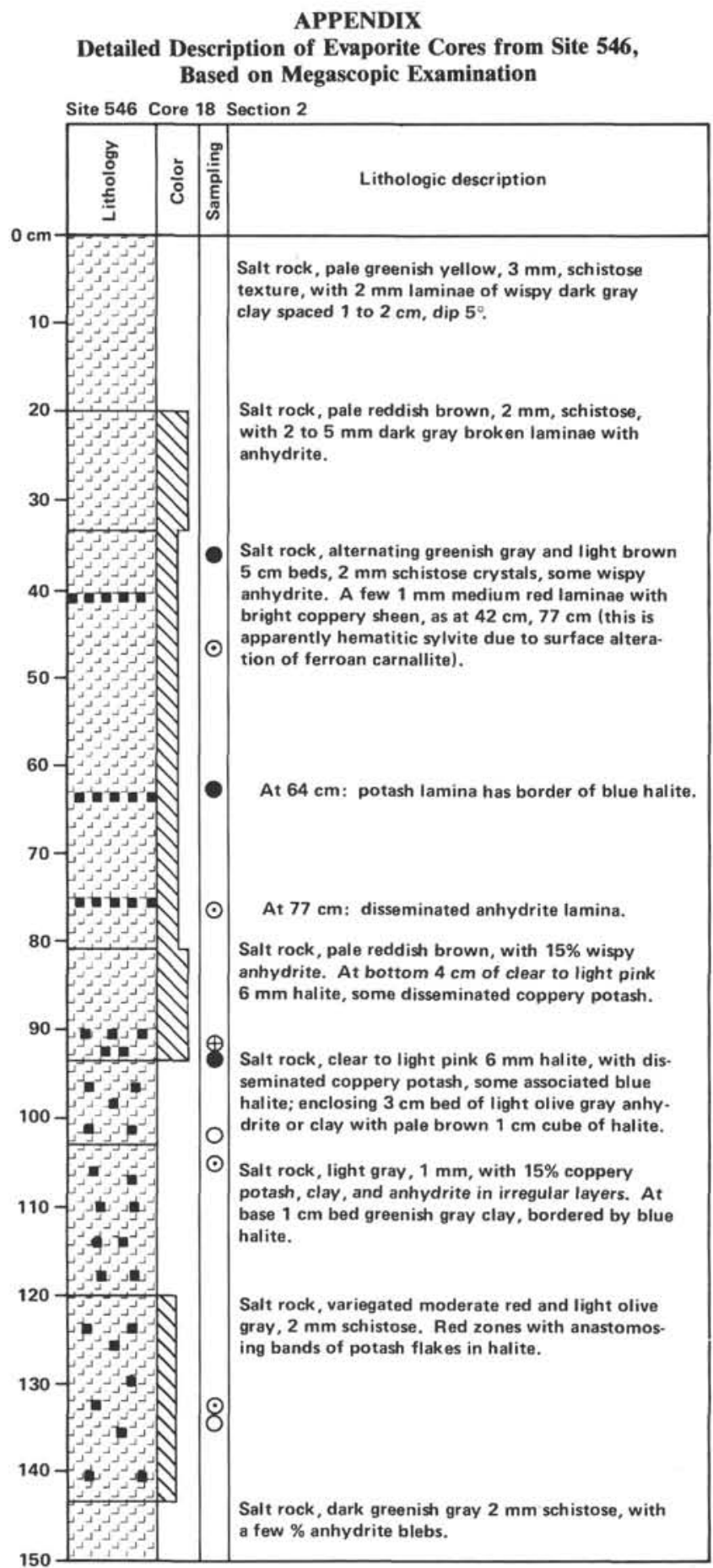

Appendix. (Continued).

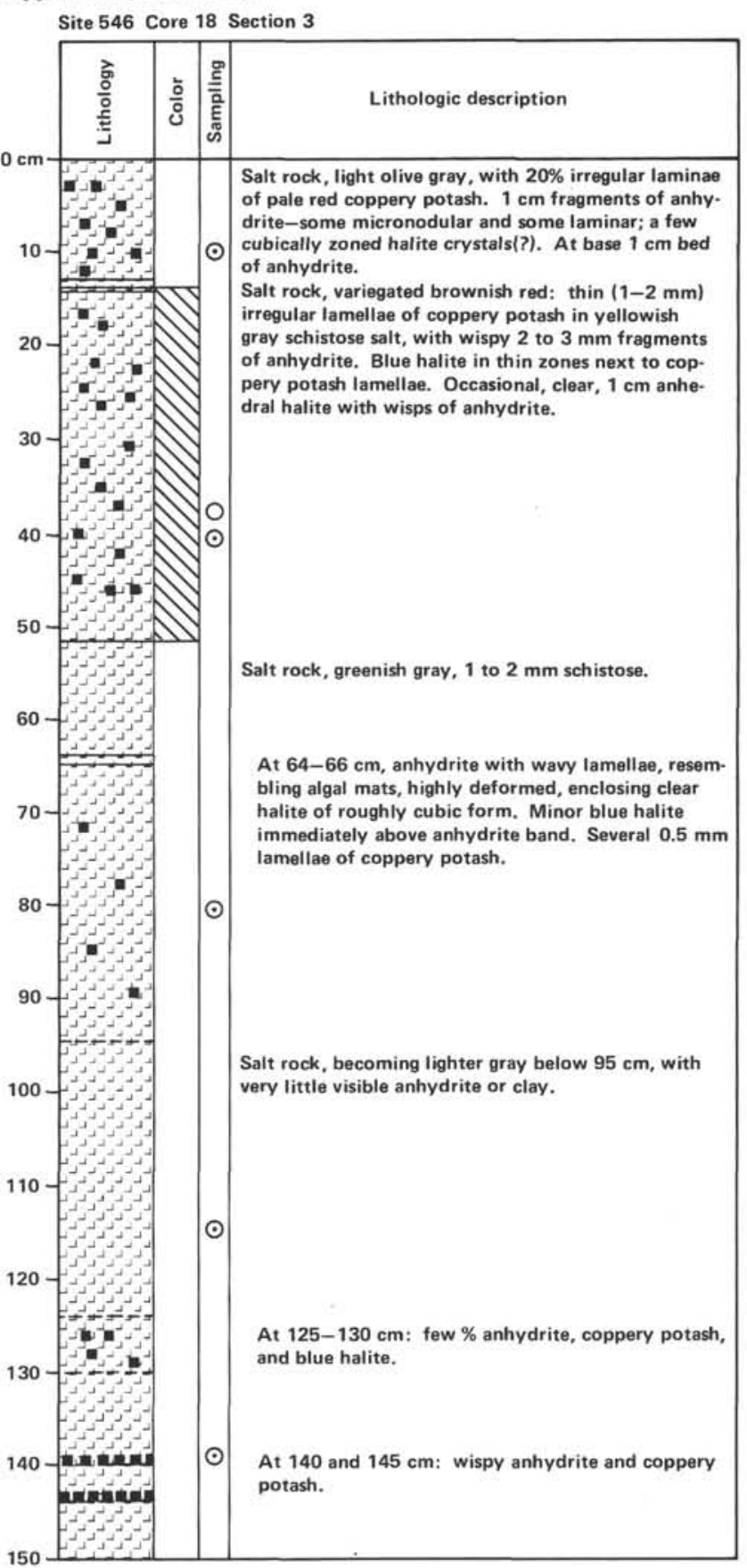

Sait rock, greenish gray, 1 to $2 \mathrm{~mm}$ schistose.

At $64-66 \mathrm{~cm}$, anhydrite with wavy lamellae, resembling algal mats, highly deformed, enclosing clear halite of roughly cubic form. Minor blue halite immediately above anhydrite band. Several $0.5 \mathrm{~mm}$ lamellae of coppery potash.

$60-$
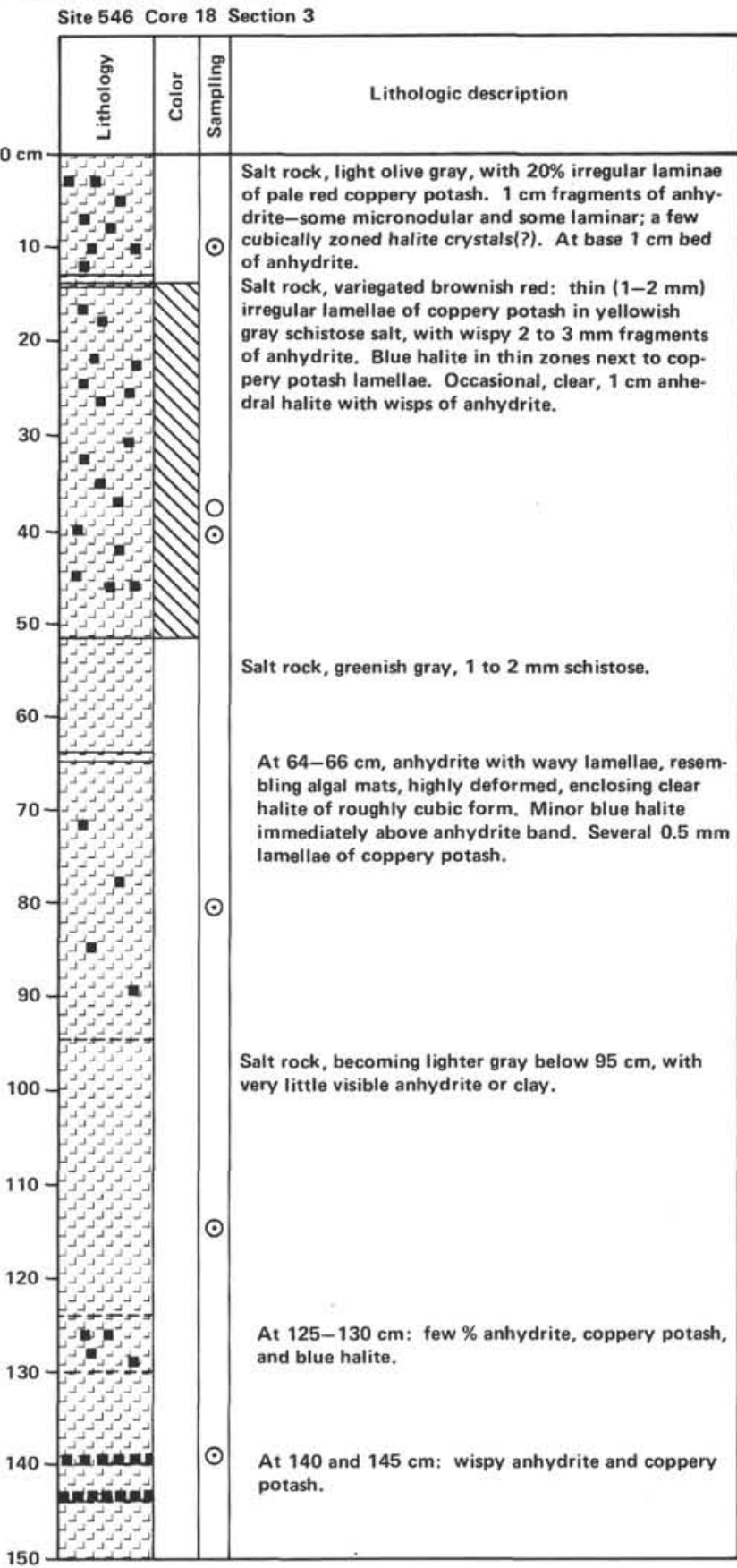

alt rock, becoming lighter gray below $95 \mathrm{~cm}$, with very little visible anhydrite or clay.

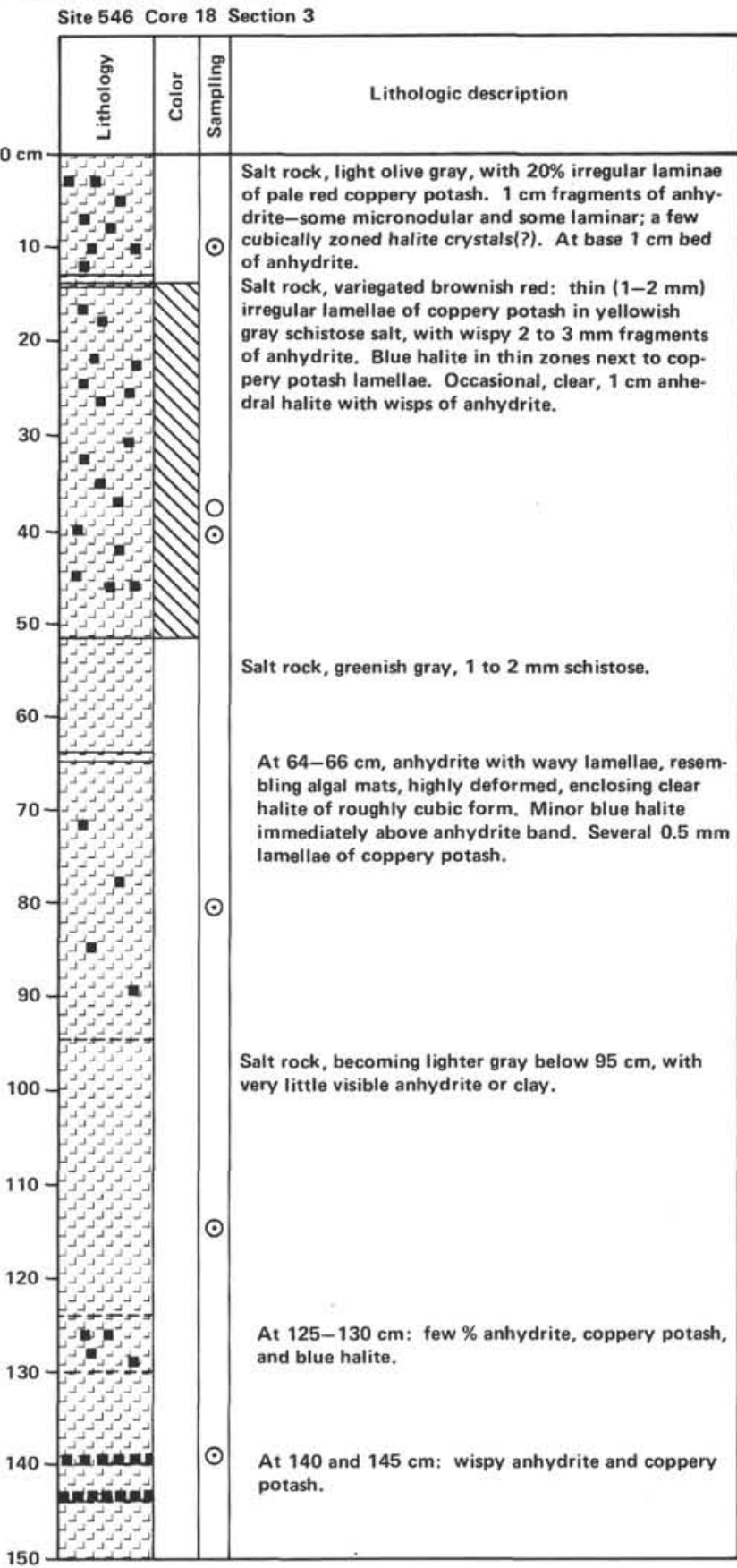
and blue halite.

150

\begin{tabular}{|c|c|c|c|c|}
\hline & Lithology & Color & & \\
\hline ] & Salt rock & $\begin{array}{l}\text { Reduced sediments } \\
\text { (green, gray, colorless) }\end{array}$ & $\odot$ & $\begin{array}{l}\text { Chemical analysis } \\
\text { of channel samples }\end{array}$ \\
\hline च & Potash rock & $\begin{array}{l}\text { Oxidized sediments } \\
\text { (red, brown, yellow) }\end{array}$ & $\oplus$ & $\begin{array}{l}\text { Chemical analysis } \\
\text { of spot samples }\end{array}$ \\
\hline & Anhydrite rock & Sampling & & $\begin{array}{l}\text { Sulfur isotope } \\
\text { analysis }\end{array}$ \\
\hline$=-7$ & $\begin{array}{l}\text { Siltstone or } \\
\text { claystone }\end{array}$ & Thin section & 0 & Radiometric dating \\
\hline
\end{tabular}


Appendix. (Continued).

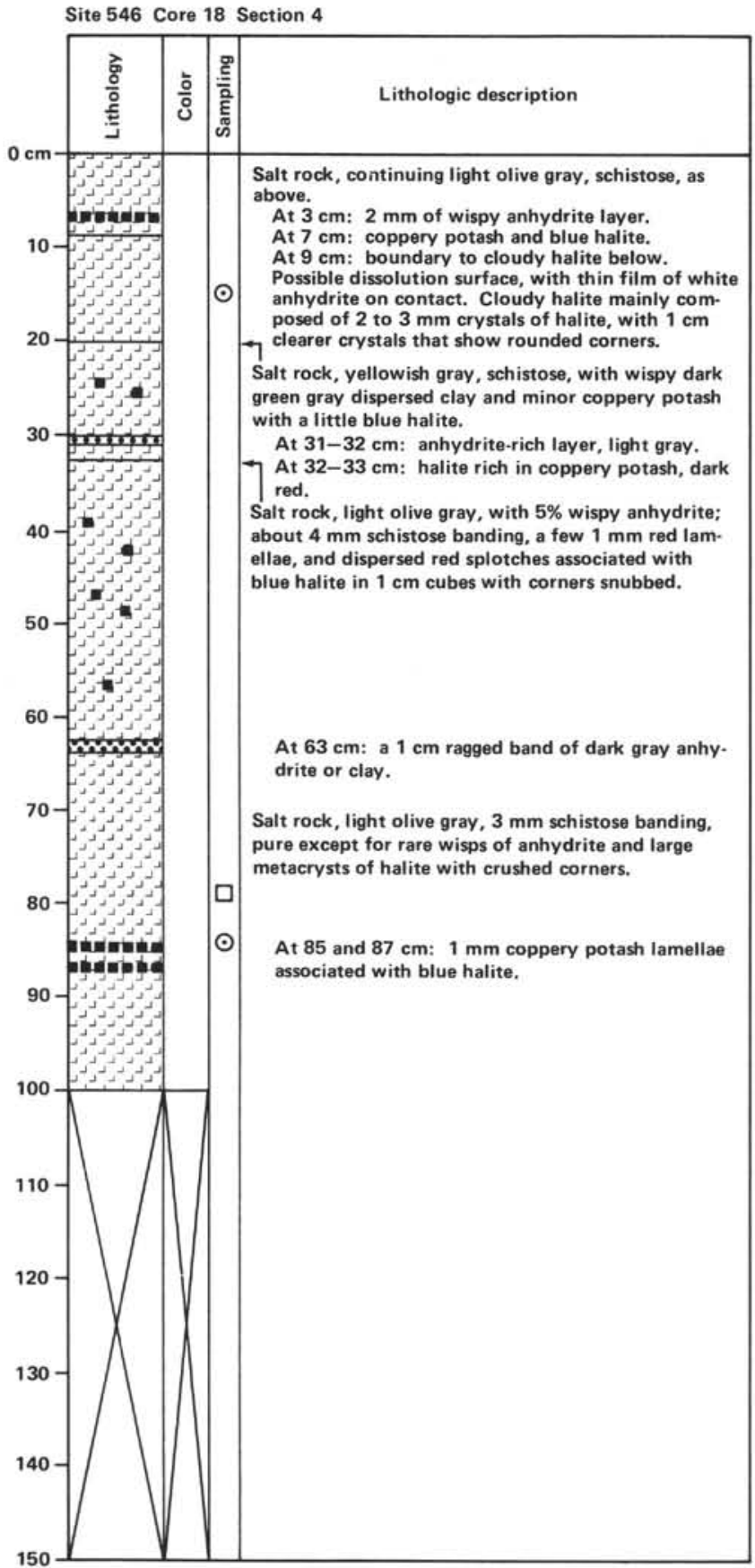

Appendix. (Continued).

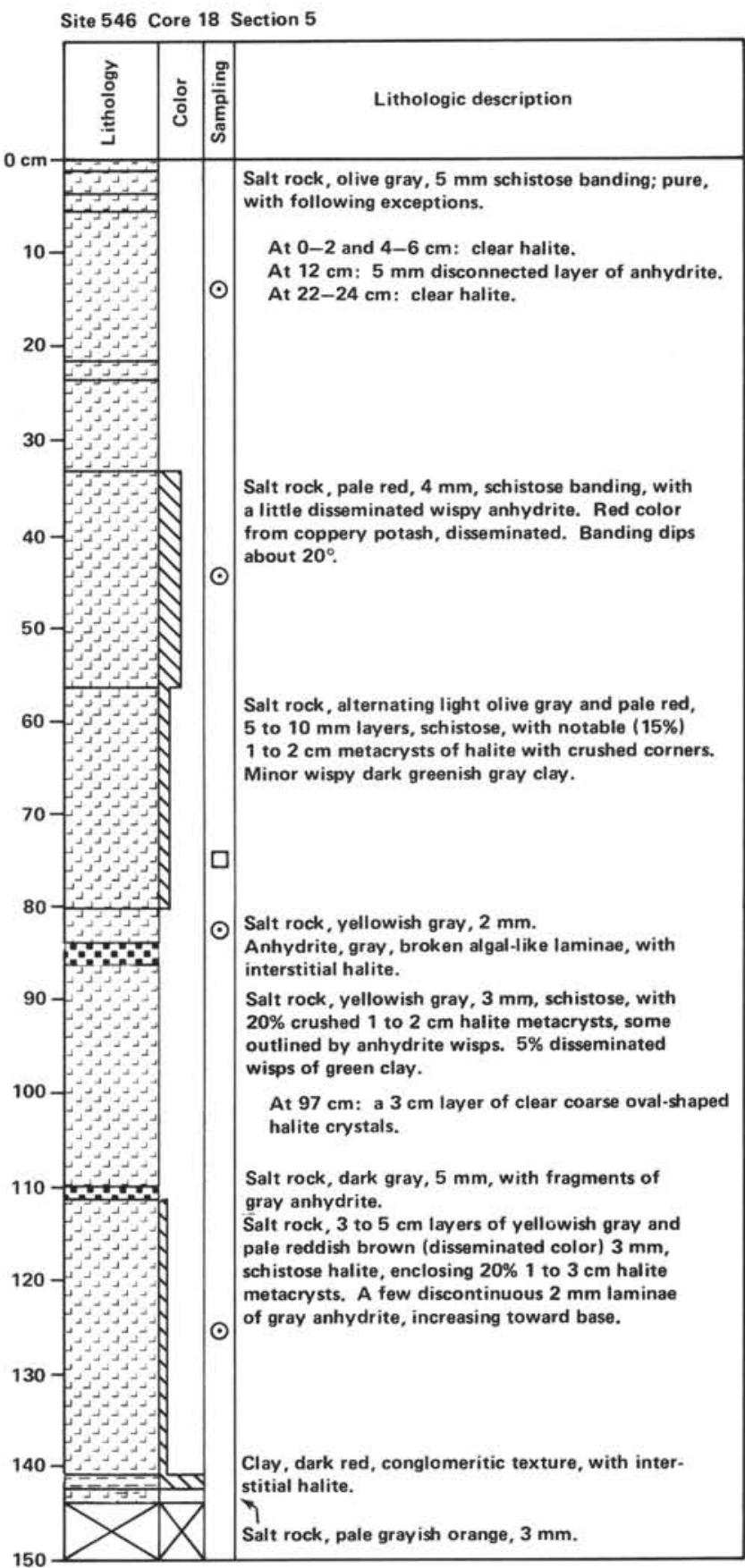


Appendix. (Continued).

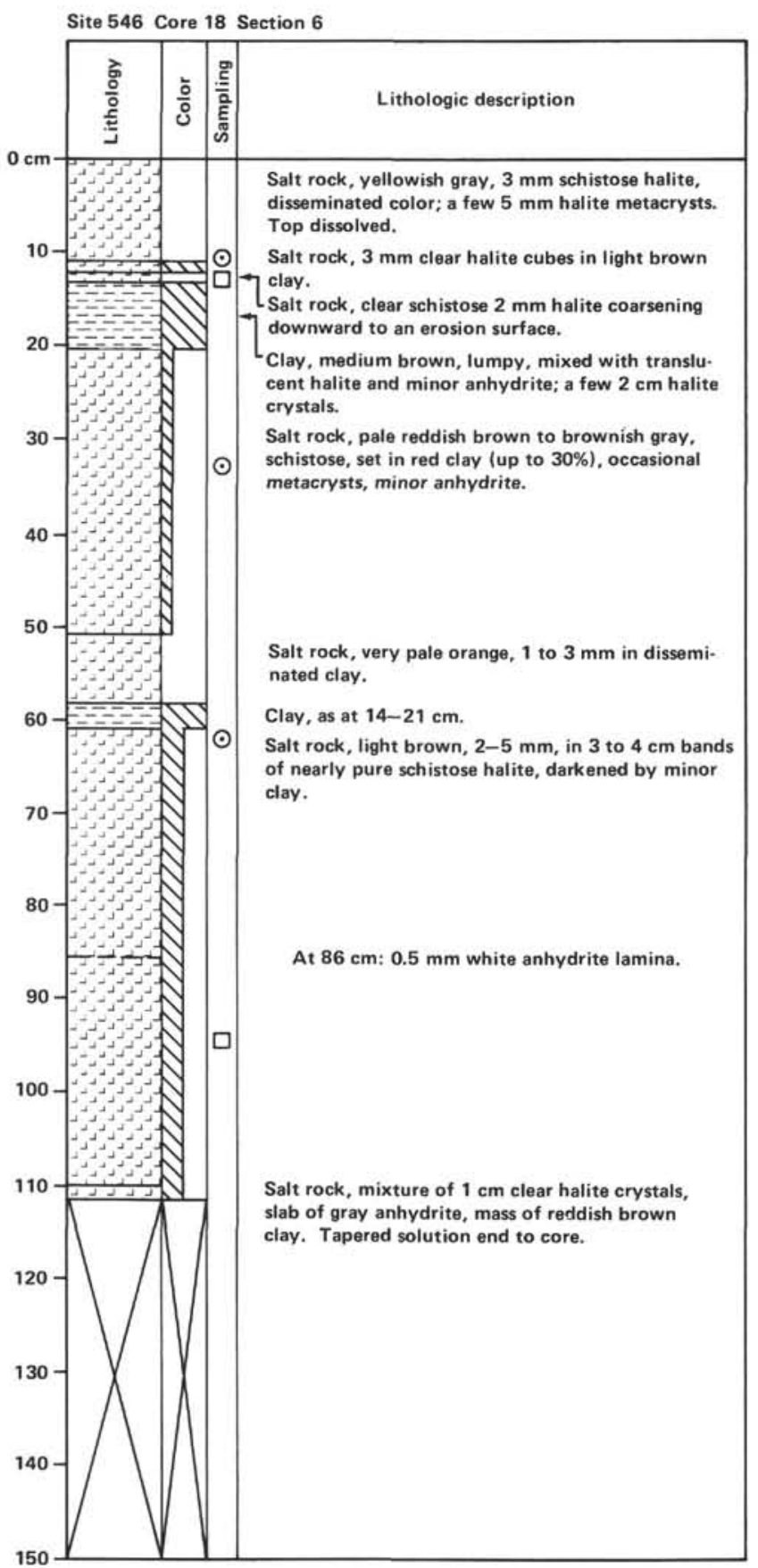

Appendix. (Continued).

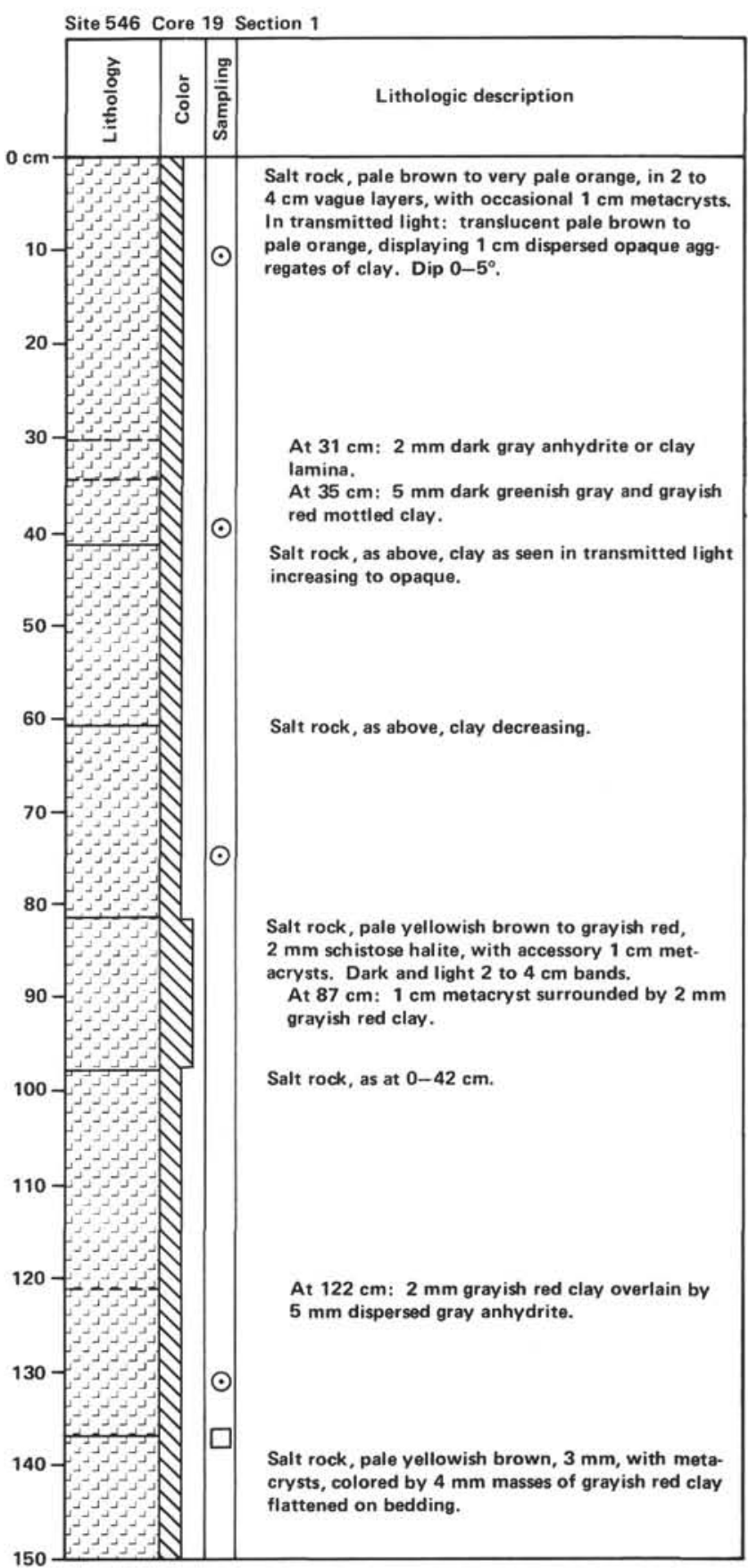


Appendix. (Continued).

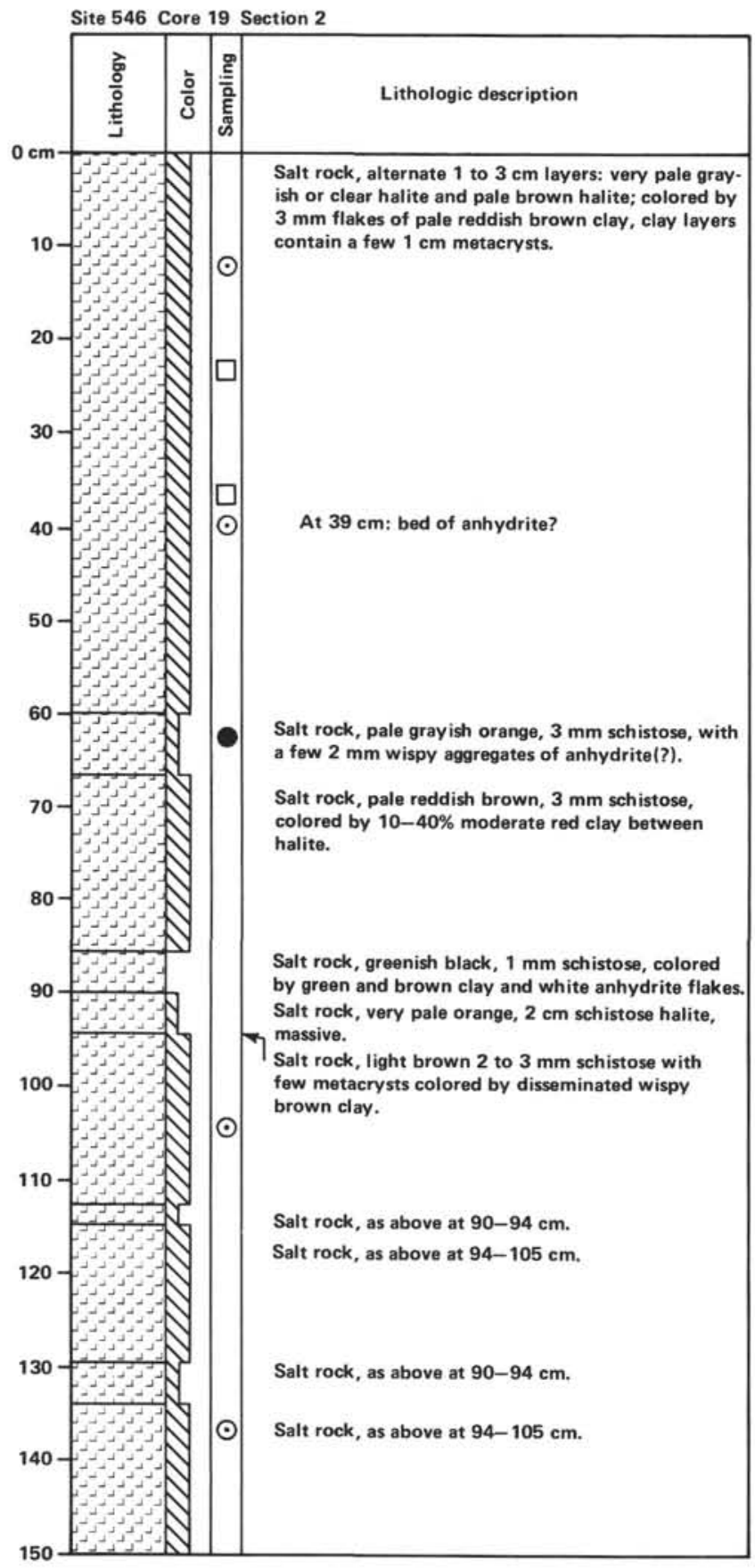

Appendix. (Continued).

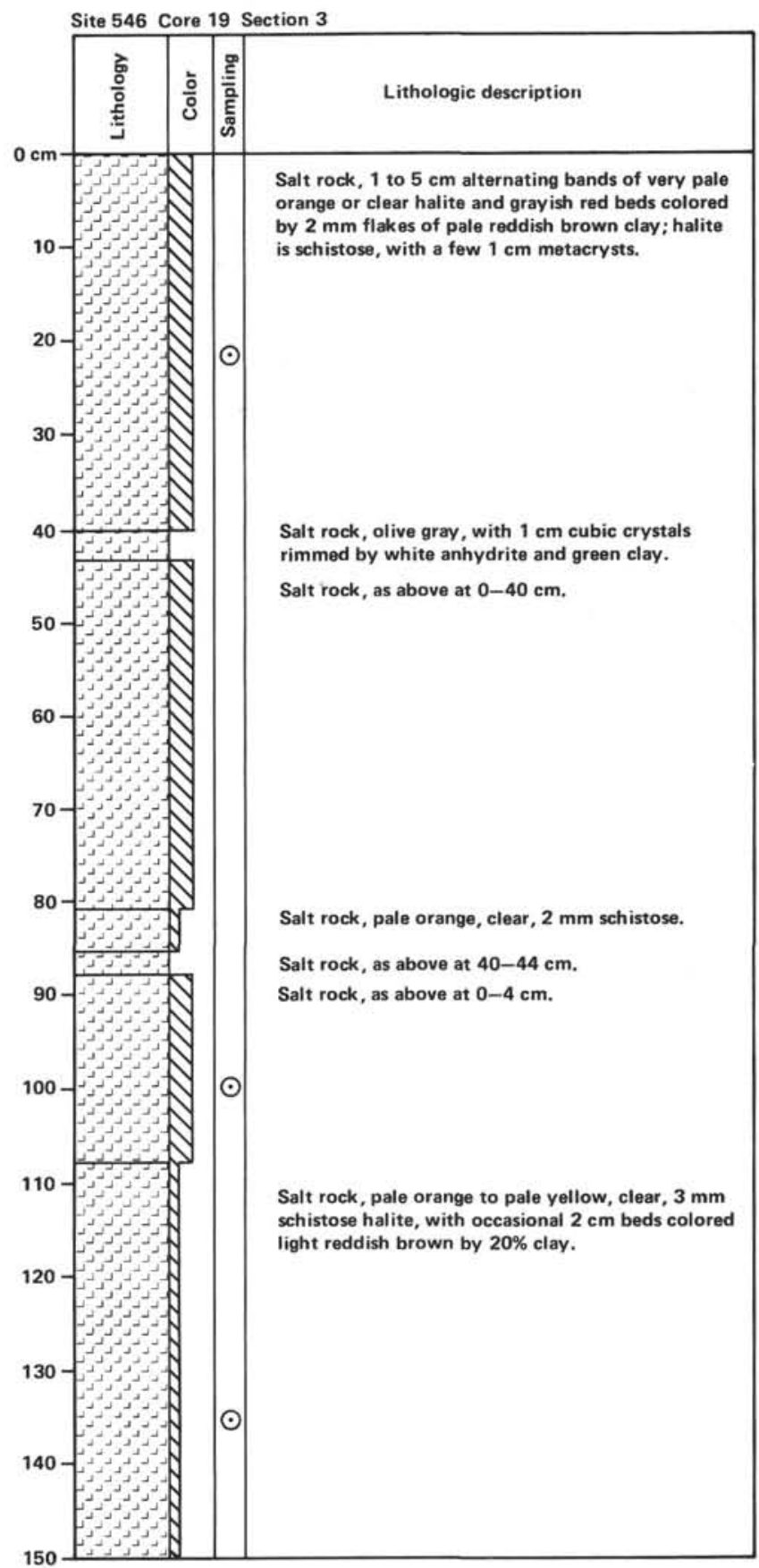


Appendix. (Continued).

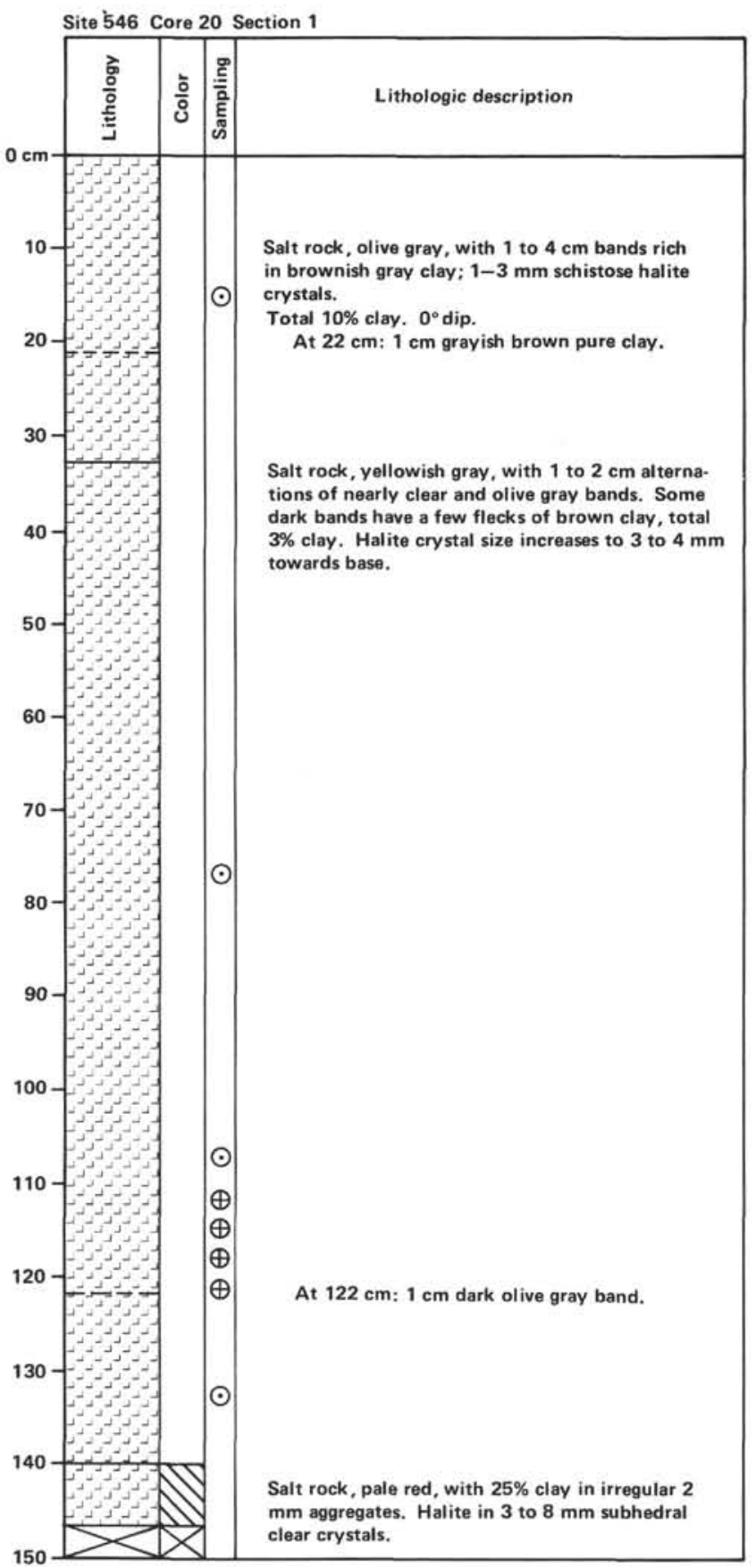

Appendix. (Continued).

Lithologic description
Salt rock, medium brown, 1 to $2 \mathrm{~cm}$ bands of
vellowish gray clear and dark clay-rich bands.
Total $20 \%$ clay.
At $4 \mathrm{~cm}: 2 \mathrm{~mm}$ wispy anhydrite lamina.


Appendix. (Continued).

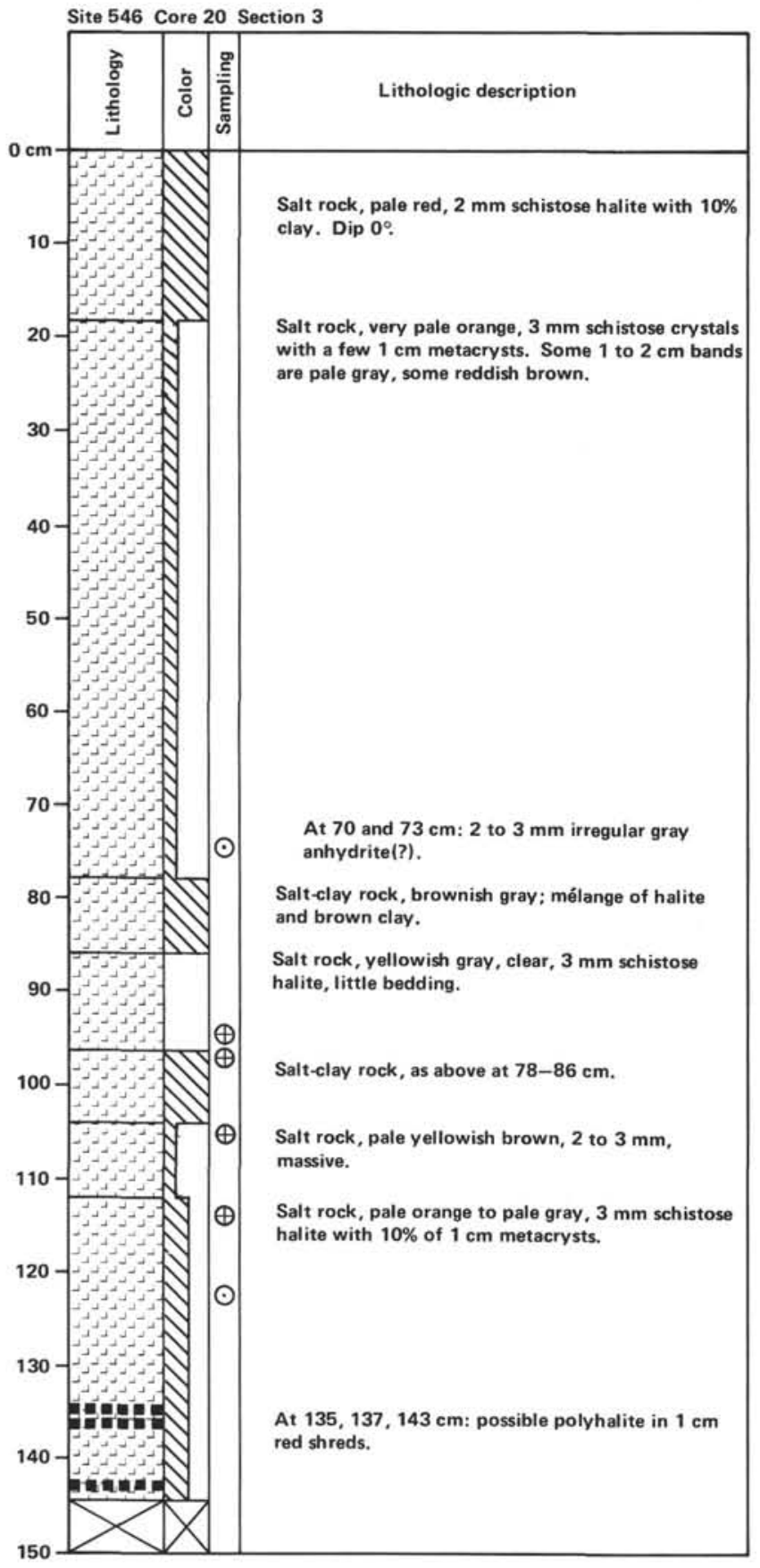

Appendix. (Continued).

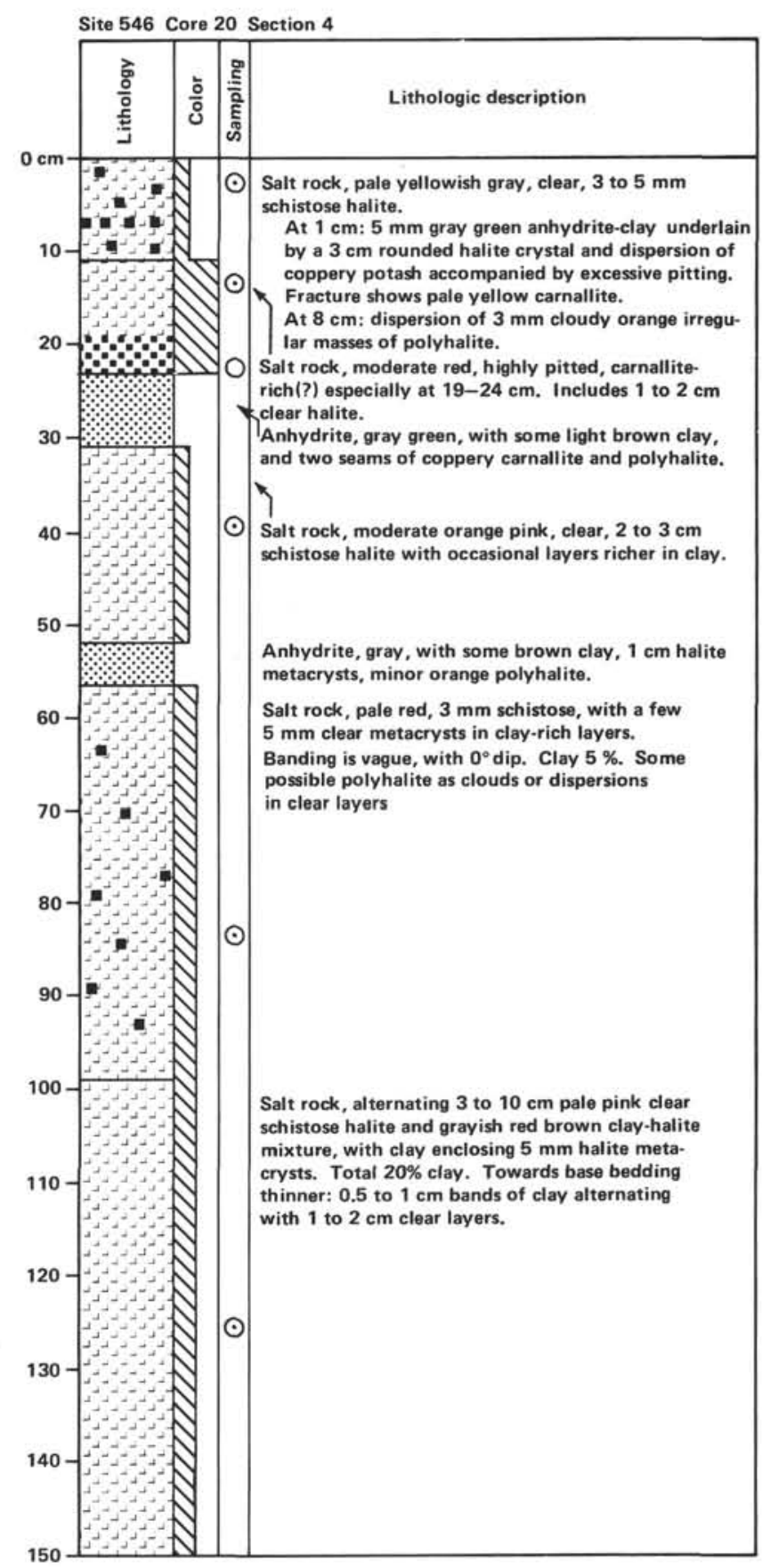


Appendix. (Continued).

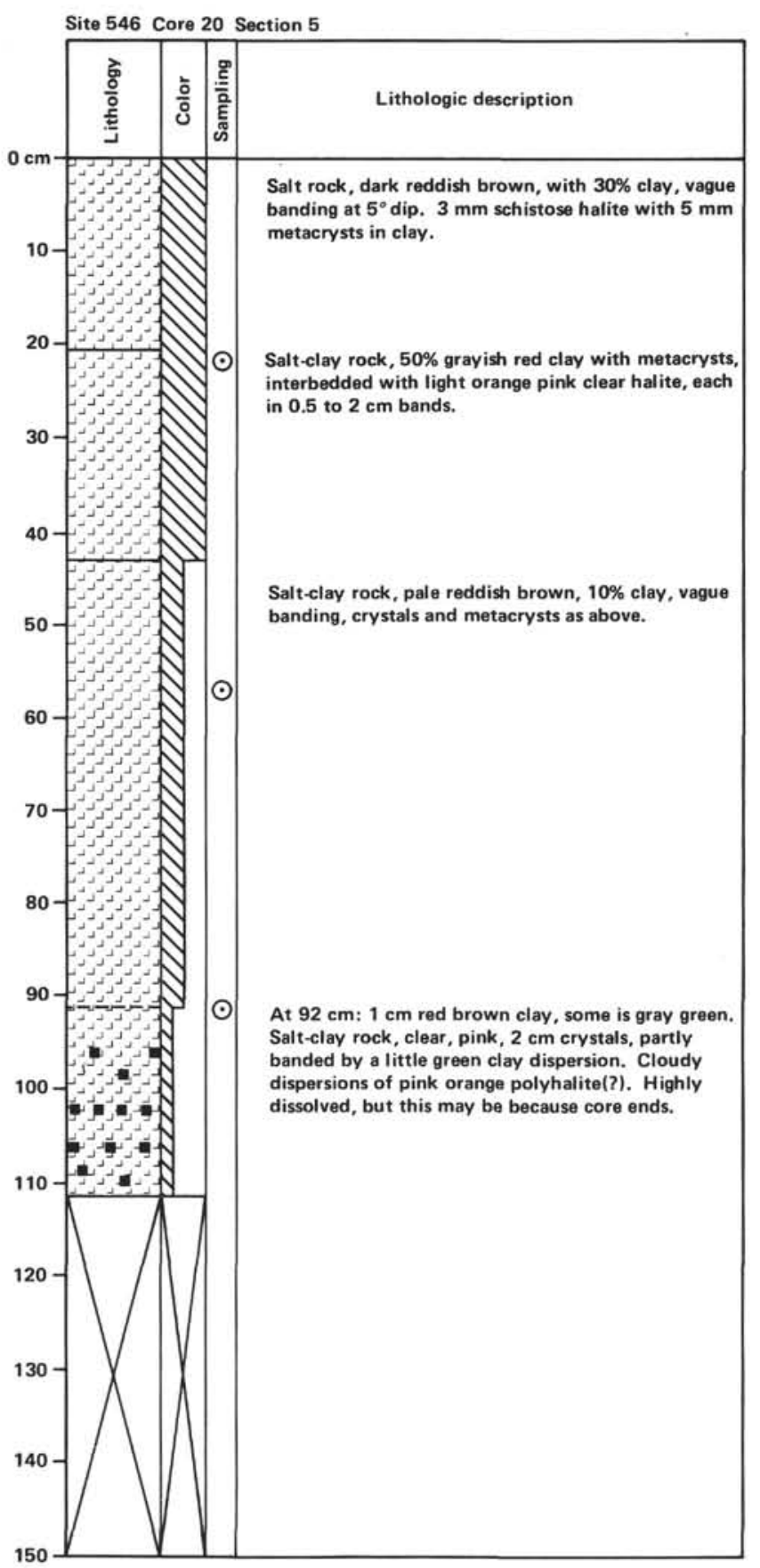

Appendix. (Continued).

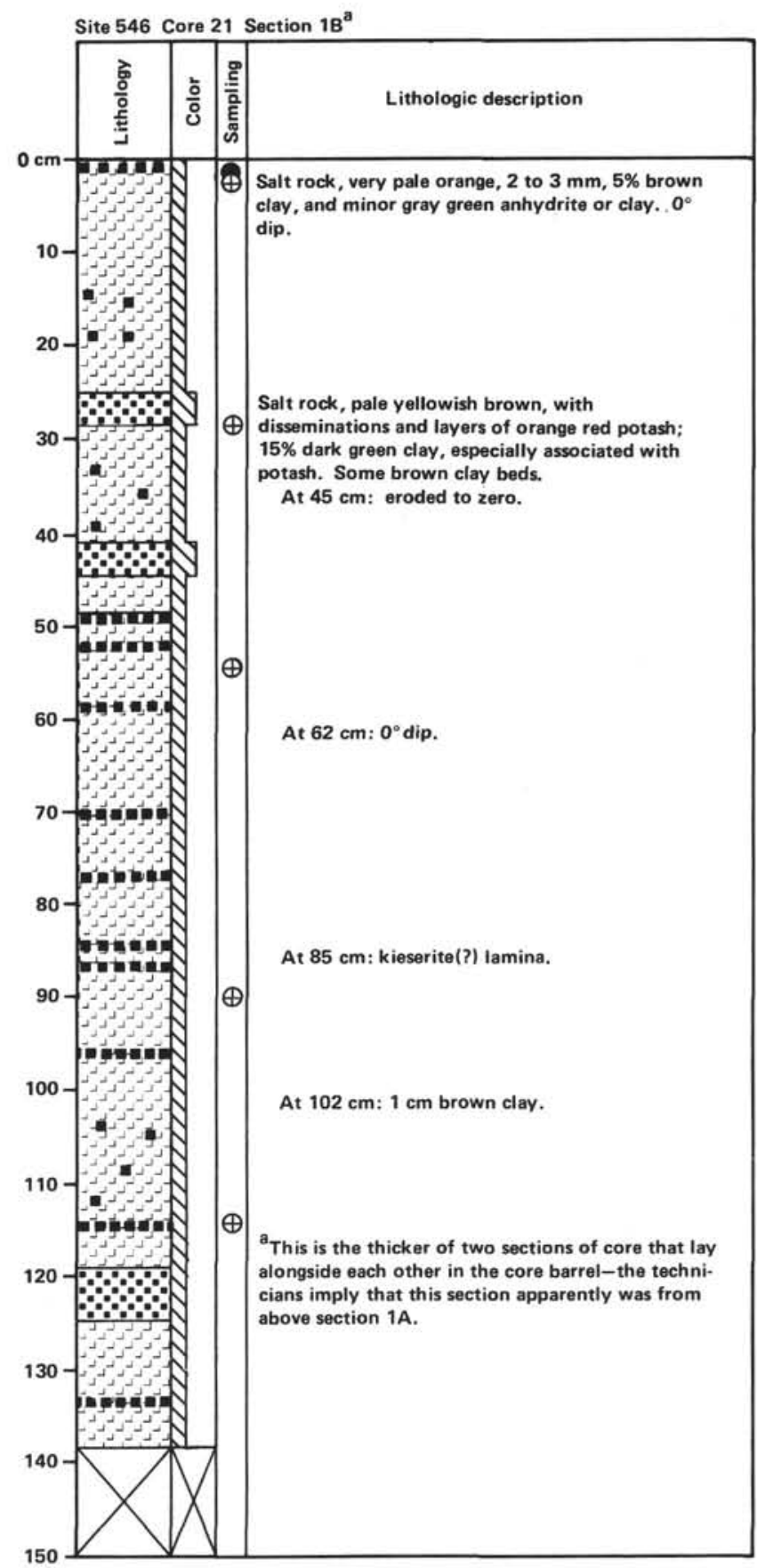


Appendix. (Continued).

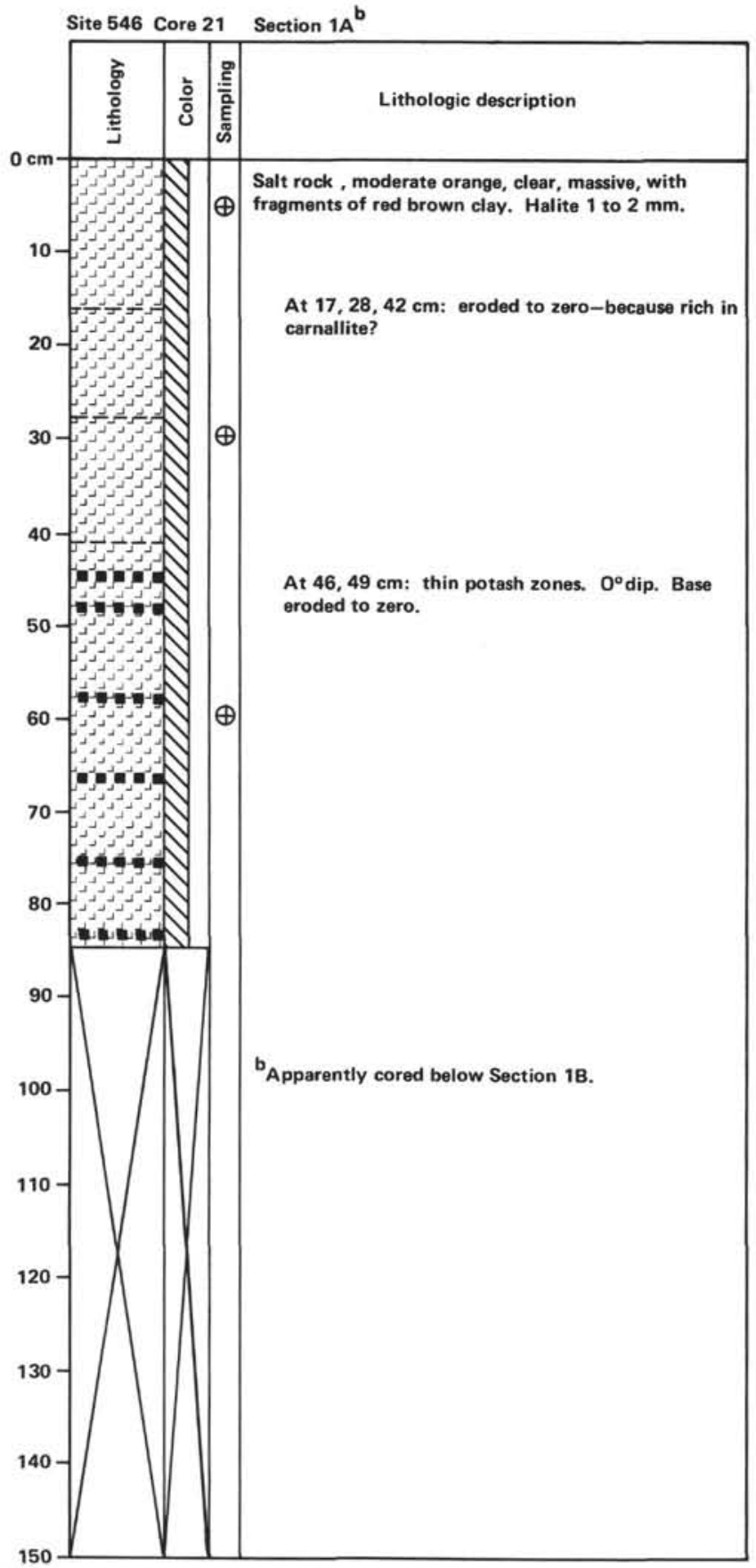

Appendix. (Continued).

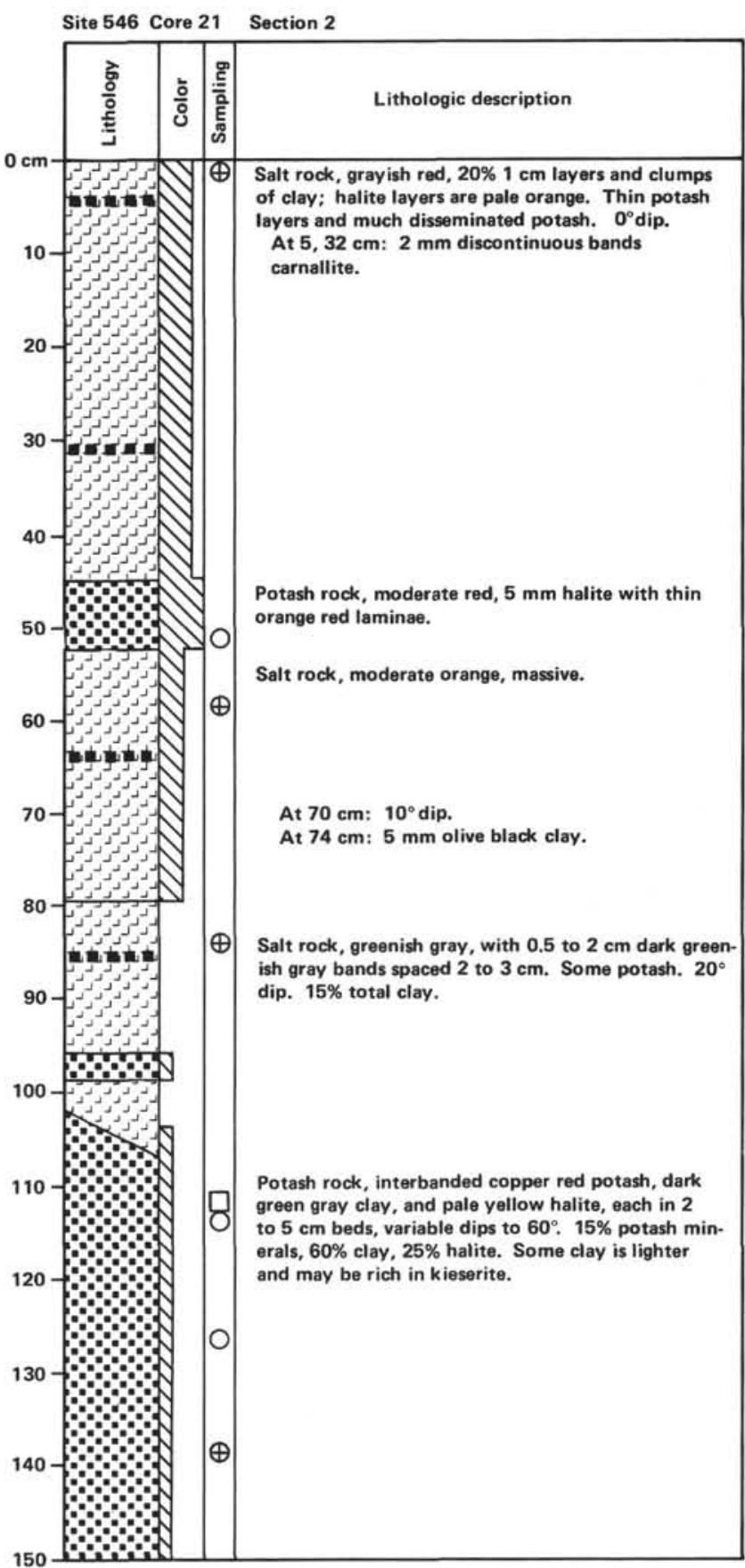


Appendix. (Continued).

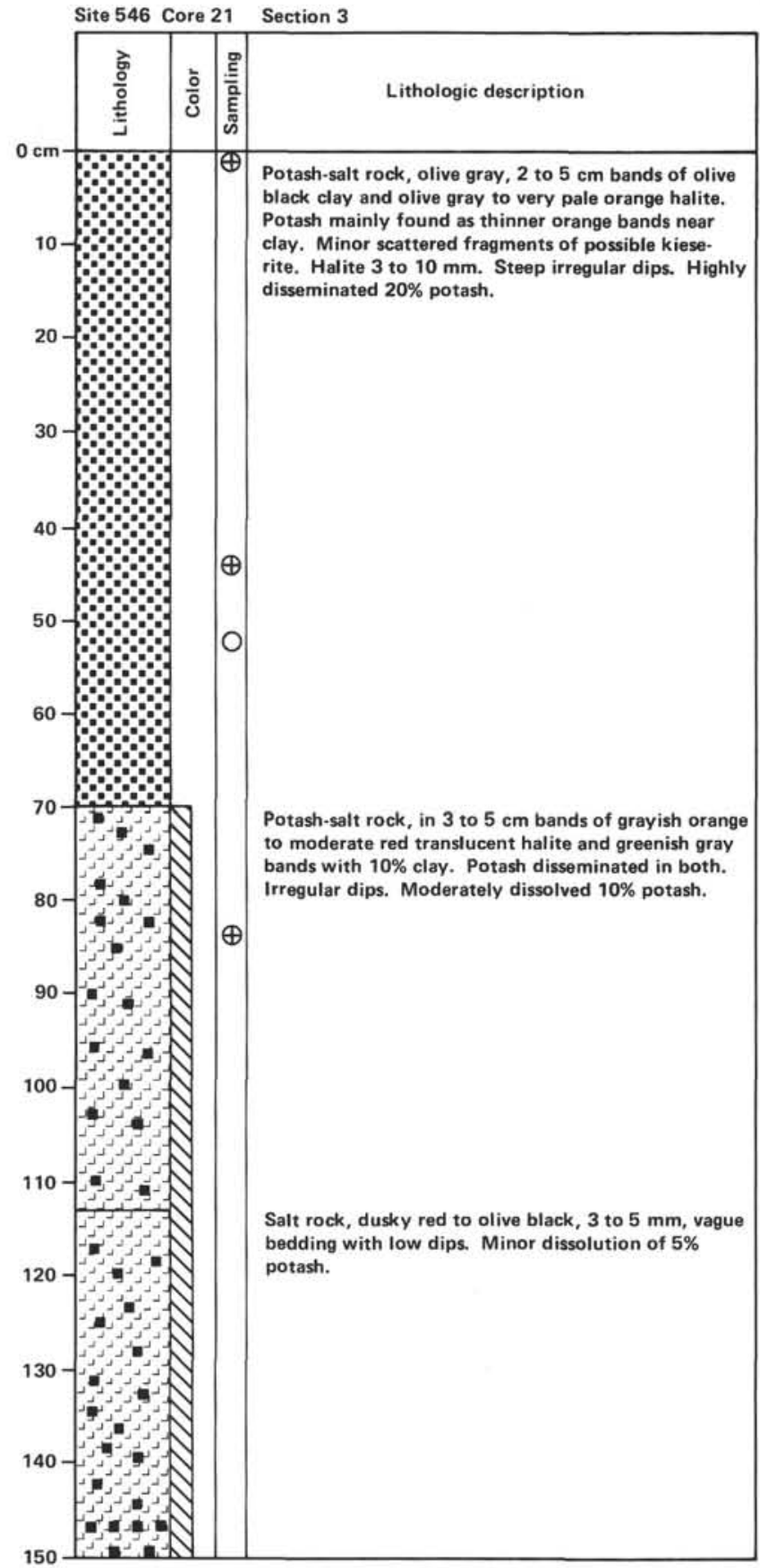

Appendix. (Continued).

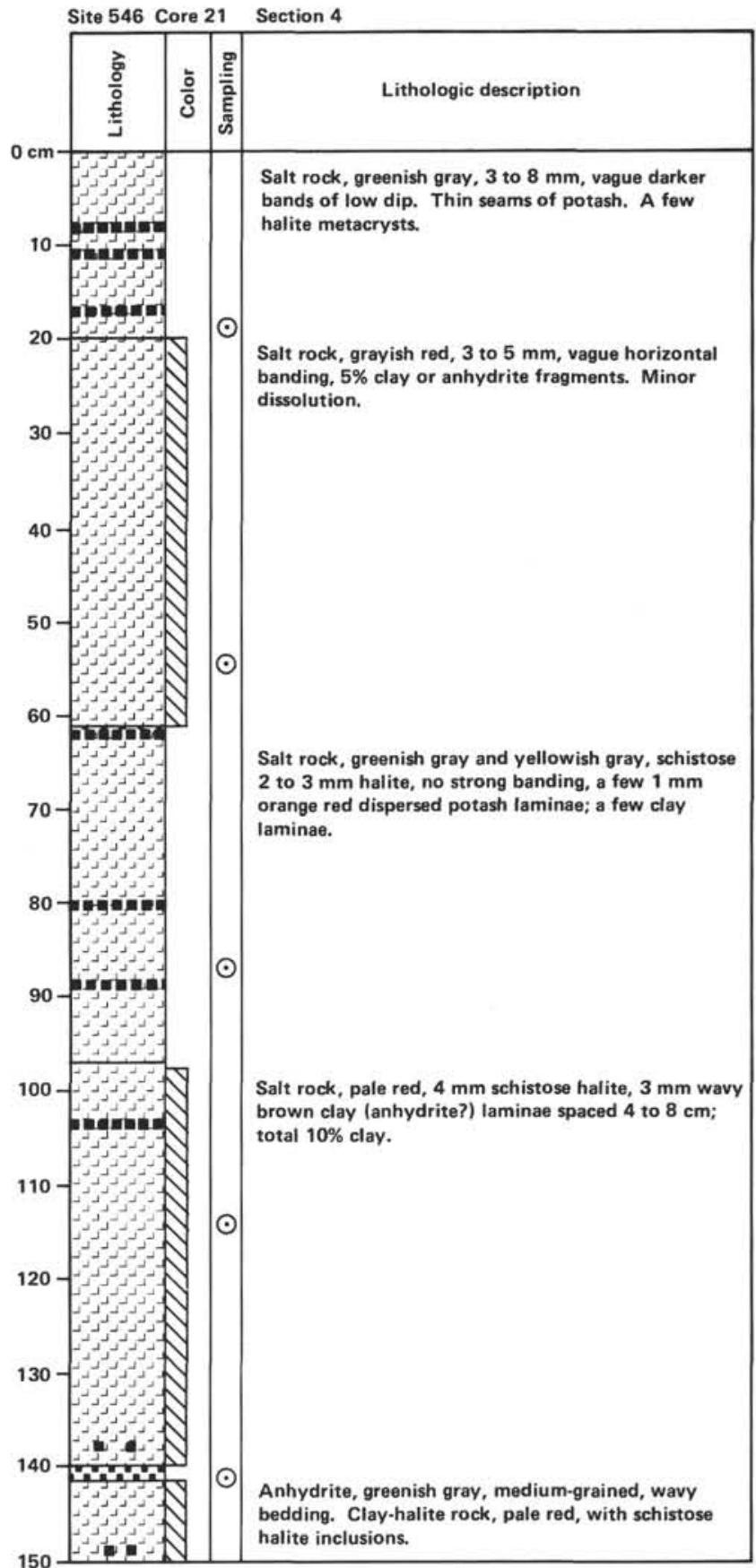


Appendix. (Continued).

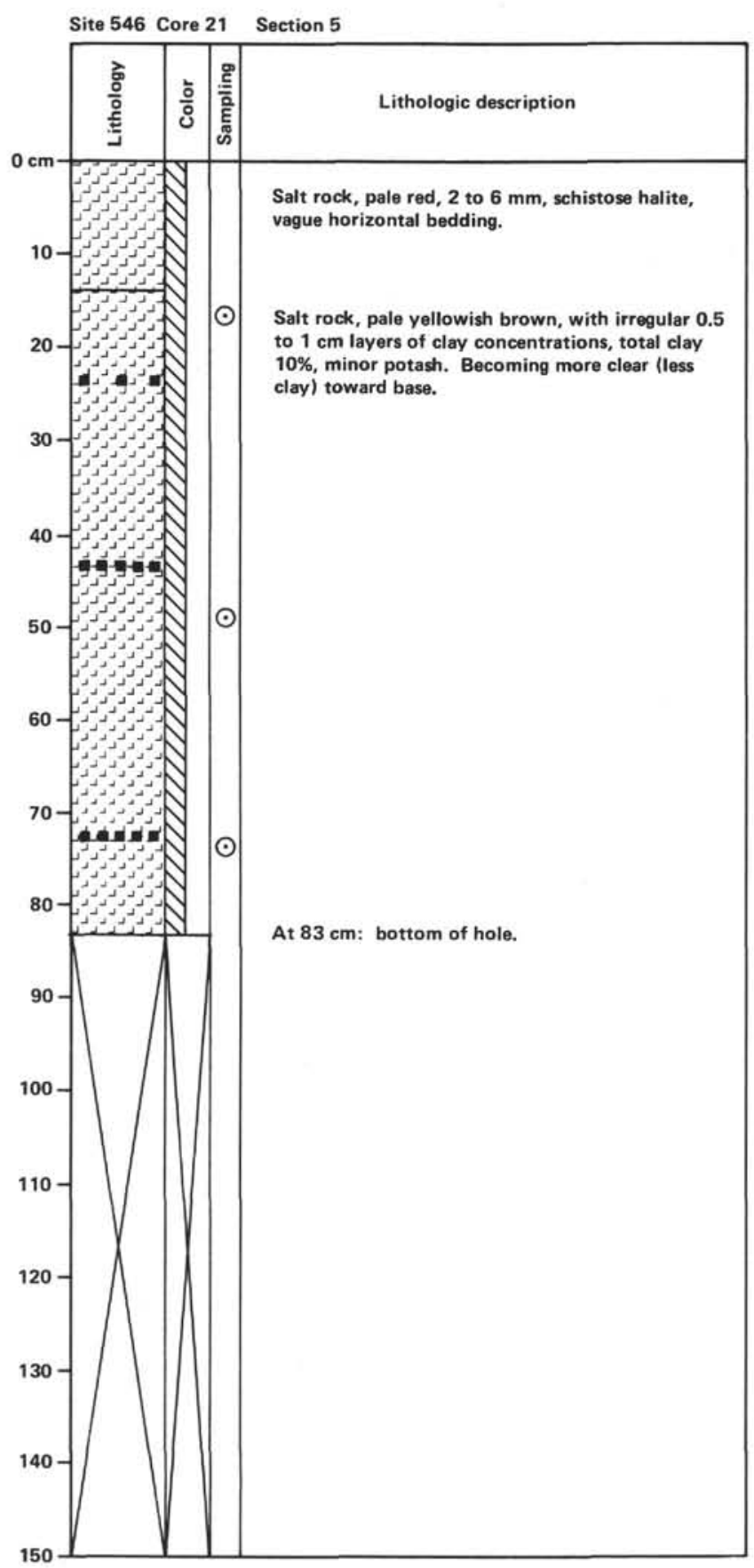



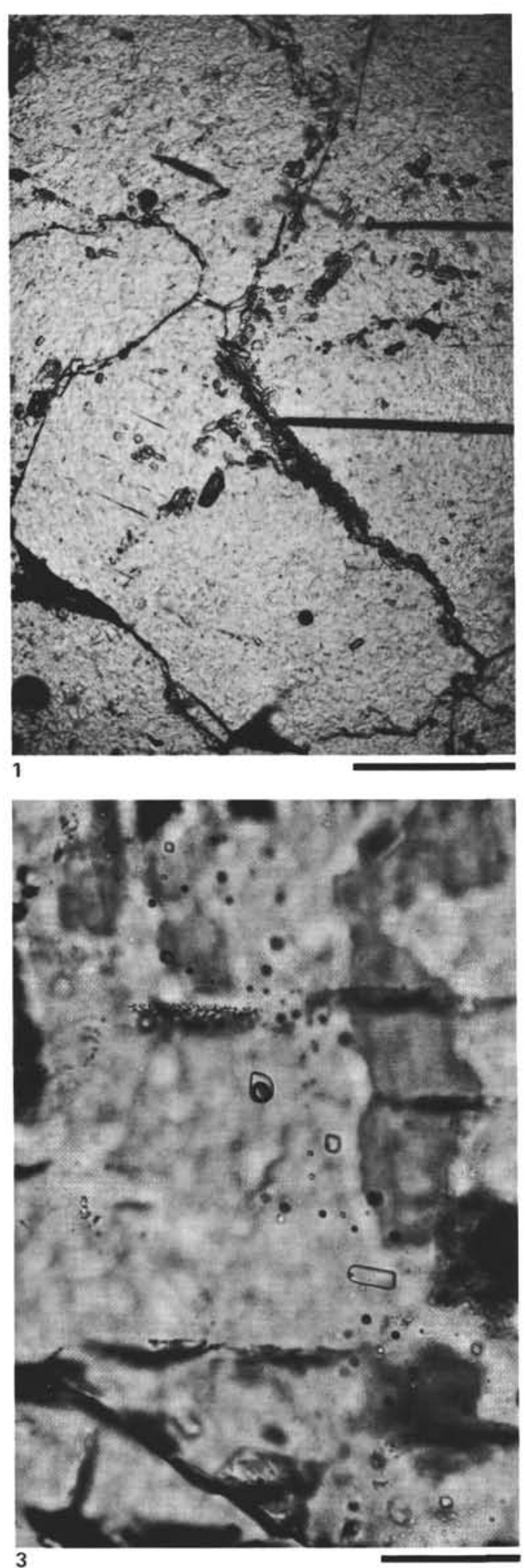

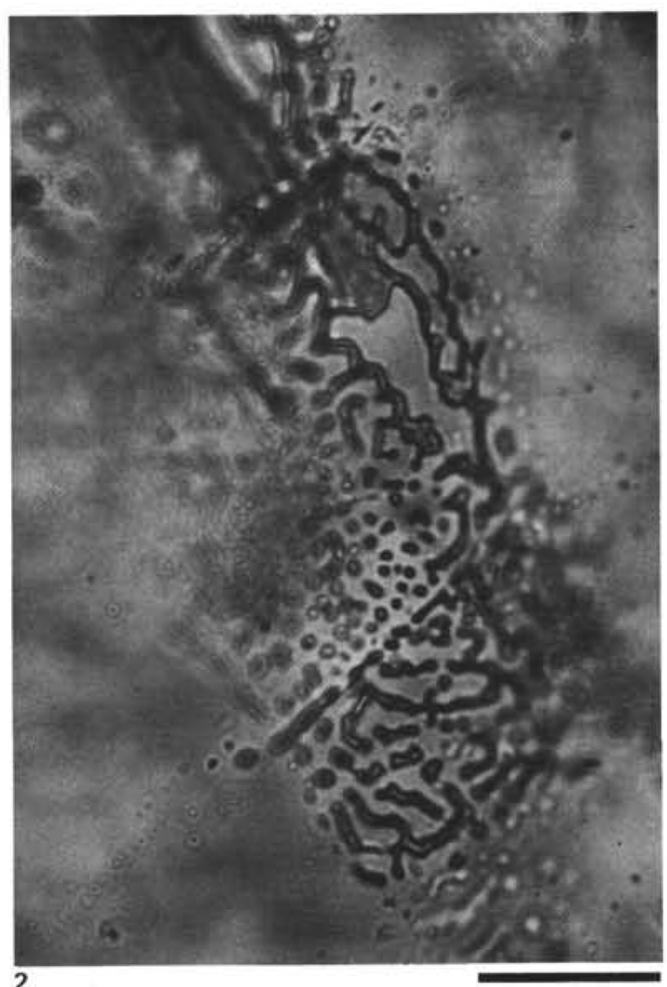

2

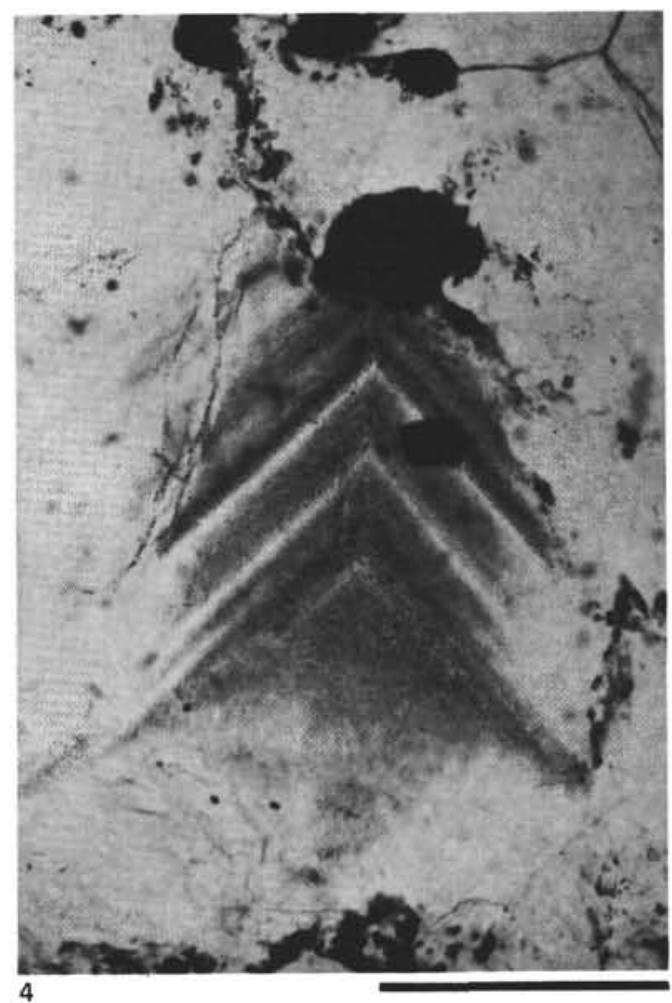

Plate 1. Thin-section photomicrographs of salt rock and its fluid inclusions. 1. Sample 546-18-6, 92-97 cm. Halite rock with aggregates of anhydrite crystals along grain boundaries and also dispersed in halite crystals. The halite grains, distinguished by differing orientations of cleavage, have curved pseudopolygonal boundaries, unrelated to crystallographic directions. This texture is typical of recrystallization in salt domes. Plane parallel light; bar length, $0.5 \mathrm{~mm}$. 2. Sample 546-18-6, 92-97 cm. Labyrinthine fluid inclusions along curving grain boundary between halite grains. Plane parallel light; bar length, $0.03 \mathrm{~mm}$. 3. Sample 546-18-6, 12-17 cm. Negative cube inclusions in halite, with bubbles of varying size suggesting fluid loss. Plane parallel light; bar length, $0.03 \mathrm{~mm}$. 4. Sample 546-19-2, 23-25 cm. Chevron texture (composed of clouds of microscopic fluid inclusions) in halite. This texture results from primary crystallization on the floor of a brine shallow enough to exhibit a diurnal variation of inclusion density as seen here. Black areas are fragments of clay, one of which crosscuts chevron laminae, suggesting deposition on an immediately postdepositional solution surface. Plane parallel light; bar length, $0.5 \mathrm{~mm}$. 

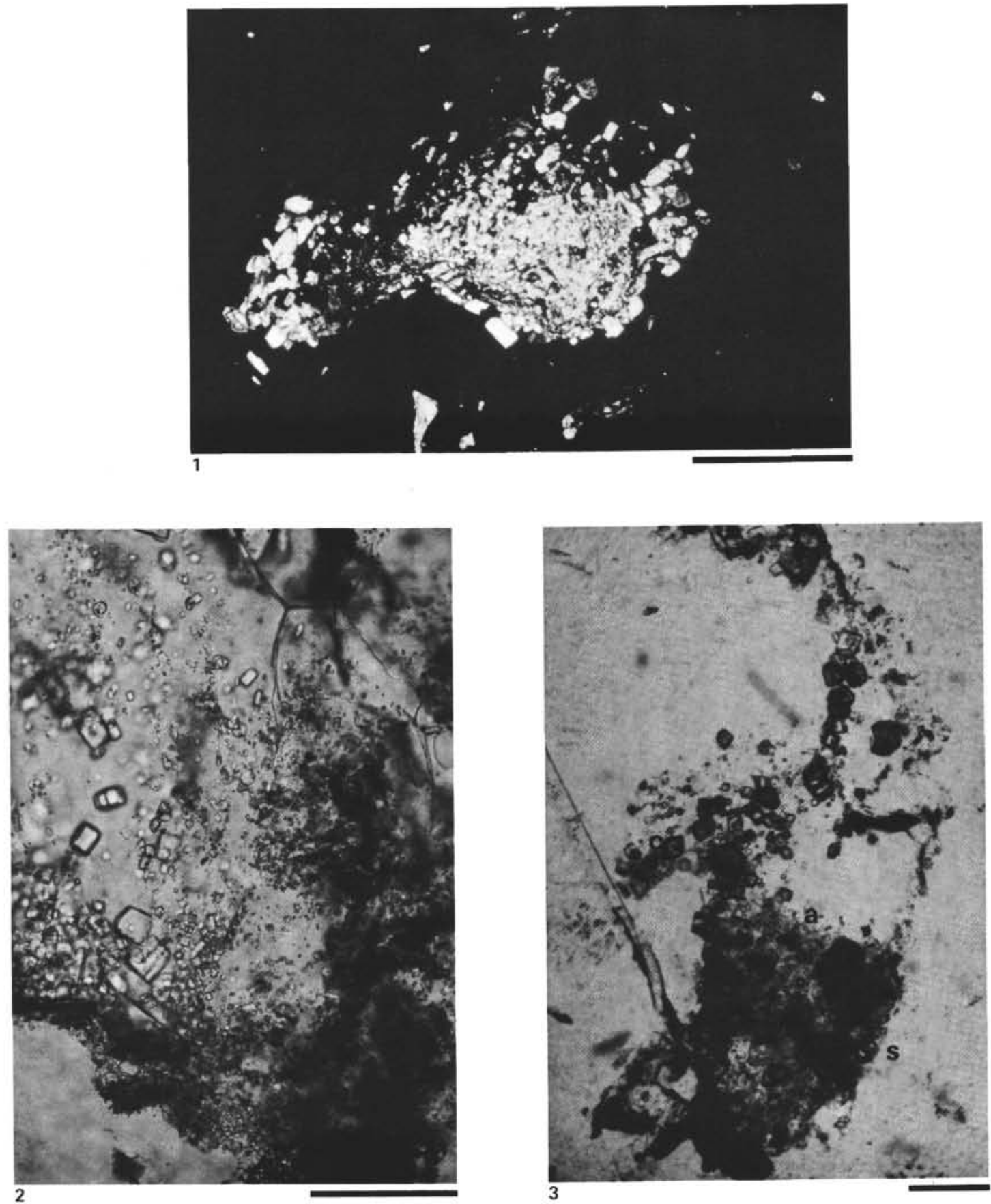

Plate 2. Thin-section photomicrographs of salt rock mineralogy. 1. Sample 546-18-5, 74-77 cm. Micronodule of anhydrite in salt rock. Such texture is very rare in this core. Crossed polars; bar length, $0.5 \mathrm{~mm}$. 2. Sample 546-19-2, 35-38 cm. Anhydrite crystals (white) and clay aggregates ture is very rare in this core. Crossed polars; bar length, $0.5 \mathrm{~mm}$. 2. Sample $546-19-2,35-38 \mathrm{~cm}$. Anhydriar length, $0.2 \mathrm{~mm}$. 3. Sample 546-19-2, $35-38 \mathrm{~cm}$. Salt rock with irregular band of clay (s), anhydrite (a), and dolomite (d). The close association of these minerals is probably primary to original bands or lamellae. Plane parallel light; bar length, $0.2 \mathrm{~mm}$. 

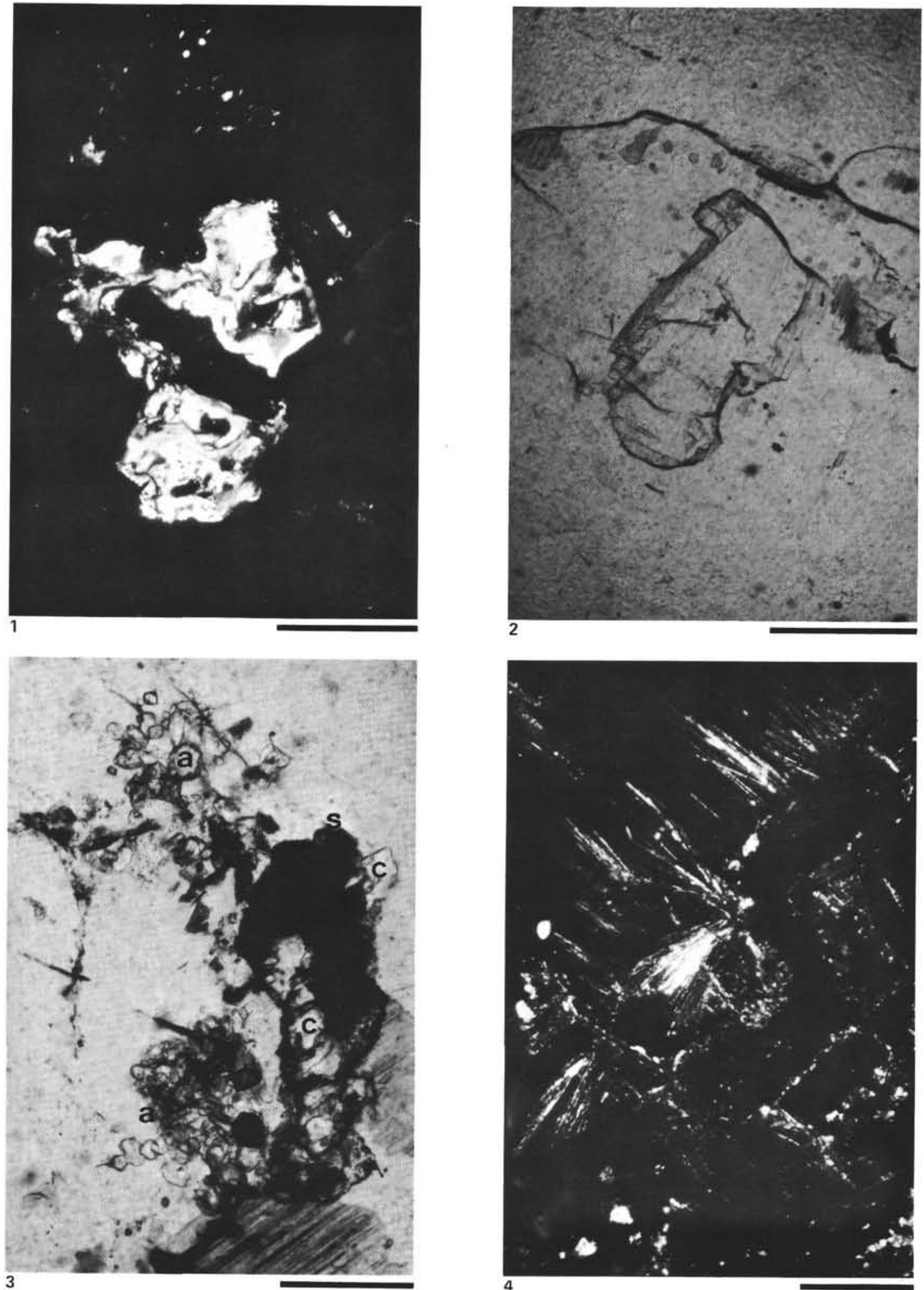

Plate 3. Thin-section photomicrographs of potash mineralogy. 1. Sample 546-18-4, 77-81 cm. Patches of carnallite (white, anisotropic) that extinguish together inhalite (black, isotropic). Crossed polars; bar length, $0.3 \mathrm{~mm}$. 2. Sample 546-18-4, 77-81 cm. Irregular crystal of sylvite in halite. Plane parallel light; bar length, $0.5 \mathrm{~mm}$. 3. Sample 546-18-4, 77-81 cm. Association of clay (s), carnallite (c), and anhydrite (a) as a ragged band in halite (h). Plane parallel light; bar length, $0.3 \mathrm{~mm}$. 4. Sample 546-18-5, 74-77 cm. Radiating needles of length-fast polyhalite growing from cleavages in halite. Crossed polars; bar length, $0.2 \mathrm{~mm}$. 